\title{
Ontogeny and physiology of the digestive system of marine fish larvae
}

\author{
J.L. Zambonino Infante ${ }^{1^{\star}}$, Gisbert E. ${ }^{2}$, Sarasquete C. ${ }^{3}$, Navarro I. ${ }^{4}$, \\ Gutiérrez J. ${ }^{4}$, and C.L. Cahu ${ }^{1}$
}

${ }^{1}$ UMR 1067, Nutrition Aquaculture Génomique des Poissons, IFREMER, BP 70, 29280 Plouzané, France.

${ }^{2}$ Centre d'Aqüicultura, Institut de Recerca i Tecnologia Agroalimentaries (IRTA), Aptat. Correus 200, 43540 Sant Carles de la Ràpita, Tarragona, Spain.

${ }^{3}$ Instituto de Ciencias Marinas de Andalucía. CSIC Polígono Rio San Pedro. Apdo oficial. 11510. Puerto Real. Cádiz, Spain.

${ }^{4}$ Departament de Fisiologia, Facultat Biologia, Universitat de Barcelona, Av. Diagonal, 645, 08028

Barcelona, Spain

* corresponding author : jlzambon@ifremer.fr, tel 33-298224090 fax 33-298224366

\section{Introduction}

The ontogeny of the digestive tract of marine fish larvae has been the subject of many studies these last twenty years. Beyond the scientific interest for such animal species, particularly for developmental aspects, most of these studies aimed to come up with the expectations of commercial hatcheries by reducing the bottlenecks in larvae culture and weaning processes (switch from live preys to compound diet feeding sequence). Consequently, the profile and dietary adaptation of digestive enzymes, the description and histology of the main organs have been extensively studied, when others aspects of the physiology of the larvae digestive tract (gut hormones, intestinal transport...) were poorly investigated and this imbalanced knowledge is showed through this review.

For a long time, it has been hypothesized that marine fish larvae had insufficient digestive enzyme capacity to handle compound diets compared to juvenile fish, and several weaning strategies were built on the supply of exogenous enzymes (Kolkovski, 2001) but were never very conclusive. More recently, it was considered that ontogenetic differences between the larval type and adult type organ function do not mean that larvae face physiological or digestive deficiencies during early life stages. Fish larvae should not be considered as primitive organisms but represent a transitional period in which both ontogeny and growth cause substantial changes in structure, physiology, size and body shape. The basic mechanisms of organ development are similar in all teleosts, even though there are considerable differences regarding the relative timing in the ontogeny. The time in organ development and its associated physiological functions is affected by the general life history of each species and a number of abiotic and biotic factors, such as water temperature, food availability and composition during early life stages. These changes determine the nutritional and physiological performances of a fish, and therefore its ability to deal with challenges during its subsequent life (Fuiman, 1997).

According to these previous considerations, it has been considered determining to take into account the digestive features of the marine fish larvae for formulating compound diets, in the view to promote the larvae growth and facilitate the settlement of an adult mode of digestion (Zambonino Infante et al., 1997; Cahu et al., 2003). The knowledge about the ontogeny of the gastrointestinal tract has gained by the association of different analytical approaches, from classical histology to molecular approaches, including immunohistochemical and biochemical research. These studies have demonstrated that marine fish larvae constitute a very interesting animal model to study the interactions between nutrients (exogenous nutrition) and the developmental processes. Therefore, the potential applications of studies on the ontogeny of the gastrointestinal tract in marine fish larvae go beyond the field of fish aquaculture, .with possible applications to human health (Marza et al., 2005).

This review aims to summarize the informations available on the morphological and functional changes occurring in the main organs of the digestive tract of several species of marine fish larvae, and examine the factors regulating these changes. 


\section{Embryonic development of the digestive tract}

The primordium (clustering of cells from which a part or an organ develops) of the digestive system of fish appears during the embryonic development. Digestive system morphogenesis and differentiation in fish species depends on the type of egg cleavage. Complete or holoblastic cleavage is typical of primitive fish species, such as Acipenseriformes (sturgeon and paddlefish), whereas the incomplete or meroblastic cleavage is typical for Chondrychthyes and Osteichthyes (Kuz'mina and Gel'man, 1998).

In Acipenseriformes, an archenteron or primitive gut is formed by invagination of the blastoderm during the gastrulation. The archenteron cavity communicates with the exterior of the embryo through an opening, the primitive mouth or blastopore. Endodermal cells derived from large macromeres (vegetal hemisphere) and very rich in yolk form the wall of the gut and function as a store of material yolk for growth and development of the embryo and larva, but as the yolk is progressively consumed, they will differentiation into the epithelia lining the intestine and stomach (Dettlaff et al., 1993). In Osteichthyes, all organs including the digestive tract differentiate in the embryonic shield, and the yolk becomes extraembryonic and is surrounded by a periblast. In meroblastic eggs, a thick endoderm string situated on the yolk sac represents the primordium of the gut. No gastral cavity and gastropore is formed. The cavity in the gut appears later due to the migration of endodermal cells.

\section{Post-hatching development of the main organs involved in digestion}

At hatching, the digestive tract appears as a straight and undifferentiated tubular segment laying dorsally to the yolk sac. It is important to note that, in spite of significant differences in the rates of development of organs and systems in bony fish and cartilaginous species, the formation of the digestive tract is completed towards the end of the larval stage and juvenile metamorphosis, while the cytological differentiation takes place earlier than the differentiation of tissue and anatomy (Kuz'mina and Gel'man, 1998). Depending on the species, the rudimentary gut is lined by a pseudostratified or cubic-columnar epithelium with central/basal nuclei and distinctive apical short microvilli. Despite the undifferentiated histological aspect of the gut at hatching, a study at an electron microscopic level of the gut in European seabass and Atlantic cod revealed that, there appear some ultrastructural variations in the epithelial cells lining the anterior, medium, and posterior gut regions (Morrison, 1993; García-Hernández et al., 2001). These cells show lateral or basal lamellar structures associated with mitochondria, which suggests that the gut is involved in osmoregulation processes before the start of the exogenous feeding. The lumen of the gut is narrow with the tendency to widen at both extremes. There are no anterior or posterior openings, since the anus and mouth are not yet differentiated and open to the exterior. During the lecitotrophic stage, the digestive system undergoes further differentiation and the rudimentary alimentary canal becomes segmented into three different anatomical and histological regions: the buccopharynx, oesophagus and intestine.

As most published information on the ontogenetic anatomical, morphological and functional development of the digestive system in fish is focused on teleost species that are important to marine aquaculture; this section is only focused on those species from cold, temperate and warm waters rather than fish as a zoological group. Thus, the description of the ontogenetic development of the digestive tract and accessory glands presented in this section is based on descriptions of the following species: order Gadiformes: family Gadidae, Atlantic cod, Gadus morhua (Morrison, 1993) and, haddock, Melanogrammus aeglefinus (Hamlin et al., 2000); order Perciformes: family Moronidae, European sea bass, Dicentrarchus labrax (García-Hernández et al., 2001); family Serranidae, spotted sand bass, Paralabrax maculofasciatus (Peña et al., 2003); family Sciaenidae, yellow croaker, Psedoscianea crocea (Mai et al., 2005); family Sparidae, common dentex, Dentex dentex (Santamaría et al., 2004), white seabream, Diplodus sargus (Ortiz-Delgado et al., 2003), common pandora, Pagellus erythrinus (Micale et al., 2005) and gilthead seabream, Sparus aurata (Sarasquete et al., 1995); order Pleuronectiformes: family Soleidae, Solea senegalensis, Senegal sole (Ribeiro et al., 1999a) and S. solea, Dover sole (Bouhlic and Gabaudan, 1992); family Paralichthydae, Paralichthys dentatus, summer flounder (Bisbal and Bengtson, 19995) and P. californicus, California halibut (Gisbert et al., 2004a); family Pleuronectidae, Hippoglossus hippoglossus, Atlantic halibut (Luizi et al., 1999) and Pleuronectes ferruginea, yellowtail flounder (Baglole et al., 1997); and family Scopthalmidae, Scopththalmus maximus, turbot (Segner et al., 1994). 


\section{Analytical approaches}

The study of the ontogeny of the gastrointestinal tract in marine fish larvae was mainly based on histological and biochemical approaches. These techniques have allowed to describe most of the morphological and functional changes occurring during the larval period, and since the middle of the nineties the molecular tools provided complementary and essential informations on the structure and functioning of individual genes (mainly those coding for digestive enzymes) expressed in a specific biological process in the gastrointestinal tract.

\section{Biochemical approach}

The small size of marine fish larvae made difficult the direct use of analytical strategies developed for upper vertebrates. Analytical studies on larvae need a great number of individuals in order to get a minimum of biological material compatible with biochemical detection. In addition, only the larvae dissection in segments (Figure 1) have allowed to distinguish different tissues, making easier the purification of particular cell compartments and therefore the spectrophotometric assay of their enzymes or other biological active molecules. As an example, the dissection of separate pancreatic and intestinal segments provided the first quantitative data on pancreatic secretion during larvae development (Pedersen and Andersen, 1992; Cahu and Zambonino Infante, 1994); moreover, the purification by simple centrifugations of the brush border membrane of enterocytes from intestinal segment allowed to distinguish membranous enzymes from cytosolic ones, gave the first information concerning the intestinal maturation in developing fish larvae (Cahu and Zambonino Infante, 1994). Table 1 summarized the most commonly (and pratical) assays for pancreatic and intestinal enzymes.

Recent systematic and global analysis of gene expression (genomics) in cells or tissues allowed to identify genes involved in a global physiological response to a particular nutritional or environmental situation; these techniques have just begun to be used in some fish models (zebrafish, fugu, trout) but the new resulting information will be, without any doubt, essential for most of the other fish species.

\section{Histological approach}

Larvae may be fixed in Bouin's solution or $10 \%$ neutral buffered formalin $(0.1 \mathrm{M}$ sodium phosphate, $\mathrm{pH} 7.2$ ) for 48 hours minimum. Once the tissue has been fixed, it must be processed into a form in which it can be made into thin microscopic sections. The usual way this is done is with paraffin but many other substances (synthetic resins) are also used. The technique of getting fixed tissue into paraffin is called tissue processing. The main steps in this process are dehydration and clearing. Wet fixed tissues (in aqueous solutions) cannot be directly infiltrated with paraffin. First, the water from the tissues must be removed by dehydration. This is usually done with a series of alcohols $70 \%$ to $95 \%$ to $100 \%$. Other dehydrants can be used, such as acetone or dioxane. The next step is called "clearing" and consists of removal of the dehydrant with a substance that will be miscible with the embedding medium (paraffin). The commonest clearing agent is xylene. Finally, the tissue is infiltrated with the embedding agent, almost always paraffin. The above-mentioned processes are almost always automated for the large volumes of routine tissues processed. Automation consists of an instrument that moves the tissues around through the various agents on a preset time scale.

Some tissues in late larvae and early juveniles contain calcium deposits which are extremely firm and which will not section properly with paraffin embedding owing to the difference in densities between calcium and paraffin. This calcium must be removed prior to embedding to allow sectioning. A variety of agents or techniques have been used to decalcify tissue, such as mineral acids, organic acids (formic acid), EDTA, and electrolysis (Luna 1967; Humason 1972; Gabe 1976).

Once the tissues have been embedded, they must be cut into sections with a microtome and placed on a slide. After tissue sectioning, samples should be staining, thus the embedding process must be reversed in order to get the paraffin wax out of the tissue and allow water-soluble dyes to penetrate the sections. Therefore, before any staining can be done, the slides are deparaffinised by running them through xylenes (or substitutes) to alcohols to water (Martoja and Martoja-Pierson, 1970). There are no stains that can be done on tissues containing paraffin. The staining process makes use of a variety of dyes that have been chosen for their ability to stain various cellular components of tissue. The routine stains are those of Harry's Haematoxylin/Eosin (H-E), Harry's Haematoxylin/VOF (light green-orange G-acid fuchsin) or Haematoxylin/VOF Type-III G.S (Gutiérrez, 1967; Sarasquete and Gutiérrez, 2005).

For the histochemical study of enzymes and lipids, fresh tissue is rinsed in a cryoprotectant $(2.1 \mathrm{M}$ sucrose in phosphate buffered saline, PBS) for 15-60 min, depending on sample size, frozen and 
mounted in an embedding medium, before being sectioned from 6 to 8 microns with a cryostat from 27 to $-70^{\circ} \mathrm{C}$.

The most common histochemical reactions used to detect proteins, carbohydrates, lipids and enzymes are summarised in Tables 2-5 (Barka and Anderson, 1967; Martoja and Martoja-Pierson, 1970; Lodja et al., 1979; Culling et al., 1985; Pearse, 1985; Bancroft and Stevens, 1990; Kiernan, 1999). The following list of procedures and histochemical reactions is not exhaustive and more staining reactions and procedures for specific compounds may be found in the above-mentioned literature.

\section{Immunohistological approach}

To study the appearance of endocrine cells during fish development, histological and immunohistochemical approaches are the most often used. By means of the appropriate antibodies it is possible to determine the localization of immunoreactive cells for different hormones in serial sections of those region studied. Studies by García- and Agulleiro (1992) and Reinecke et al., (1997) provide excellent examples of these techniques. However, the resulting data are highly dependent of the specificity of the antibody utilized. Indeed, this is critical for some molecules that share parts of the structure, consequence of its common phylogenetic origin; such is the case of several of the gastro entero pancreatic (GEP) peptides (insulin and insulin growth factors (IGFs), Glucagon and glucagons like peptides (GLPs), CCK and gastrin, etc.). The antibodies rised against fish peptides are scarce. Kurokawa et al. (2000) utilized anti insulin serum against barfin flounder (Verasper moseri) insulin II and García-Hernández et al. (1994) utilized porcine insulin (Immunonuclear 561) or bonito insulin (Dr. Gutiérrez, J.) antiserum. GroPep offers a variety of IGF-I (PAF, PAF-AGU) antibodies that are specific for different fish species (barramundi, bream, salmon, tilapia, trout, tuna); Reinecke et al. (1997) obtained good results by using human antibodies raised against human IGF-I. Plasma glucagon levels were determined in different species (trout, carp, tilapia, European sea bass, gilthead seabream, dogfish) using the antiserum $30 \mathrm{~K}$ of R.H. Unger and the K5563 from Novo against human glucagon. García-Hernández et al. (1994) utilized for sea bass the antibody Immunonuclear 748 against bovine/porcine glucagons; these authors also detected Somatostatin 25 using the antibody obtained by Dr.E M. Plisetskaya against the salmon peptide and somatostatin 14 by using the antibody from Immunonuclear 562. R.E. Chance obtained the antibody R-140-146-17, which can detect PP in fishes and there is also the antibody 842 of Dr. E.M. Plisetskaya against salmon PP. Kurokawa et al. (2000) utilized an antiserum raised against a fragment (CCK-10) from Japanese flounder to detect CCK in this species and García-Hernández et al. (1994) used human antibodies from Immunonuclear (17230) to locate CCK cells and Gastrin cells from Milab (R783511-2). Studies utilizing optical microscope, can be enhanced by electron microscopy and García et al. (1994) for example, analyzed the ultra structure of the endocrine pancreas cells in sea bass larvae. Immunoelectromicroscopy offers yet another approach, one permiting the identification of cell ultra structure of the cell that produces the specific peptide.

\section{Buccopharynx}

The histological organization and development of the buccopharynx in larvae is quite similar among marine teleost species. At mouth opening, the pharynx is lined by a simple monostratified squamous epithelium, surrounded by connective tissue and a circular muscle layer. In common dentex and Atlantic cod, chloride cells involved in osmoregulation processes are scattered throughout the buccopharyngeal epithelium. Coinciding with first feeding in Dover sole and summer flounder, the tongue develops progressively as a thickening of the mouth floor, and consists of a stratified squamous epithelium. The ontogeny of buccopharyngeal goblet cells varies among species (Table 6). In Dover sole, first functional goblet cells and taste buds appear at the onset of exogenous feeding, whereas in California halibut, yellowtail flounder, summer flounder and common pandora, they appear much more lately. The histochemical characteristics of buccopharyngeal goblet cell contents also varies depending on the species, e.g. goblet cells in California halibut larvae secrete a combination of

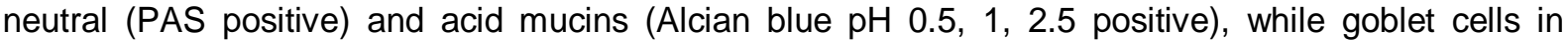
yellowtail flounder and Dover sole only contain acid glycoproteins (Figure 2).

The development of teeth also varies among species. Often larval dentition is different from that of the adult, and is used for grasping rather than masticating the prey, which can often be seen whole in the digestive tract. Usually, teeth develop in the areolar connective tissue underlying the buccopharyngeal epithelium (Figure 3)., and pharyngeal teeth appear before those in the mandible 
(Tanaka, 1971). In common pandora and summer flounder, mandibular and maxillar teeth are detected earlier than those located in the pharynx, which will erupt into the pharyngeal cavity during larval metamorphosis. In some species such as turbot (Cousin and Laurencin, 1985), it has also been reported that the dorsal pharyngeal teeth appeared before the ventral.

As larval development proceeds, the degree of stratification of the epithelium, as well as the number of goblet cells and taste buds increases in the buccopharyngeal mucosa. At the end of the larval stage, buccopharyngeal papillae, which are involved in food predigestion and transport processes, appear at the posterior region of pharynx in California halibut and yellowtail flounder (Figure 3).

\section{Oesophagus}

In most teleost marine species, the oesophagus starts to differentiate soon after hatching, just before mouth opening and the onset of exogenous feeding. At this stage, the oesophagus is a short and narrow duct lined by a stratified or pseudostratified epithelium, connecting the buccopharyngeal cavity with the anterior opening of the intestine or stomach anlagen. During the lecitotrophic stage and just before mouth opening, columnar cells with light cytoplasm and posteriorly directed cilia have been observed in the oesophagus of common dentex and Atlantic cod, but not in that of other studied species so far. These cells, which are uncommon in adult specimens, have been related to water transport through the digestive tract and osmoregulation processes (Tytler and Blaxter, 1988). During the transition to exogenous feeding, the oesophagus elongates and shows prominent longitudinal folds similar to the adults (Figure 4). A loose connective tissue makes up the fold axis and the thin layer that surrounded the epithelium. An external circular layer of striated muscle cells surrounds the oesophageal mucosa and completes the oesophagus wall. The epithelium that lines the oesophagus in larvae is similar to adults, consisting of a simple or stratified epithelium of cuboidal cells in most of described species, such as European seabass, white seabream, summer flounder, Dover sole, Senegal sole and California halibut (Figure 5), whereas in common dentex, yellow croaker and yellowtail flounder it is constituted by a single layer of columnar cells. Posterior to the oesophagus there is a transitional region, where epithelial cells have few microvilli, then the digestive tract slightly widens to form the future stomach, which differs from the juvenile and adult stomach in not yet having gastric glands (Figures 6). It has a mucosa consisting of a simple cuboidal to columnar epithelium with microvilli. The transition from the oesophagus to the stomach is evidenced by the complete disappearance of goblet cells and by the substitution of the stratified or simple oesophageal epithelium into a simple columnar epithelium in the stomach. The appearance of first functional goblet cells scattered among the epithelial cells of the oesophagus varies among species. In soleids (Dover sole and Senegal sole) and yellowtail flounder, goblet cells are detected coinciding with mouth opening and the onset of exogenous feeding, whereas in turbot, California halibut, gilthead seabream, European seabass, white seabream, Atlantic cod and haddock goblet cells are detected at latter stages of development (Table 6). Histochemical studies reveal that there also exist differences in the content of mucosubstances of goblet cells among species. Histochemical double-staining techniques with Alcian blue and PAS dyes show in California halibut and white seabream that buccopharyngeal and oesophageal goblet cells produced a combination of neutral (PAS positive) and acid glycoproteins with sialic acid residues (Alcian blue pH 2.5 and 0.5 positive), being neutral glycoconjugates detected earlier than acid mucins (Figures 7), while neutral mucosubstances were not observed in Dover sole, Senegal sole and yellowtail flounder, whose oesophageal mucous cells only contained acid glycoproteins (Figure 8). Goblet cells are common components in the digestive mucosa of larvae and adult fish (Domeneghini et al., 1998). In different vertebrates including fish, these cells are involved in transport, absorption and protection processes of the gut. In fish, mucosubstances produced by buccopharyngeal and oesophageal goblets cells play an important lubricant role due to the lack of salivary glands, protecting the digestive mucosa from abrasion that feed particles may produce (Scocco et al., 1998). Mucosubstances have been described as also having a protective role, the presence of sialic acid residues in mucous prevented viruses from recognizing their receptor determinants and also preserved the mucosa from the attack of sialidase produced by bacteria (Zimmer et al., 1992). Variability in staining within a given goblet cell could be attributed to a temporal sequence in the mucus biosynthesis. The coexistence of neutral and acid glycoconjugates may indicate a cell differentiation with progressing development. As Sarasquete et al. (2001) reviewed in different fish species, PAS-positive goblet cells represent an early developmental stage, when the cells are producing mainly neutral glycoproteins. According to Els and Hennerberg (1990), the biosynthesis of mucin glycoconjugates includes at least two post-transcriptional modifications of the 
secretory protein; firstly, the glycosilation of the protein followed by modifications of the sugar moiety. Those cells that did not stain with PAS contained only proteins; goblet cells stained with PAS may be related to the stage when the cell is producing mainly glycoproteins. These cells stain with Alcian blue (pH 2.5) when glycoproteins are carboxylated, and the presence of sulphated glycoproteins (Alcian blue $\mathrm{pH}$ 0.5) coincides with the stage when sulphated groups are conjugated to the glycoprotein.

\section{Stomach}

\section{Anatomic and morphological development}

Although in many species an incipient stomach is distinguished soon after hatching at the transition between the oesophagus and the intestine, the stomach is the latest organ of the digestive system to differentiate. At this stage, the stomach is composed of a cluster of cuboidal to columnar epithelial cells with a subepithelial connective layer, and surrounded by circular layer of musculature and a thin tunica serosa. Some fish species, such as cyprinidae, are stomachless all along their life. For the others, stomach not present at hatching develops during the first weeks of life (Figure 9). As the larva grows, the mucosa of the stomach develops and becomes folded. Epithelial cells with a thin granular cytoplasm gradually elongate and these columnar epithelial cells show an oval nucleus in either basal or central position and short microvilli in their apical border. This epithelium that lines the gastric mucosa folds transversally and forms the gastric pits, where the first gastric glands will differentiate. The development and functionality of the stomach is mainly related to the differentiation of gastric glands improving mechanical and enzymatic digestion of food. Stomach and pyloric caeca formation have been associated with the transition from larva to juvenile (Tanaka, 1971; Govoni et al., 1986), and this process of metamorphosis presents important inter-specific differences (Table 7). The stomach is usually estimated as fully developed when gastric glands are present, and three histologically and anatomically different regions are distinguished: cardiac, fundic and pyloric (Figure 10). The cardiac region is the anterior part of the stomach and possesses several longitudinal mucosal folds lined by a simple short ciliated columnar epithelium with basal nuclei but devoid of goblet cells. The fundic region is lined by a simple tall ciliated columnar epithelium. The mucosa of this region contains a large number of simple tubular gastric glands surrounded by a thin layer of connective tissue. These glands are composed of one cell type, named by most authors as oxyntopeptic cells (Ostos-Garrido et al., 1993), that secrete both hydrochloric acid and enzymes, and are similar to those described for lower vertebrates (Smit, 1961) (Figure 11). Histochemical studies reveal that gastric glands contain proteins rich in different aminoacids, such as tyrosine, arginine and tryptophan suggesting the presence of enzymatic precursors such as pepsinogen or digestive enzymes. Gastric secretory cells have a PAS-positive apical border, and their secretory products are rich in neutral mucosubstances (magenta, PAS positive) (Figure 12). Gastric gland secretions, pepsinogen and hydrochloric acid, provide preliminary extracellular protein digestion followed by membrane transport, which replaces the less efficient processes of pinocytosis and intracellular digestion of proteins (Govoni et al., 1986). The pyloric or posterior region of the stomach is relatively short, lined by a short ciliated columnar epithelium and its folded mucosa does not contain gastric glands. The wall of the stomach is composed of a submucosa with connective fibers, some blood vessels, circular muscle fibers, and a thin serosa with basophilic squamous cells. The stomach is separated from the intestine by the pyloric sphincter (Figure 10). Inter-specific differences in the location of gastric glands of fish larvae exist. Gastric glands are normally detected in the cardiac stomach of most studied species. In yellowtail, summer flounder, turbot and Dover sole (Veggeti et al., 1999), gastric glands are located in the fundic region, whereas in Atlantic cod and Senegal sole gastric glands are observed in both gastric regions (Morrison, 1993; Arellano et al., 2001). The gastric mucosa secretes a large quantity of neutral glycoconjugates (Figure 12) that serve, as in higher vertebrates, to protect the epithelium of the stomach from auto digestion processes caused by hydrochloric acid and enzymes produced in gastric glands. The positive-PAS reaction observed on the surface of gastric epithelial cells resembles that seen in the striated border of intestinal enterocytes. This may indicate nutrient absorption occurring in the stomach. In fact, the presence of neutral mucins in the stomach has been related to the absorption of easily digestible substances such as disaccharides and short-chain fatty acids (Grau et al., 1992). Microvilli observed in cardiac and pyloric regions of the stomach probably assist in the distribution and maintenance of the abundant mucous coat and assist the digestive musculature in moving ingested food particles. 


\section{Biochemical description of development}

This organ normally begins the protein digestion with gastric juice containing pepsin and $\mathrm{HCl}$. In larval stages, gastric secretion progressively rises from the fourth post-hatching week in temperate species such as sea bass (Zambonino Infante and Cahu, 1994), and this developmental stage coincided with the histological detection of gastric glands (Walford and Lam, 1993). The appearance of gastric glands also coincided, at the molecular level, with the detection of pepsinogen RNA messengers as it has been shown in winter flounder (Douglas et al., 1999). The importance of a functional stomach in the digestive process of fish larvae is not yet clearly established.

\section{Pancreas}

\section{Anatomic and morphological development}

The pancreas with its endocrine and exocrine parts has two functions (Figure 13). The endocrine pancreas delivering hormones such insulin and glucagon into the bloodstream is vital for the regulation of the carbohydrate metabolism in the body. The exocrine pancreas is the main source of digestive enzymes for the intestinal digestion of the nutrient macromolecules (Hoehne-Reitan and Kjørsvik, 2004). The organogenesis of the pancreas can be divided in three phases: appearance of a primordium at hatching, in the form of a dorsal bud on the digestive tract; differentiation of the exocrine cells (Figure 14) and appearance of the excretory ducts and blood vessels before mouth opening; and growth of the organ during the larval and juvenile period. The quantitative growth after differentiation includes tissue size, an increase in the relative frequency of zymogen granules (Figure 15), an increase in enzyme synthesis and secretion, while no new structural elements develop. Histological techniques, as well as immunohistochemical and molecular procedures employed to detect pancreatic enzymes or their precursors have revealed that the larval exocrine pancreas appears histologically differentiated and functional at hatching or mouth opening (Figure 16). In haddock, Atlantic cod and summer flounder, the pancreas contains acidophilic zymogen granules and exocrine cells are arranged in acini just after hatching, whereas in Dover sole, Senegal sole, California halibut, gilthead seabream, common dentex and common pandora the pancreas achieves its acinar structure and contains zymogen granules at mouth opening. The later development is mainly characterized by quantitative growth, while no new structural elements develop and turning into a diffuse tissue towards the end of the larval stage and during the juvenile period (Beccaria et al., 1991; Hoehne-Reitan and Kjørsvik, 2004). There exist very few studies describing the histological development of the endocrine pancreas. At hatching the endocrine cells are not yet differentiated into the different types seen in juveniles and adults. In both European sea bass and gilthead seabream, the primordial pancreas appears as a posterodorsal thickening of the right side of the foregut in posthatched larvae. This primordial pancreas extends laterally, generating a pancreatic tissue that spreads along blood vessels and the intestinal wall (Figure 17A). In both species by the second day after hatching, the cell mass differentiates into two separate cell populations, exocrine and endocrine cells, and the endocrine forming already a small islet (Figure 17B) (Garcia-Hernández and Agulleiro, 1992; Guyot el al., 1998). There is differential development of the pancreas in sea bass and principal islets develop dorsally and later several small islets appear ventrally. At day 9 in European sea bass larvae, a single islet is found, which will subsequently increase and develop; and at day 60 a big islet, an intermediate and several small islets can be found, these containing the main pancreatic endocrine cells (García-Hernández and Agulleiro, 1992) (Figure 19). During the lecitotrophic stage, pancreatic endocrine cells start to differentiate and become grouped in only one islet of Langerhans. In Atlantic cod, all endocrine cells contain membrane-bound secretory granules with halos, but some have darker cytoplasm than others. Some of the darker cells are irregular in shape, contain many small, dense, often crystalloid granule, and have been considered as alpha cells; whereas some of the lighter cells have an ovoid nucleus with an extracted appearance, contain granules of more irregular shape and density, and could be "large" or "clear" cells. Occasionally needle-shaped granules are seen in cells bordering on capillaries, which could be beta cells, but processes of the other types of cells also appeared to extend to the capillaries. Some of these have granules without a well-developed core and halo, and could be delta cells (Morrison, 1993). 


\section{Biochemical description of development}

\section{Detection of hormones}

At least four cell types: insulin, glucagon, somatostatin, and PP can be revealed using optic (immunohistochemical techniques) and electron microscopy; these cells are generally designed as B, $A, D$ and $F$ cells respectively.

During the early stages of European sea bass development, the primordial cord is composed of cells immunoreactive for both insulin and somatostatin ( 25 and 14 forms, D1 and D2, respectively). At day 9 , glucagon cells were first identified in the periphery of the main islet and at 25 days old larvae, PP immunoreactive cells were detected in the outer region of the islet as well (Table 9) (GarcíaHernández and Agulleiro, 1992). Inside the islet exists a regional distribution, with D1, A and F cells at the periphery, B cells the innermost and D2 cells at intervening locations. In turbot and gilthead seabream, clumps of B cells are the first cell type to appear immediately following hatching, emerging from a single primordial islet at the epithelium of the undifferentiated intestinal tube. Insulin cells persist as this islet enlarges, with new smaller islets also forming (Berwert et al., 1995; Guyot et al., 1998). In Japanese flounder insulin cells are present in pancreas primordium at hatching and form a principle islet at 20 days posthatching (Kurokawa et al., 2000). The onset of feeding in turbot (5-7 days) has been correlated with the appearance of $D$ cells and $A$ cells, with variations in distribution among the differently sized islets. The principal islets exhibited an intermingling of $B$ and $D$ cells while smaller islets displayed D cells at the periphery along with A cells. F cells were the last cells to appear, emerging 12 days posthatching. In Japanese flounder, $F$ cells were not detected in the principle islet, but were found in accessory islets at 30 days posthatching (Kurokawa et al., 2000). Moreover, IGF-I appeared at day 11 in $F, A$, and D cells. This sequenctial appearance: of $B, D, A$ and $F$ cells in the ontogeny of the turbot pancreas follows the phylogenetic order. A biochemical study of sea bream (Guyot et al., 1998) revealed that the highest insulin levels occur at hatching when the pancreas primordium is about to form and when yolk absorption is the primary source of alimentation. The authors suggested that this insulin is most likely of maternal origin and is utilized for organ growth and differentiation. The coordinated development of islet organ, liver and intestine are critical to larva survival. .Adequate insulin production is of paramount importance in order to respond the absortion of exogenous food. Furthermore, the early appearance of insulin underscores its critical role in regulation of fish metabolism.

\section{Detection of enzymes}

In fish larvae, some pancreatic enzymes, namely trypsin and amylase, can be detected before mouth opening showing that enzyme synthesis is not triggered by food ingestion (Zambonino Infante and Cahu, 2001); the activity of these detected enzymes sharply increased at the time of mouth opening (Ribeiro et al., 1999a; Zambonino Infante and Cahu, 2001), moment that also coincided with the first secreted zymogen granules (Beccaria et al., 1991). The ability to secrete pancreatic enzymes has been shown to increase significantly around the third post-hatching week in temperate fish species (earlier in tropical species), suggesting that the mechanisms involved in pancreatic zymogen secretion develop later than those involved in zymogen synthesis (Zambonino Infante and Cahu, 2001) as reported for others vertebrates (Henning, 1987). After this developmental stage, it can be considered that the maturation of the pancreatic secretory function is achieved in temperate marine fish larvae. The presence of all main pancreatic enzymes in fish larvae at the moment of mouth opening has been widely shown for different marine fish species, as in sea bass (Vu, 1983), white bream (Cara et al., 2003), and sole (Ribeiro et al., 1999b). At this particular developmental event, effective synthesis of zymogens by fish larvae pancreas was demonstrated by detecting their corresponding RNA messengers using whole mount in situ hybridization (Srivastava et al., 2002). Marine fish larvae from temperate water exhibited similar pattern in pancreatic enzyme specific activities (activity per gram of protein) assayed in total larvae body, during the first three weeks of life (Zambonino Infante and Cahu, 2001): an increase until a certain date, followed by a sharp decline. The date of the decline depends on the species (Figure 20): around the third week of life in sea bass (Zambonino Infante and Cahu, 1994), and red drum (Buchet at al., 2000), the $10^{\text {th }}$ day in Senegal sole (Martinez et al., 1999; Ribeiro et al., 1999b) and the $5^{\text {th }}$ day in barramundi (Ma et al., 2001). This decline in specific enzyme activity can be mainly explained by the normal increase of tissue proteins in growing larvae, reflecting anatomical and physiological changes in fish larvae, and does not correspond to a lowering in the amount of digestive enzymes. This particular enzymatic profile, showing a succession of increase and decrease with time, characterizes post-natal enzymatic changes in fish larvae as well as other vertebrates including mammals (Henning, 1987). The activity of 
most of assayed pancreatic enzymes, namely trypsin, chymotrypsin, lipase and phospholipase A2, tend to significantly increase with larval development (Ozkizilcik and Chu, 1996; Zambonino Infante and Cahu, 1999). On the contrary, the activity of amylase is higher in young larvae than in older ones, exhibiting a gradual decline during development (Ribeiro et al., 1999b; Buchet et al., 2000; Zambonino Infante and Cahu, 1994). Several authors (Douglas et al., 2000; Ma et al., 2001) demonstrated that this decline in activity resulted from lower amylase mRNA levels in older larvae, revealing a transcriptional control of the expression of this enzyme (Figure 21). Péres et al. (1996) also showed that the decline in amylase activity was irrespective of the dietary carbohydrate concentration, and hypothesized that this decrease in amylase activity during larval development is genetically programmed. This particular change in amylase may suggest a natural predisposition of young larvae to use carbohydrates during the first weeks of life (Krogdahl and Sunby, 1999).

\section{Regulatory factors}

\section{Effect of food deprivation}

Food deprivation induces degeneration of the exocrine pancreas (Ooezeki et al., 1989; Yúfera et al., 1993; Gwak et al., 1999; Crespo et al., 2001). Pancreatic enzymes appear to be particularly sensitive to food deprivation in teleost larvae (Zambonino Infante and Cahu, 2001). Gwak et al. (1999) reported a decline of trypsin and amylase activities in starving Japanese flounder ( $P$. olivaceus) to very low levels, which was associated with a reduction of pancreatic volume and partial necrosis of the exocrine pancreas. In other species, such as California halibut (Gisbert et al., 2004b) or gilthead seabream (Yúfera et al., 1993), while the exocrine pancreas degenerated due to starvation, zymogen granules were still present in starved larvae.

\section{Effect of carbohydrates}

Young larvae exhibited higher amylase activities than older ones suggesting a predisposition to use glucides during the first weeks of life and some authors suggested to formulate diets incorporating significant levels of starch (Buddington, 1985; Zambonino Infante and Cahu, 2001). Péres et al. (1996) showed in European sea bass larvae that the normal decline in amylase was slower when larvae were fed diets containing $25 \%$ glucides compared to $5 \%$ glucides. This data revealed a swift adaptation of the enzyme to its substrate level, and this process was extensively reported for amylase in mammals and fish (Kawai and Ikeda, 1973; Sheele, 1993). Similarly, Ma et al. (2005) suggested that the high level in glycogen in Artemia limited the decrease in amylase activity in yellow croaker (Pseudociaena crocea). Nevertheless, diets containing high glucide levels induced poor larval growth and survival, concurrently with a delay in the normal decline in amylase (Péres et al., 1996). This result does not support the hypothesis of a special nutritional need of marine fish larvae for carbohydrates.

\section{Effect of proteins}

It has been shown that a good development of carnivorous fish larvae can be obtained with 50$60 \%$ dietary proteins (Péres et al., 1996). In addition, the dietary incorporation of moderate levels of protein hydrolysates, substituting native proteins, improves the larvae development (Carvalho et al., 1997; Kolkovski and Tandler, 2000). Fish larvae exhibited a great digestive capacity for protein since the earliest stages of their development (Srivastava et al., 2002; Cara et al., 2003). The main enzyme involved in protein digestion, trypsin, is modulated by dietary protein content (Figure 22). Recent data (Cahu et al., 2004) has evidenced a post-transcriptional regulation of trypsin expression in response to dietary native protein content in 25 days-old European sea bass larvae, when this same adaptative response was regulated at the transcriptional level at day 42. Péres et al. (1998) also reported a modulation of trypsin transcription by dietary protein nature in 40 days-old sea bass larvae. The switch from a post-transcriptional to a transcriptional control of trypsin expression probably reflects a maturational process; this was supported by the fact that trypsin regulation is mainly under transcriptional control in vertebrates (Sheele, 1993).

\section{Effect of lipids}

Lipid fraction of the fish larvae diet is mainly constituted by triglycerides and phospholipids, incorporated at different levels. Activities and mRNA of enzymes involved in lipid digestion can be detected in the first-feeding marine fish larvae and the expression of these enzymes increased with development (Izquierdo et al., 2000; Srivastava et al., 2002). The expression of lipolytic enzymes of pancreas, lipase and phospholipase A2, are modulated, mainly at the transcriptional level, by the dietary content of their respective substrate triglycerides and phospholipids (Zambonino Infante and Cahu, 2001). On one hand, it appeared in sea bass larvae that the modulation of lipase expression was rather undefined (Figure 23A) being more regulated by the source of triglycerides (chain length 
and degree of saturation) than by the dietary triglyceride concentration itself (Cahu et al., 2003; Morais et al., 2004). On the other hand, the regulation of phospholipase A2 expression was gradual (Figure 23B) and exhibited a major modulation range than lipase (Cahu et al., 2003); morevover, larvae development was greatly improved when diet incorporated at least $10 \%$ phospholipids. Taken together, these data strongly suggest that marine fish larvae utilize more efficiently phospholipids than triglycerides, as reported by Shield et al. (1999) in halibut.

\section{Influence of diets on pancreatic secretion}

The pancreatic secretory process matures during the first three-four weeks of life post-hatching in temperate marine fish larvae. This maturational process can be disrupted when larvae were fed diets that do not meet their specific needs (Cahu and Zambonino Infante, 1994): the earlier the feeding with such inadequate diets, the lower the pancreatic secretion level. At the opposite, some dietary components, i.e. free amino acids (Zambonino Infante and Cahu, 1994) or some non-biodegradable particles (Pedersen and Andersen, 1992) can enhanced pancreatic secretion revealing the coexistence of chemical and neural mechanisms controlling secretion in larvae.

\section{Liver}

\section{Anatomic and morphological development}

The liver is of significant importance for the nutrition and homeostasis in fish. This organ is central for nutrient metabolism, conversion, and transfer to peripherical tissues with a predominant role in intermediary metabolism, and important functions in lipid storage, but also for the production of bile for intestinal lipid breakdown, as well as for the breakdown and excretion of metabolic products, and detoxification processes (Rust, 2002; Hoehne-Reitan and Kjørsvik, 2004).

The morphological development and the onset of bile synthesis and secretion are key factors to determine functionality in the larval liver. The fish liver develops from a ventral budding of the gut, in close connection to the yolk-syncytium (Hoehne-Reitan and Kjørsvik, 2004). In cold-water species such as haddock (Hamlin et al., 2000) and Atlantic cod (Morrison, 1993), the liver is differentiated at hatching, and the hepatocytes are arranged in a chord-like pattern between the sinusoids. The bile duct connecting the liver and intestine is already differentiated and is lined by a single layer of epithelial cells. Whereas in temperate-water species, such as gilthead seabream (Sarasquete et al., 1995), common pandora (Micale et al., 2005), common dentex (Santamaría et al., 2004) and California halibut (Gisbert et al., 2004), the liver is absent when the larva emerges from the egg envelope, starting to differentiate between 1 and 2 days after hatching (Figures 14). In gilthead seabream, the hepatocytes still have the ultrastructural characteristics of the cells forming the wall of the digestive tract at hatching and start to differentiate during the establishment of the intrahepatic bile and blood system. In European seabass and gilthead seabream, the primordial liver remains connected to the gut wall by a cell cord, which becomes tubular and successively gives rise to the choleduc duct, cyst duct and the gallbladder (Guyot el al., 1995; Diaz and Connes, 1997) (Figure 18). During the lecitotrophic stage, spherical hepatocytes with centrally located basophilic nuclei and slight eosinophilic homogeneous cytoplasm differentiate, becoming polyhedral. After the transition to exogenous feeding, hepatocytes increase in size and number, and are tightly packed between sinusoids, often around a central vein (Figure 24). The macroscopical organization of the liver in two or more distinct lobes, depending on the species, is achieved at the end of larval metamorphosis and during early juvenile stages.

One criterion of a functional liver is the ability to synthesize, store and mobilize carbohydrates (Figure 8) and lipids (Figure 24). The contribution of the liver in the storage and mobilization of carbohydrates and lipids in early life stages has only been studied in detail in a few species. During the lecitotrophic stage, the liver of gilthead seabream larvae mainly accumulates glycogen, while during the transition from endogenous to exogenous feeding this glycogen is reabsorbed, being reconstituted after the completion of yolk sac reserves. In other species such as Atlantic cod and Atlantic halibut, glycogen deposition in the liver is not apparent during the yolk-sac stage, although a significant increase is observed after yolk sac absorption. Differences between species in hepatic glycogen content during the endogenous feeding stage might possibly be related to the yolk lipid content and larval energy metabolism at this stage (Hoehne-Reitan, and Kjørsvik, 2004.). The storage of reserves in hepatocytes progressively increases the vacuolisation level of their cytoplasm after the onset of exogenous feeding. Glycogen (eosinophilic PAS-positive granules) and lipids (colourless, PAS-negative and Sudan black-positive vacuoles) are stored in the hepatocytes (Figures 8 and 24) 
while proteins are more evident in the hepatic vascular system (Figure 15). The position of the nucleus in the hepatocytes' cytoplasm depends on the degree of accumulation of nutrient reserves. Large central nuclei are observed in livers containing few lipid inclusions, while peripheral nuclei are detected in livers of larvae showing high levels of lipid deposition (Deplano et al., 1991; Gisbert et al., 2005).

\section{Biochemical description of development}

Most of the studies have focused on enzymes involved in the ornithine-urea cycle. Some authors have demonstrated that the ornithine-urea cycle is expressed during early development in some freshwater (Wright et al., 1995; Terjesen et al., 2001) and marine fish species (Chadwick and Wright, 1999; Terjesen et al., 2002) as a mechanism for eliminating ammonia produced from the catabolism of yolk protein. In particular, the ornithine transcarbamylase and the carbamoyl phosphate synthetase were expressed at higher levels in embryos and larvae than in adult fish.

\section{Regulatory factors}

Liver is often used as indicator organs of the nutritional and physiological status in fish. This organ is the central metabolic organ of the body with a predominant role in intermediary metabolism, and important functions in lipid storage, and digestive and detoxification processes. The histomorphological organization of the liver accurately reflects any physiological umbalance due to starvation or nutritional problems. Observed dietary effects on the liver may be seen as intra- or extracellular structural change, of which resorption of glycogen and lipids and changes in mithochondria appearance are the earliest signs of change (Hoehne-Reitan and Kjørsvik, 2004).

\section{Effect of Food deprivation}

The liver is an adequated target organ to nutritional disorders. During ontogeny of fish species, larvae are especially sensitive to non-optimal feeding conditions or nutritional stress, because most tissue and organs are under progressive developing. Starvation results in a linear change of some parameters, i.e. cell size, hepatic glycogen and lipid, whereas other parameters such as condition factor, liver-somatic index, liver protein content, RNA-DNA-ratio, the activity of gluconeogenic and glycogenolytic enzymes revealed a non-linear reaction under starvation. This fact can suggest the existence of two phases in the metabolic adaptation of starved fish larvae: a first phase of metabolic disturbance, followed by a second phase, the establishment of a new homeostasis for maintaining liver metabolic integrity (Moon and Johnston, 1980). Hepatic energy stores respond sensitively to nutritional changes or deficient diets (Segner et al., 1994).

Under food deprivation conditions, liver glycogen and lipids are the first energy sources mobilized. The mobilization of these nutrients under the conditions of continued fasting results in the reduction of energy available to larvae (Green and McCormick, 1999). Thus, once yolk sac and oil globule reserves are exhausted, the histological organization of different regions of the digestive tract and accessory organs progressively deteriorates as a consequence of food deprivation. Histopathological changes in food-deprived larvae are similar amongst different species, and include changes in the liver organization (swollen and deformed mithochondria, dilated sinusoids, large intercellular spaces, vascularization, increase in lysosomes, cytoplasmic necrosis, and hypertrophy of the bile canaliculi and the gall bladder) and a decrease in glycogen and lipids deposits stored in hepatocytes (Margulies, 1993; Yúfera et al., 1993, 1996; Diaz et al., 1998; Green and McCormick, 1999; Crespo et al., 2001; Gisbert et al., 2004b).

\section{Effect of lipids}

The hepatic energy stores respond sensitively and rapidly to nutritional changes in fish larvae, and this organ is thus a good biomarker for nutritional effects of different dietary composition and feeding regimes (Hoehne-Reitan and Kjørsvik, 2004). In well-fed larvae, glycogen and lipids tend to accumulate in varying degrees. The liver volume generally increases, and the rough reticulum endoplasmatic and Golgi apparatus increase as the larvae develop, whereas in larvae fed suboptimal diets; the above-mentioned cellular organelles are poorly developed (Segner et al., 1993). Problems associated with dietary lipids seem to be the most serious in adult and fish larvae nutrition (HoehneReitan and Kjørsvik, 2004), and especially related to a deficiency of the highly unsaturated essential fatty acids (HUFA), in particular of the n- 3 and n- 6 series or an imbalance between them (Fontagné et al., 1998; Izquierdo et al., 2000; Sargent et al., 1999, 2002; Gisbert et al., 2005). The hepatic vacuolisation (neutral lipids) observed in fish larvae fed with Artemia naupli has been indicative of adequate nutrient absorption (Segner et al., 1994; Sarasquete al., 1995; Gisbert et al., 2004a). Dietary 
fatty acid deficiency is linked to a swollen, pale liver with a severe lipid infiltration of the hepatocytes. A deficiency of n-3 HUFA results in increased lipid content in the liver of gilthead seabream, while African catfish larvae (Clarias gariepinus) fed live prey with low n-3 HUFA levels exhibited a higher glycogen content and less lipids in the liver than those fed high n-3 HUFA levels (Hoehne-Reitan and Kjørsvik, 2004). The form of supply of HUFA (phospholipids vs. neutral lipids) has a direct effect on fat storage in the liver (Gisbert et al., 2005). Thus, European sea bass larvae fed compound diets with high levels of n-3 HUFA in the neutral lipid fraction showed higher levels of lipid accumulation in the liver than those fed similar or even higher levels of n-3 HUFA contained in the diet as phospholipids. Increased basophilia observed in the cytoplasm of the hepatocytes of larvae fed with deficient inert diets have been related with disorders of glycogen and proteins synthesis and/or utilization (Segner et al., 1994; Sarasquete and Gutiérrez, 2005). Other authors hypothesised that one cause of failure for some compound diets during early feeding and weaning of altricial marine fish larvae might thus be due to a diet-induced inability to synthetize biliary lipids (see review in Hoehne-Reitan and Kjørsvik, 2004).

\section{Intestine}

\section{Anatomic and morphological development}

The intestine is the longest portion of the digestive tract. Newly hatched larvae have a rudimentary intestine lined by a simple columnar epithelium with median to basal nuclei and a striated border of microvilli projecting from the apical surface of cells (Figure 18). During the yolk-sac phase, the posterior region of the intestine bends and the intestinal valve or ileo-rectal valve (Figure 25) appears as a constriction of the intestinal mucosa dividing the intestine in two regions, the prevalvular (anterior) and postvalvular (posterior) intestine (Table 8). At this stage, the intestinal mucosa was mostly rectilinear with several short folds. In most species, no histological differences are observed between the pre- and postvalvular intestine: both regions are lined by a simple columnar epithelium with basal nuclei, slightly basophilic cytoplasm and prominent eosinophilic microvilli. The intestinal epithelium is surrounded by a thin muscular layer composed of two layers: one circular internal and another longitudinal external separated by a very thin connective tissue. The postvalvular intestine terminates in a short rectal zone lined by cuboidal epithelium and deprived of folds and goblet cells. At this level, the urinary bladder emerges outside the digestive tract posterior to the anus.

During larval development, the intestine coils and forms a loop to accommodate its increasing size in the visceral cavity (Figure 4), intestinal folding increase and goblet cells differentiate in the epithelium (Figure 26). Three distinct regions can be distinguished along the intestine according to their histological organisation. The antero-median segment (prevalvular intestine) receives the pancreatic and biliary secretions and is histologically characterized by a columnar epithelium with prominent microvilli with a high number of goblet cells, very abundant close to the pyloric sphincter (Figure 27). This region of the intestine is the main site of the digestive tract for lipid absorption (Diaz et al., 1997; Olsen et al., 2000), while proteins are absorbed in the posterior intestine (Deplano et al., 1991) (Figures 28 and 29). However, other studies have reported that lipid digestion and absorption continues in the posterior and rectal regions of the intestine, particularly in carnivorous fish with short digestive tracts (Smith, 1989), such as European sea bass larvae (García-Hernández et al., 2001; Gisbert et al., 2005). The postvalvular intestine is histologically similar to the anterior-median region with the difference in the number and size of mucosal folds (Figure 30), which are longer, deeper and more numerous in the prevalvular intestine (Figure 31). The intestine terminates in a short rectal zone (Figure 27), which depending on the species can be either lined by a simple or columnar epithelium with few goblet cells like in yellowtail flounder and Dover sole or by a cuboidal epithelium like in California halibut, white seabream, European sea bass or spotted sand bass.

Goblet cell differentiation in the intestinal mucosa follows two different patterns according to the larval stage of development during which they differentiate (Table 8). Thus, in some species, such as Dover sole, yellowtail flounder and spotted sand bass, goblet cells appear in the intestinal mucosa coinciding with the onset of exogenous feeding or just before first feeding, while in gilthead seabream, California halibut, Senegal sole, common pandora, common dentex and haddock, they differentiate at latter stages of development (Table 3). Intestinal goblet cells contain a mixture of neutral (PASpositive) and acid glycoproteins (Alcian blue $\mathrm{pH}$ 0.5, 1, 2.5-positive) and the histochemical pattern of their content does not change through larval and juvenile periods to adult ages (Domeneghini et al., 1998). Mucosubstances produced by rectal and distal postvalvular intestine goblet cells may serve to lubricate the feces, while in other regions of the intestine they protect the digestive mucosa and 
facilitate the absorption of nutrients. The presence of neutral glycoconjugates and alkaline phosphatase activity in the brush border of the intestinal epithelium has been positively correlated with absorption and transport of macromolecules through membranes (Stroband et al., 1979). Considering that the distal part of the intestine of most species is capable of ingesting and digesting proteins via pinocytosis, several authors have assumed that the mucosubstances secreted by goblet cells, especially the sulphated ones, may regulate the transfer of protein or protein fragments (Domeneghini et al., 1998).

During larval development, entero-endocrine cells, so-called rodlet cells, develop between the enterocytes throughout the intestinal epithelium in several species such as Atlantic cod (Morrison, 1993), turbot (Padrós, pers. com.), gilthead seabream (Calzada et al., 1998) and common dentex (Santamaría et al., 2004) larvae. Although the endogenous origin of these cells is well established (Kramer and Potter, 2003), their function still remains an enigma, but their possible role in non-specific defence mechanisms has been pointed by several authors (Leino, 1996; Manera et al., 2001; Santamaría et al., 2004).

The development of pyloric caeca represents the last major morphological change of the intestinal development in spotted sand bass, haddock, summer flounder and yellowtail flounder (Figure 32). The differentiation of pyloric caeca in the intestine and gastric glands in the stomach, which results in a digestive system similar to the adult, determines the transformation from the larval to the juvenile stage (Bisbal and Bengtson, 1995). Pyloric caeca are involved in nutrient digestion and absorption (lipid), primarily by an increase of surface areas without increasing the length or thickness of the intestine itself (Buddington and Diamond, 1987). These structures facilitate digestion by transport of absorbable nutrients to the bloodstream before passage of the food bolus to the intestine for further breakdown and absorption. They also neutralize the acid bolus entering the intestine from the stomach, which is supported by the absence of these structures in stomachless fish (Rust, 2002). Pyloric caecal formation starts by the end of the larval period when an epithelial ridge separates the stomach in differentiation from the prevalvular intestine. The ridge is visible as a series of small pocket-like evaginations of the intestinal wall, which later develops into the finger-like projections typical of pyloric caeca. The mucosa of the pyloric caeca does not show any difference from its intestinal counterpart, and is lined by a columnar epithelium are covered with a dense layer of microvilli. The goblet cells of this region contain a mixture of neutral and acid glycoproteins (PAS and Alcian blue-positive) and are more numerous than in other regions of the intestine, but less numerous than in the oesophagus.

Regarding to absorption processes in fish larvae, fat droplets in the intestinal epithelium have been reported either in larvae and adult teleost fish. Ingested lipids are hydrolysed, absorbed and after being resynthesised they are stored as lipid droplets in enterocytes (Iwai, 1969; Loewe and Eckmann, 1988). In fish larvae, lipid droplets are not considered as part of the endoplasmatic reticulum of Golgi apparatus of enterocytes and in many cases they do not appear to be enclosed by any membrane. This has led to the suggestion that intestinal lipid inclusions are a temporary storage form of reesterified fatty acids in cases when the rate of lipid absorption exceeds the rate of lipoprotein synthesis (Sheridan, 1988), or because an inability to metabolise lipids (Kjørsvik et al., 1991). Deplano et al. (1991) suggested that the excessive abundance of lipid droplets of varying size in the intestinal absorptive cells/enterocytes could be the result of a default in the lipoprotein synthesis mechanism. The rapid development of the intestinal enterocytes during larval growth is combinated with increasingly effective lipoprotein synthesis, accompanied by a considerable decrease in number of large lipid vacuoles in the enterocytes, as well as an important increase in the number of small lipid particles in the intercellular spaces (Deplano et al., 1991; Sarasquete et al., 1995). The final portion of the intestine is actively involved in the absorption of digestive products during the larval stage. Acidophilic supranuclear inclusions (so-called supranuclear bodies) have been usually observed in the posterior intestine of larvae (Govoni et al., 1986; Kjørsvik et al., 1991; Sarasquete et al., 1993, 1995; Ribeiro et al., 1999; Hamlin et al., 2000) (Figures 28 and 29). These inclusions reflect the absorption of protein macromolecules by pinocytosis as an alternative pathway until the stomach develops a high proteolitic capacity. During the transition from endogenous to exogenous feeding, the postvalvular intestine has a basic nutritional role assuring a large protein of protein absorption in macromolecular form, but is also involved in the assimilation of simple molecules. The characteristics of enterocytes located in this region of the intestine are similar to those of the adult, though at a very limited level of activity. Electron microscopy studies revealed the presence of a scarcely developed apical tubulovesicular system with medium or high electron-dense content and several vacuoles in enterocytes, which indicates a reduced capacity for absorption by pinocytosis. In parallel, histochemical methods show that the acid phosphatase activity characteristic of lysosomal systems is 
low, suggesting that the capacity for intracellular digestion is also low. After the transition to exogenous feeding, enterocytes maturation proceeds and their tubulovesicular system greatly develops increasing their capacity for protein absorption, which appears to be much greater than in adults (Deplano et al., 1991; García-Hernández et al., 2001). In most of studied species, supranuclear bodies are observed throughout the larval period, although their number and size decreased as the stomach differentiated and extracellular digestion took place. The reduction of supranuclear bodies in the postvalvular intestine after the acquisition of the gastric function may result from a change in the protein digestion mechanisms, as the secretion of hydrochloric acid and enzymes produced in gastric glands may reduce pinocytotic activity and intracellular digestion by cytosolic enzymes, leading to extracellular digestion processes (Cahu and Zambonino-Infante, 2001).

\section{Biochemical description of development}

\section{Detection of hormones}

Numerous regulatory peptides have been identified in fish gastro-entero-endocrine cells (GE), including those found in the pancreas and certain GE-specific molecules. Nevertheless, very little is known of their ontogenic development, despite important studies published on European eel (Anguilla anguilla) (L'Hermite et al., 1985), European sea bass (García-Hernández et al., 1994), turbot (Reinecke et al., 1997) and Japanese flounder (Kurokawa et al., 2000).

In European sea bass, serotonin was first identified in the rectum and stomach of 2-5 day-old larvae, as well as in 8-10 day-old turbot (García-Hernández et al., 1994; Reinecke et al., 1997).

Glucagon and related peptides were identified in the intestinal epithelium and stomach of 8-11 days turbot larvae and in 25 days sea bass larvae. Their immunological properties suggest that the signal detected in these studies corresponds to enteroglucagon

Only slight labeling of small intestine for glucagon appears in leptocephali eel just prior to metamorphosis. Thereafter, glass eel exhibit abundant glucagon cells in duodenal bulbous extensions and minimal staining in the small intestine and rectum.

PP/NPY (polypeptide pancreatic/neuropeptide $Y$ ) cells are detected in European sea bass initially in the intestine (9-15 days) and subsequently in the stomach (55-60 days). A similar chronology was observed in turbot, 8-10 days for intestine and 11-12 days for stomach. In Japanese flounder PY (peptide $\mathrm{Y}$ ) cells appeared in intestinal epithelia at 3 days posthatching when the larvae began to feed, suggesting that these cells play a role in the regulation of pancreatic enzyme secretion (Kurokawa and Suzuki, 2002).

CCK(cholecystokinin)/Gastrin was identified in the intestine of sea bass larvae at 9-15 days; however using human gastrin-17 antiserum, the signal was also detected in the stomach, while CCK proved much more abundant in the instestine. Similar results were observed in 11-17 day old turbot larvae, in which CCK/Gastrin was more prominent in the upper intestine than in the stomach.

In Japanese flounder, CCK is expressed in intestinal epithelia 1 day prior to the first feeding, suggesting that this hormone is already stimulating secretion of pancreatic enzymes at this time (Kurokawa et al., 2000). In contrast, no CCK cells were found at first feeding of Atlantic halibut larvae (33 days after hatching); 12 days later, however, a few CCK cells were scattered in the epithelium of the anterior midgut; at day 52 these cells become particularly prevalent in the most an terior region, adjacent to the pyloric caeca (Kamisaka et al., 2001). The mechanisms regulating of pancreatic enzymes, bile release etc. in halibut during the first 12 days after feeding, remain unknown.

Generally speaking, somatostatin 14 appears mostly in the stomach of teleost, and in sea bass both this molecule and somatostatin 25 were found in the gastric epithelium prior to the differentiation of gastric glands (25-46 days). Similar results were obtained in developing turbot and eel (Reinecke et al., 1997, L'Hermite et al., 1985).

It is generally accepted that during phylogeny, cells secreting insulin leave the gut mucosa moving into pancreatic islets. Although insulin immunoreactivity was detected in European sea bass stomach at 25 days, the authors contented that this was most likely a molecule different from pancreatic insulin. Reinecke et al., (1997) hypthesized that such immunoreactivity represents a cross reaction with IGF-I, which appears in turbot GE around day 8 and becomes a rather conspicuous component of the stomach and intestine from days 17 to 41 post-hatching. This is consistent with the important role this growth factor plays in fish development (Méndez et al., 2001; Smith et al., 2005). 
Other regulative molecules, in either cells or nervous fibers are also present in fish larvae GEP. Nerve fibers containing VIP immunoreativity are the first (day 5) located in turbot, appearing throughout the gastrointestinal tract, with highest density occurring in stomach anlage. Subsequently, VIP cells appeared to be restricted to the intestine. It has been suggested that VIP can exert multiple effects (gastric secretion, motility, vasodilatation) and that play a central role in the gastrointestinal physiology in early larvae (Reinecke et al., 1997). There is less information available on neurotensin, substance $\mathrm{P}$, met-enkephalin, chromogranin, and pancreastatin in marine fish larvae.

In summary, different stages for the detection of regulatory peptides in digestive tract can be distinguished 1) At the onset of external feeding only transient insulin cells, serotonin cells and VIP fibers are present; 2) In the early phases of exogenous feeding, a differentiation of the enteroendrocine system occurs and many hormones can be found: PP and related peptides, IGF-I, somatostatin, glucagon, etc.; 3) Prior to the final differentiation of the stomach and gut CCK/Gastrin cells appear.

\section{Detection of enzymes}

The development of a functional intestine implies different maturational and morphological events that are very well preserved among vertebrates (Henning et al., 1994). From an enzymatic point of view, the appearance of a functional microvillus membrane in enterocytes constitutes a crucial step during larval development of fish for the acquisition of an adult mode of digestion (Zambonino Infante et al., 1997). This specific post-natal change occurs between the $3^{\text {rd }}$ and the $4^{\text {th }}$ week post-hatching in temperate species. This is demonstrated very nicely by considering protein digestion. During the first three weeks of life, the terminal stages of protein digestion in intestinal compartment occurs inside the enterocytes, where very high activities of cytosolic peptidases (as Leucine-alanine peptidase) can be detected. A progressive decline in cytosolic enzyme activities was noted until the third-fourth week post-hatching when the activities of the microvillus membrane enzymes rose in many fish larvae species (Moyano et al., 1996; Cahu and Zambonino Infante, 1994; Ribeiro et al., 1999b). The temporal coincidence between the rise of brush border enzyme activities and the decline of cytosolic enzyme activities reveals an ontogenic process and characterizes the normal maturation of the enterocytes in developing fish larvae (Figure 33). This process has been extensively described in mammals (Himukai and al., 1980; Henning, 1987) and fish (Zambonino Infante and Cahu, 2001).

\section{Regulatory factors}

\section{Effect of food deprivation}

Like the liver, the histological organization of the intestine is particularly altered by food deprivation and starving, in particular with the reduction in the height of enterocytes of the intestinal mucosa (Ooezeki et al., 1989; Bisbal and Bengtson, 1995; Theilacker and Porter, 1995; Gwak et al., 1999; Gisbert et al., 2004b). Indeed, proteolysis of the intestinal mucosa is a common response to starvation, thus enterocyte degeneration implies a reduction of the nutrient absorption surface area, compromising the digestive capabilities of re-feeding larvae and directly affecting their growth and survival. For these reasons, the criterion of the enterocyte height has been widely used as a valuable indicator of sub-optimal feeding or starvation in several fish species (Theilacker and Watanabe, 1989; Theilacker and Porter, 1995; Bisbal and Bengtson, 1995; Theilacker et al., 1996; Green and McCormick, 1999; Gisbert et al., 2004b).

\section{Effect of proteins}

During young larval stages, the dietary proteins are mainly hydrolyzed by pancreatic enzymes, releasing oligopeptides in the intestinal lumen; these oligopeptides are absorbed through the immature microvilli of enterocytes and are finally hydrolyzed in free amino acids, di or tripeptides by peptides hydrolases located in the cytoplasm of enterocytes. The development of a functional microvillus membrane led to the decline of the cytosolic digestion (Zambonino Infante and Cahu, 2001). This decline can be modulated by the nature and molecular form of the dietary protein supply: diets containing only native protein or high protein hydrolysate levels (Zambonino et al., 1997) may induce a delay in the decrease in cytosolic activities, and consequently in the increase (or onset) in brush border membrane enzyme activities. This process characterizes the normal maturation of intestine. Diets containing a moderate amount of protein hydrolysate (20\% of the total protein supply) facilitate this maturational process which seem to positively affect larvae survival (Zambonino Infante and Cahu, 1999). 


\section{Effect of lipids}

The variety of lipid inclusions observed in the enterocytes of young larvae can be related to their diet (Diaz et al., 1997). It is known that the size of lipoprotein particles in fish increases with the fat content of feed and the degree of unsaturation of the lipids ingested. Accumulation may result from natural, pathological or experimental disturbance or inadequacy in chylomicron synthesis and their release from enterocytes. Natural inadequacy may be related to the immaturity of the enterocytes, as has been suggested for mammals (Snipes, 1977). Thus, the formation of large lipoproteins and lipid droplets is closely related to the excess of fats in immature enterocytes caused by the high fatty acid contents of preys and diets. In some cases, large accumulation of lipids in intestinal enterocytes (intestinal steatosis) may cause some pathological damage, since large lipid inclusions produce epithelial abrasion, cellular necrosis and/or inflammatory reactions along the intestinal mucosa (Deplano et al., 1989). However, when no evidence of a pathological origin of the steatosis, intestinal fat droplets can be interpreted as a temporary storage form of re-esterfied fatty acids that accumulated when fatty acid uptake exceeds exporting capacities of enterocytes (Fontagné et al., 1998). Differences in lipid absorption and accumulation in different regions of the intestinal mucosa are also influenced by dietary lipid classes, their levels and $n-6 / n-3$ ratio, as it has been recently reported in European sea bass larvae (Gisbert et al., 2005). Larvae fed high levels of neutral lipids (11\%) showed important intracellular and intercellular accumulation of lipid in the anterior intestine, while the anterior intestinal mucosa of fish fed low and moderate levels of phospholipids (13-11\%) and neutral lipids (3$6 \%$ ) had a normal appearance and organization (Gisbert et al., 2005). Similarly, lipid deposition in the posterior intestine depended on the dietary lipid class, since larvae fed different levels of phospholipids showed important signs of steatosis whereas fish fed triglycerides had a lower lipid accumulation in this region. This result probably revealed a specialization of the posterior intestine in the absorption and transport of phospholipids.

From a functional and maturational point of view, 12\% dietary phospholipid content enhances enterocyte maturation (Cahu et al., 2003) and particularly the settlement of an efficient brush border membrane digestion; this positive effect is associated to a very significant improvement in survival and growth of European sea bass larvae.

\section{Effect of others dietary components}

Generally, diets fitting with larvae digestive features facilitate the maturation of the maturational process of the intestine. Nutrients acting on cell differentiation, like polyamines, also influence intestinal maturation (Péres et al., 1997). Tovar-Ramirez et al. (2004) have evidenced a positive effect on gut maturation of dietary live yeast, this effect being attributed to the polyamines secreted by live yeast in the gut lumen. The role of these polyamines have been extensively studied in newborn mammals. Polyamines are ubiquitous molecules involved in several biological processes (Tabor and Tabor, 1984), replication/differentiation of cells and synthesis of nucleic acid and proteins (Bardócz, 1993), facilitating in particular the differentiation and maturation of enterocytes.

\section{Conclusion}

This article attempted to provide a broad review of the ontogeny of the gastrointestinal tract in marine fish larvae, with an emphasis on the knowledge generated in the last 5 years when possible. Nevertheless, this review cannot be considered comprehensive with respect to all organs and functions of the gastrointestinal tract. Several important topics have been slightly tackled or omitted such as gut hormones, ontogeny of the intestinal transporters and binding-proteins, ontogeny of oxidant/antioxidant enzymes, ontogeny of the intestinal immune system....mainly due to a lack of informations for fish models.

Some of these topics warrant future attention; the present tendancy in fish aquaculture for incorporating high levels of lipids in diets will likely need knowledge on the development of antioxydant and transport capacities of fish; in the same way, the recent interest for probiotics in larvae and fish diets will probably generate future research on the intestinal immune system (Gatesoupe, 1999).

Time is ripe for the application of the techniques of molecular biology in the field of fish larvae development, particularly genomics and proteomics, to study the complexicity and overlap of regulatory mechanisms involved in developmental processes and find pertinent players to describe these mechanisms. With respect to the identification of regulatory genes controlling the maturation of 
the gastrointestinal tract, fish larvae constitute an exciting model, that has generated sufficient tools and manipulation protocols so as to attract top-quality investigators in the next decade.

\section{References}

Arellano, J., V. Storch, and C. Sarasquete. 2001. Histological and histochemical observations in the stomach of the Senegal sole, Solea senegalensis. Histol. Histopathol. 16: 511-521

Baglole, C.J., H.M. Murray, G.P. Goff, and G.M. Weight. 1997. Ontogeny of the digestive tract during larval development of yellowtail flounder: a light microscopic and mucous histochemical study. J. Fish Biol. 51: 120-134.

Bancroft, J.D., and A. Stevens. 1990. Theory and Practice of Histological Techniques. Churchil Livingstone, New York.

Bardócz, S., G. Grant, D.S. Brown, and R.A. Pusztai. 1993. Polyamines in food-implications for growth and health. J. Nutr. Biochem. 4: 66-71.

Barka, T., and P.J. Anderson. 1967. Histoquímica. 1st edition. Atika, Madrid.

Beccaria, C., J.P. Diaz, R. Connes, and B. Chatain. 1991. Organogenesis of the exocrine pancreas in the sea bass, Dicentrarchus labrax L., reared extensively and intensively. Aquaculture 99: 339-354.

Berwert, L., H. Segner and M. Reinecke. 1995. Ontogeny of IGF-I and the classical islet hormones in turbot, Scophthalmus maximus. Peptides, 16: 113-122.

Bessey, O.A., Lowry, O.H., Brock, M.J. 1946. Rapid coloric method for determination of alcaline phosphatase in five cubic millimeters of serum. J. Biol. Chem. 164: 321-329.

Bisbal, G.A., D.S. Bengtson. 1995. Development of the digestive tract in larval summer flounder. J. Fish Biol. 47: 277-291

Boulhic, M., and J. Gabaudan 1992. Histological study of the organogenesis of the digestive system and swim bladder of the Dover sole, Solea solea (Linnaeus, 1758), Aquaculture 102: 373-396

Buddington, R. 1985. Digestive secretions of lake sturgeon, Acipenser fulvencens, during early development. J. Fish Biol. 26: 715-723.

Buddington, R.K., J.W. Chen, and J. Diamond. 1987. Genetic and phenotypic adaptation of intestinal nutrient transport to diet in fish. J. Physiol. 393: 261-281

Buchet, V., J.L. Zambonino Infante, and C.L. Cahu. 2000. Effect of lipid level in a compound diet on the development of red drum (Sciaenops ocellatus) larvae. Aquaculture 184: 339-347.

Cahu, C., and J.L. Zambonino Infante. 1994. Early weaning of sea bass (Dicentrarchus labrax) larvae with a compound diet: effect on digestive enzymes. Comp. Biochem. Physiol. 109A: 213-222.

Cahu, C.L., J.L. Zambonino Infante, and V. Barbosa. 2003. Effect of dietary phospholipid level and phospholipid:neutral lipid value on the development of sea bass (Dicentrarchus labrax) larvae fed a compound diet. Br. J. Nutr. 90: 21-28.

Cahu, C., I. Rønnestad, V. Grangier, and J.L. Zambonino Infante. 2004. Expression and activities of pancreatic enzymes in developing sea bass larvae (Dicentrarchus labrax) in relation to intact and hydrolyzed dietary protein; involvement of cholecystokinin. Aquaculture 238: 295-308.

Calzada, A., A. Medina, and M.L. González de Canales. 1998. Fine structure of the intestine development in cultured seabream larvae. J. Fish Biol. 53: 340-365

Cara, J.B., F.J. Moyano, S. Cardenas, C. Fernandez-Diaz, and M. Yufera. 2003. Assessment of digestive enzyme activities during larval development of white bream. J. Fish Biol. 63: 48-58.

Carvalho, A.P., A.M. Escaffre, A.. Oliva-Teles, and P. Bergot. 1997. First feeding of common carp larvae on diets with high levels of protein hydrolysates. Aquat. Int. 5: 361-367.

Chadwick, T.D., and P.A.. Wright. 1999. Nitrogen excretion and expression of urea cylce enzymes in the Atlantic cod (Gadus morhua L.): a comparison of early life stages with adults. J. Exp. Biol. 202: 2653-2662. 
Cousin, C.B., and F. Baudin-Laurencin. 1985. Morphogénèse de l'appareil digestif de la vessie gazeuse du turbot, Scophthalmus maximus L. Aquaculture 47: 305-319.

Crespo, S., M. Marín de Mateo, C.A. Santamaría, R. Sala, A. Grau, and E. Pastor. 2001. Histopathological observations during larval rearing of common dentex Dentex dentex L. (Sparidae). Aquaculture 192: 121-132

Culling C.F.A., R.T. Allison, and W.T. Barr. 1985. Cellular Pathology Techniques, 4th edition, Butterworths, London.

Darias, M.J. 2005. Balance energético y ontogenia del aparato digestivo durante el desarrollo larvario del pargo, Pagrus pagrus, y del sargo, Diplodus sargus, en cultivo. Doctoral Thesis, Universidad de Cádiz, Spain.

Deplano, M., R. Connes, J.P. Díaz, and J. Paris. 1989. Intestinal steatosis in the farm-reared sea bass Dicentrarchus labrax L. Dis. Aquat. Org. 6: 121-130.

Deplano, M., J.P. Díaz, R. Connes, M. Kentouri-Dinavach, and F. Cavalier. 1991. Appearance of lipid absorption capacities in larvae of the sea bass Dicentrarchus labrax L. during transition to the exotrophic phase. Mar. Biol. 108: 361-381

Dettlaff, T.A., A.S. Ginsburg and O.I. Schmalhausen. 1993. Sturgeon Fishes. Developmental Biology and Aquaculture. Springer-Verlag, Berlin. 300 pp.

Diaz, J.P., and R. Connes. 1997. Ontogenesis of the biliary trac in a teleost, the sea bass Dicentrarchus labrax L. Can. J. Zool. 75: 740-745.

Diaz, J.P., E. Guyot, S. Vigier, and R. Connes. 1997. First events in lipid absorption during postembryonic development of the anterior intestine in gilthead sea bream. J. Fish Biol. 51: 180-192.

Diax, J.P., E. Mani-Ponset, E. Guyot, and R. Connes. 1998. Hepatic cholestasis during the postemrbyonic development of fish larvae. J. Exp. Zool. 280: 277-287.

Domeneghini, C., R. Pannelli-Straini, and A. Veggeti. 1998. Gut glycoconjugates in Sparus aurata L. (Pisces, Teleostei). A comparative histochemical study in larval and adult ages. Histol. Histopathol.13: 359-372

Douglas, S.E., A. Gawlicka, S. Mandla, and J.W. Gallant. 1999. Ontogeny of the stomach in winter flounder: characterization and expression of the pepsinogen and proton pump genes and determination of pepsin activity. J. Fish Biol. 55: 897-915.

Douglas, S.E., S. Mandla, and J.W. Gallant. 2000. Molecular analysis of the amylase gene and its expression during the development in the winter flounder, Pleuronectes americanus. Aquaculture 190: 247-260.

Els, J.W., and R. Hennerberg. 1990. Histological features and histochemistry of the mucous glands in ventral skin of the frog (Rana fruscigula). Histol. Histopathol. 5: 345-348.

Fontagné, S., I. Geurden, A.M. Escaffre, and P. Bergot. 1998. Histological changes induced by dietary phospholipids in intestine and liver of common carp (Cyprinus carpio L.) larvae. Aquaculture 161: 213-223.

Fuiman, L.A. 1997. What can flatfish ontogey tell us about pelatic and benthic lifestyles? J. Sea Res. 37: 257-267.

Gabe, M. 1976. Histological techniques. Mason, Paris/Springer, New York.

García-, M.P., and B. Agulleiro. 1992. Ontogeny of the endocrine pancreas in sea bass (Dicentrarchus labrax). An immunocytochemical study. Cell Tissue Res. 270: 339-352.

García- M.P. M.T Lozano, and B. Agulleiro. 1994. Ontogeny of some endocrine cells of the digestive tract in sea bass (Dicentrarchus labrax). An immunocytochemical study. Cell Tissue Res. 277: 373-383.

García-Hernández, M.P., M.T. Lozano, M.T. Elbal, and B. Agulleiro. 2001. Development of the digestive tract of sea bass (Dicentrarchus labrax L.). Light and electron microscopic studies. Anat. Embryol. 204: 39-57.

Gatesoupe, F.J. 1999. The use of probiotics in aquaculture. Aquaculture 180: 147-165. 
Gisbert, E., R.H. Piedrahita, and D.E. Conklin. 2004b. Effects of delayed first feeding on the nutritional condition and mortality of California halibut larvae. J. Fish Biol. 64: 116-132.

Gisbert, E., R.H. Piedrahita, and D.E. Conklin. 2004a. Ontogenetic development of the digestive system in California halibut (Paralichthys californicus) with notes on feeding practices. Aquaculture 232: 455-470.

Gisbert, E. L. Villeneuve, J.L. Zambonino-Infante, P. Quazuguel, and C.L. Cahu. 2005. Dietary phospholipids are more efficient than neutral lipids for long chain polyunsaturated fatty acid supply in European sea bass Dicentrarchus labrax larval development. Lipids 40 (in press).

Govoni, J.J., G.W. Boechlert, and Y. Watanabe. 1986. The physiology of digestion in fish larvae. Environ. Biol. Fish. 16: 59-77.

Grau, A., S. Crespo, C. Sarasquete, and M.L. González de Canales. 1992. The digestive tract of the amberjack, Seriola dumerili Risso: A light and scanning electron microscope study. J. Fish Biol. 41: 287-303

Green, B.S., and M.I. McCormick. 1999. Influence of larval feeding history on the body condition of Amphiprion melanopus. J. Fish Biol. 55: 1273-1289.

Guyot, E., J.P. Díaz, and R.Connes. 1995. Organogenesis of the liver in sea bream Sparus aurata. J. Fish Biol. 47: 427-437.

Guyot, E., J.P. Diaz, B. Romenstand, and R. Connes. 1998.Insulin during the early postembryonic evelopment of the gilt-head sea bream, Sparus aurata: Ultrastructural, immunohistochemical, and biochemical studies. Gen. Comp. Endocrinol. 110: 147-156.

Gutiérrez, M. 1967. Coloración histológica para ovarios de peces, crustáceos y moluscos. Inv. Pesq. 31: 265-271.

Gwak, W.S., T. Seikai, and M. Tanaka 1999. Evaluation of starvation status of laboratory reared Japanese flounder Paralichthys olivaceus larvae and juveniles based on morphological and histological characteristics. Fish.Sci. 65: 339-346.

Hamlin, H.J., I.H.V. Herbing, and L.J. Kling 2000. Histological and morphological evaluations of the digestive tract and associated organs of haddock throught post-haching ontogeny. J. Fish Biol. 57: 716-732.

Henning, S.J. 1987. Functional development of the gastrointestinal tract. Pages 285-300 in L.R. Johnson, editor. Physiology of the gastrointestinal tract. $2^{\text {nd }}$ edition. Raven Press, New York.

Henning, S.J., D.C. Rubin, and R.J. Shulman. 1994. Ontogeny of the intestinal mucosa. Pages 571-610 in L.R. Johnson, editor. Physiology of the gastrointestinal tract. $3^{\text {rd }}$ edition. Raven Press, New York.

Himukai, M., T. Kono, and T. Hoshi. 1980. Age-dependent change in intestinal absorption of dipeptides and their constituent amino acids in the guinea pig. Pediatr. Res. 14: 1272-1275.

Hoehne-Reitan, K., and E. Kjorsvik. 2004. Functional development of the liver and exocrine pancreas. Am. Fish. Soc. 40: 9-36.

Holm, H., Hanssen, L.E., Krogdahl, A., Florholmen, J. 1988. High and low inhibitor soybean meals affect human duodenal proteinase activity differently: in vivo comparison with bovine serum albumin. J. Nutr. 118: 515-520.

Humason, G. 1972. Animal Tissue Techniques. 3rd edition. W.H. Freeman, San Francisco.

Izquierdo, M.S., J. Socorro, L. Arantzamendi, and C.M. Hernández-Cruz. 2000. Recent advances in nutrition in fish larvae. Fish Physiol. Biochem. 22: 97-107.

Iwai, T. 1969. Fine structure of gut epithelium cells of larval and juvenile carp during absorption of fat and protein. Arch. Histol. Jpn. 30: 183-199.

Loewe, H. and R. Eckmann. 1988. The ontogeny of the alimentary tract of coregonid larvae: normal development J. Fish Biol. 33: 841-850.

Izquierdo, M.S., J. Socorro, L. Arantzamendi, and C.M. Hernandez-Cruz. 2000. Recent advances in lipid nutrition in fish larvae. Fish Biochem. Physiol. 22: 97-107. 
Kamisaka, Y., G.K. Totland, M. Tagawa, T. Kurokawa, T. Suzuki, M. Tanaka, and I. Ronnestad. 2001. Ontogeny of cholecystokinin-immunoreactive cells in the digestive tract of Atlantic halibut, Hippoglossus hippoglossus, larvae. Gen. Comp. Endocrinol. 123: 31-37.

Kawai, S., and S. Ikeda. 1973. Studies on digestive enzymes of fishes. III. Development of the digestive enzymes of the rainbow trout after hatching and the effect of dietary change on the activities of digestive enzymes in the juvenile stage. Bull. Jap. Soc. Sci. Fish. 39: 819-823.

Kiernan, J.A. 1999. Histological and Histochemical Methods: Theory and Practice. 3rd edition, Butterworth-Heiniemann, Oxford.

Kjørsvik, E., and A.L. Reiersen. 1992. Histomorphology of yolk-sac larvae of the Atlantic halibut (Hippoglosssus hippoglossus L.) - an indication of the timing of functionality. J. Fish Biol. 41: 1-19.

Kjorsvik, E., T.M. van der Meeren, H. Kryvi, J. Arnfinnson, and P.G. Kvenseth. 1991. Early development of the digestive tract of cod larvae, Gadus morhua L., during start-feeding and starvation. J. Fish Biol. 38: 1-15

Kolkovski, S. 2001. Digestive enzymes in fish larvae and juveniles - implications and applications to formulated diets. Aquaculture 201: 181-201.

Kolkovski, S., and A. Tandler. 2000. The use of squid protein hydroloysate as a protein source in microdiets for gilthead seabream Sparus aurata larvae. Aquaculture Nutr. 6: 11-15.

Kramer, C.R., and H. Potter. 2003. Rodlet cells in the posterior intestine of embryos and neonates of two poecillid species. J. Fish Biol. 62: 1211-1216.

Krogdahl, A., and A. Sundby. 1999. Characteristics of pancreatic function in fish. Pages 437-458 in S.G. Pierzynowski and R. Zabielski, editors. Biology of the pancreas in growing animals. Elsevier Science, Amsterdam.

Kurokawa, T., and T. Suzuki. 2002. Development of neuropeptide Y-related Peptides in the digestive organs during larval stage of Japanese Flounder, Paralichthys olivaceus. Gen.Comp. Endocrinol, 126: 30-38.

Kurokawa, T., T. Suzuki., and T. Andoh. 2000. Development of cholecystokinin and pancreatic polypeptide endocrine systems during the larval stage of Japanese flounder, Paralichthys olivaceus. Gen. Comp. Endocrinol. 120: 8-16.

Kuz'mina, V.V., and A.G. Gel'man. 1998. Traits in the development of the digestive function in fishes. J. Ichthyol. 38: 106-115.

Leino, R.L. 1996 Reaction of rodlet cells to a myxosporean infection in kidney of the bluegill, Lepomis macrochirus. Can. J. Zool. 74: 217-225.

L'Hermite, A., R. Ferrano, M.P. Dubois, and A.C. Andresen. 1985. Detection of endocrine cells by immunofluorescnce method in gastroenteropancreaticsystem of the adult eel, glass eel and leptocephalic larva (Anguilla anguilla, L.). Gen. Comp. Endocrinol. 58: 347-359

Lodja, Z., R. Gossrau, and T.H. Schiebler. 1979. Enzyme Histochemistry: A Laboratory Manual. New York: Springer-Verlag.

Luna, L.G. 1968. Manual of Staining Methods of the AFIP. 3rd edition, New York, McGraw-Hill.

Luizi, F.S., B. Gara, R.J.Shields, and N.R.Bromage. 1999. Further description of the development of the digestive organs in Atlantic halibut (Hippoglossus hippoglossus) larvae, with notes on differential absorption of copepod and Artemia prey. Aquaculture 176: 101-116

Ma, P., B. Sivaloganathan, P.K. Reddy, W.K. Chan, and T.J. Lam. 2001. Ontogeny of $\square$-amylase gene expression in sea bass larvae (Lates Calcarifer). Mar. Biotechnol. 3: 463-469.

Ma H., C. Cahu J. Zambonino H. Yu, Q. Duan, M.M Le Gall, and K. Mai. 2005. Activities of selected digestive enzymes during larval development of large yellow croaker (Pseudosciaena crocea). Aquaculture 245: 239-248.

Mai, K., H. Yu, H. Ma, Q. Duan, C.L. Cahu, E. Gisbert, and J.L. Zambonino Infante. 2005. A histological study on the development of the digestive tract of large yellow croaker (Pseudoscianea crocea) larvae and juveniles. J. Fish Biol. (in press) 
Manera, E., B. Simoni, and S. Dezfuli. 2001. Effect of dexamethasone administration on occurrence and ultrastructure of rodlet cells in Carassius auratus L. with particular reference to bulbus arteriosus. J. Fish Biol. 59: 1239-1248.

Margulies, D. 1993. Assessment of the nutritional condition of larval and early juvenile tuna and Spanish mackerel (Pisces: Scombridae) in the Panamá Bight. Mar. Biol. 115: 317-330.

Maroux, S., Louvard, D., Baratti, J. 1973. The aminopeptidase from hog-intestinal brush border. Biochem. Biochim. Acta 321: 282-295.

Martinez, I., F.J. Moyano, C. Fernandez-Diaz, and M. Yufera. 1999. Digestive enzyme activity during larval development of the Senegal sole (Solea senegalensis). Fish Physiol. Biochem. 21: 317323.

Martoja, R., and M. Martoja-Pierson. 1970. Teécnicas de Histologia Animal. Barcelona: Toray Masson S.A.

Marza, E., C. Barthe, M. André, L. Villeneuve, C. Hélou, and P. Babin. 2005. Developmental expression and nutritional regulation of a zebrafish gene homologous to mammalian microsomal triglyceride transfer protein large subunit. Dev. Dynam. 232: 506-518.

Méndez, E.; A., Smith; M.L., Figeiredo-Garutti, J.V. Planas, I. Navarro, and J. Gutiérrez. 2001. Receptors for IGF-I predominate over insulin receptors in skeletal muscle throughout the life cycle of brown trout.Gen. Comp. Endocrinol. 122: 148-157

Métais, P. and Bieth, J. 1968. Determination de l'a-amylase par une microtechnique. Ann. Biol. Clin. 12:133-142.

Micale, V., M. Garaffo, L. Genovese, M.T. Spedicato, and U. Muglia. 2005. The ontogeny of the alimentary tract during larval development in common pandora Pagellus eryhtrinus L. Aquaculture (in press).

Moon, T.W., and I.A. Johnston. 1980. Starvation and the activities of glycolytic and gluconeogenetic enzymes in skeletal muscles and liver of plaice, Pleuronectes platessa. J. Comp. Physiol. 136: 31-38

Morais, S., C. Cahu, J.L. Zambonino-Infante, J. Robin, I. Rønnestad, M.T. Dinis, and L.E.C. Conceição. 2004. Dietary triacylglycerol source and level affects performance and lipase expression in larval seabass (Dicentrarchus labrax). Lipids 39: 449-458.

Morrison, C.M. 1993. Histology of the Atlantic cod, Gadus morhua: an atlas. Part four: eleutheroembryo and larva. Canadian Special Publication of Fisheries and Aquatic Sciences 119. 496 pp.

Moyano, F.J., Díaz, M., Alarcon, F.J. and Sarasquete, C. 1996. Characterization of digestive enzyme activity during larval development of gilthead seabream, Sparus aurata L. Fish Phisiol. Biochem. 15: 121-130.

Nicholson, J.A., Kim, Y.S. 1975. A one-step L-amino acid oxidase assay for intestinal peptide hydrolase activity. Anal. Biochem. 63: 110-117.

Olsen, R. E., R. Myklebust, E. Ringo, and T.M. Mayhew. 2000. The influences of dietary linseed oil and saturated fatty acids on caecal enterocytes in Artic charr (Salvelinus alpinus L.): a quantitative ultrastructural study. Fish Physiol. Biochem. 22: 207-216.

Oozeki, Y., T. Ishii, and R. Hirano. 1989. Histological study of the effects of starvation on reared and wild-caught larval stone flounder Kareius bicoloratus. Mar. Biol. 100: 269-276.

Ortíz-Delgado, J.B., M. Darias, J.P. Cañabate, M. Yúfera, and Sarasquete, C. 2003. Organogenesis of the digestive tract in the white seabream, Diplodus sargus. Histological and histochemical approaches. Histol. Histopathol. 18: 1141-1154.

Ostos-Garrido, M.V., M.I. Nuñez-Torres, and M.A. Abaurrea-Equisoain. 1993. Histological, histochemical and ultrastructural analysis of the gastric mucosa in Oncorhynchus mykiss. Aquaculture 115: 121-132.

Ozkizilcik, S., F.L. Chu, and A.R. Place. 1996. Ontogenetic changes of lipolytic enzymes in striped bass (Morone saxatilis). Comp. Biochem. Physiol. 113B: 631-637. 
Pearse, A.G.E. 1985. Histochemistry. Theoretical and Applied. Vol. 2. Analytic Technology. New York: Churchill Livingstone.

Pedersen, B.H., and K.P. Andersen. 1992. Induction of trypsinogen secretion in herring larvae (Clupea harengus). Mar. Biol. 112: 559-565.

Peña, R., S. Dumas, M. Villalejo-Fuerte, and J.L. Ortíz-Galindo. 2003. Ontogenetic development of the digestive tract in reared spotted sand bass Paralabrax maculatofasciatus larvae Aquaculture 219: 633-644.

Péres, A., C.L. Cahu, J.L. Zambonino Infante, M.M. Legall, and P. Quazuguel. 1996. Amylase and trypsin responses to intake of dietary carbohydrate and protein depend on the developmental stage in sea bass (Dicentrarchus labrax) larvae. Fish Physiol. Biochem. 15: 237-242.

Péres, A., C.L. Cahu, and J.L. Zambonino Infante. 1997. Dietary spermine supplementation induces intestinal maturation in sea bass (Dicentrarchus labrax) larvae. Fish Physiol. Biochem. 16: 479-485.

Péres, A., J.L. Zambonino Infante, and C.L. Cahu. 1998. Dietary regulation of activities and mRNA levels of trypsin and amylase in sea bass (Dicentrarchus labrax) larvae. Fish Physiol. Biochem. 19:145-152.

Reinecke, M., C. Müller, and H. Segner. 1997. An immunohistochemical analysis of the ontogeny, distribution and coexistence of 12 regulatory peptides and serotonin in endocrine cells and nerve fibers of the digestive tract of the turbot, Scophthalmus maximus (Teleostei). Anat. Embryol. 195: 87102.

Ribeiro, L., C. Sarasquete, and M.T. Dinis. 1999a. Histological and histochemical development of the digestive system of Solea senegalensis (Kaup 1858) larvae. Aquaculture 171: 293-308.

Ribeiro, L., J.L. Zambonino Infante, C. Cahu, and M.T. Dinis. 1999b. Development of digestive enzymes in larvae of Solea senegalensis, Kaup 1858. Aquaculture 179: 465-473.

Rønnestad, I., A. Thorsen, and R. Finn. 1999. Fish larval nutrition: a review of recent advances in the role of amino acids. Aquaculture 177: 201-216.

Rust, M.B. 2002. Nutritional Physiology. Pages 454-504 in J.E. Halver, and R.W. Hardy, editors. Fish Nutrition, $3^{\text {rd }}$ Edition. Academic Press, San Diego, California.

Santamaría, C.A., M. Marin de Mateo, R. Traveset, R. Sala, A. Grau, E. Pastor, C. Sarasquete, and S. Crespo. 2004. Larval organogenesis in common dentex, Dentex dentex L. (Sparidae): histological and histochemical aspects. Aquaculture 237: 207-228

Sarasquete, C., and M. Gutiérrez. 2005. New tetrachromic VOF stain (Type III-G.S) for normal and pathological fish tissues. Eur. J. Histochem. 49: 105-114.

Sarasquete, C., A. Polo, and M.L. González de Canales. 1993. A histochemical and immunohistochemical study of digestive enzymes and hormones during the larval development of the seabream Sparus aurata L. Histochem. J. 25: 430-437

Sarasquete, C., A. Polo, and Yúfera, M. 1995. Histology and histochemistry of the development of the digestive system of larval gilthead seabream, Sparus aurata L. Aquaculture 130: 79-92

Sarasquete, C., M.L. Gonzales de Canales, J.M. Arellano, J.A. Muñoz-Cueto, L. Ribeiro, and M.T. Dinis. 1996. Histochemical aspects of the yolk-sac and digestive tract of larvae of the Senegal sole, Solea senegalensis (Kaup, 1858). Histol. Histopathol. 11: 881-888.

Sarasquete, C., E. Gisbert, L. Ribeiro, L. Vieira, and M.T. Dinis. 2001. Glyconjugates in epidermal, branchial and digestive mucous cells and gastric glands of gilthead sea bream, Sparus aurata, Senegal sole, Solea senegalensis and Siberian sturgeon, Acipenser baeri development. Eur. J.Histochem. 45: 267-278.

Sargent, J.R., L. McEvoy, A Estévez,. G. Bell., M. Bell, J. Henderson, and D. Tocher. 1999. Lipid nutrition in marine fish during early development: current status and future directions. Aquaculture 79: 217-230.

Sargent, J.R., D.R. Tocher, and J.B. Bell. 2002. The lipids. Pages 182-257 in J.E. Halver and R.W. Hardy, editors. Fish Nutrition, third edition. San Diego: Academic Press. 
Segner, H., R. Rösch, J. Verreth, and U. Witt. 1993. Larval nutritional physiology: studies with Clarias gariepinus, Coregonus lavaretus L. World Aquac. 21: 121-134.

Segner, H., V. Storch, M. Reinecke, W. Kloas, and W. Hanke.1994. The development of functional digestive and metabolic organs in turbot, Scophthalmus maximus. Mar. Biol. 119: 471-486.

Segner, H., V. Sotrch, M. Reinecke, W. Kloas, and W. Hanke. 1995. A tabular overview of organogenesis in larval turbot (Scopthalmus maximus L.). ICES Mar. Sci. Symp. 201: 35-39.

Scocco, P., D. Accili, G. Menghi, and P. Ceccarelli. 1998. Unusual glycoconjugates in the oesophagus of a tilapine polyhybrid. J. Fish Biol. 53: 39-48.

Sheele, G.A. 1993. Regulation of pancreatic gene expression in response to hormones and nutritional substrates. Pages 103-120 in V.L. GO, J.D. Gardner, F.P. Brooks, and E. Lebenthal, editors. The pancreas: biology, pathobiology, and disease. $2^{\text {nd }}$ edition. Raven Press, New York.

Sheridan, M.A. 1988 Lipid dynamics in fish: aspects of absorption, transportation, deposition and mobilization. Comp. Biochem. Physiol. 90B: 679-690

Shield, R.J., J. Bell, F.S. Luizi, B. Gara, N. Bromage, and J.R. Sargent. 1999. Natural copepods are superior to enriched Artemia nauplii as feed for halibut larvae (Hippoglossus hippoglossus) in terms of survival, pigmentation and retinal morphology: relation to dietary essential fatty acids. Journal of Nutrition 129: 1186-1194.

Smit, H. 1961. Gastric secretion in the lower vertebrates and birds. Pages 2791-2805 in Code, C. F., editor, Handbook of physiology. Alimentary Canal, Vol. 6, American Physiological Society, Washington D.C.

Smith, L.S. 1989. Digestive functions in teleost fishes. Pages 331-421 in Harver, J.E., editor, Fish Nutrition, 2nd Edition, Academic Press, San Diego, California..

Smith, A., S. Chan, and J. Gutiérrez. 2005. Autoradiographic and immunohistochemical localization of insulin-like growth factor-I receptor binding sites in brain of the brown trout, Salmo trutta. Gen. Comp Endocrinol. 141: 203-213.

Snipes, R.L. 1977. Limited fat absorption in the large intestine of mice. A morphological study. Acta Anat. 99: 435-439.

Srivastava, A.S, T. Kurokawa, and T. Suzuki. 2002. mRNA expression of pancreatic enzyme precursors and estimation of protein digestibility in first feeding larvae of the Japanese flounder, Paralichthys olivaceus. Comp. Biochem. Physiol. 132A: 629-635.

Stroband, H.W.J., H.V.D. Meer, and L.P.M. Timmermans. 1979. Regional functional differentiation in the gut of the grass-carp, Ctenopharyngodon idella. Histochem. 64: 235-249

Tabor, C.W., and H. Tabor. 1984. Polyamines. Ann Rev Biochem 53: 749-790.

Tanaka, M. 1971. Studies on the structure and function of the digestive system in teleost larvae. III. Development of the digestive system during postlarval stage. Jap. J. Ichthyol. 18: 164-174.

Terjensen, B.F., T.D. Chadwick, J.A.J. Verreth, I. Rønnestad, and P.A. Wright. 2001. Pathways for urea production during early life of an air-breathing teleost, the African catfish Clarias gariepinus Burchell. J. Exp. Biol. 204: 2155-2165.

Terjensen, B.F., R.N. Finn, B. Norberg, and I. Rønnestad. 2002. Kinetics and fates of ammonia, urea, and uric acid during oocyte maturation and ontogeny of the Atlantic halibut (Hippoglossus hippoglossus L.). Comp. Biochem. Physiol. 131A: 443-455.

Theilacker, G.H. \& Watanabe, Y. 1989. Midgut cell height defines nutritional status of laboratory raised larval northern anchovy, Engraulis mordax. Fishery Bulletin 87, 457-469.

Theilacker G.H., and S.M. Porter. 1995. Condition of larval walleye pollock Theragra chalcogramma, in the Western Gulf of Alaska, assessed with histological and shrinkage indices. Fish. Bull. 93: 333-344.

Theilacker, G.H., Bailey, K.M., Canino, M.F. \& Porter, S.M. 1996. Variations in larval walleye pollock feeding and condition: a synthesis. Fish. Ocean. 5: 112-123.

Tytler P., and J.H.S. Blaxter. 1988. Drinking in yolk sac stage larvae of the halibut (Hippoglossus hippoglossus L.). J. Fish Biol. 32,493^494. 
Tovar-Ramirez, D., J.L. Zambonino Infante, C. Cahu, F.J. Gatesoupe, and R. Vazquez-Juarez. 2004. Influence of dietary live yeast on European sea bass (Dicentrarchus labrax) larval development. Aquaculture 234: 415-427.

Veggeti, A., A. Rowlerson, G. Radaelli, S. Arrighi, and C. Domeneghini. 1999. Post-hatching development of the gut and lateral muscle in the sole, Solea solea. J. Fish Biol. 55: 44-65.

$\mathrm{Vu}$, T.T. 1983. Etudes histoenzymologique des activités protéasiques dans le tube digestif des alrves et des adultes de bar, Dicentrarchis labrax. Aquaculture 32: 57-69.

Walford, J., and T.J. Lam. 1993. Development of the digestive tract and proteolytic enzyme activity in seabass (Lates calcarifer) larvae and juveniles. Aquaculture 109: 187-205.

Worthington, T.M. 1982. Enzymes and related biochemicals. Biochemical Product Division. Worthington Diagnostic System Inc. Freehold, New Jersey.

Wright, P.A., A. Felskie, P.M. Anderson. 1995. Induction of ornithine-urea cycle enzymes and nitrogen metabolism and excretion in rainbow trout (Oncorhynchus mykiss) during early life stages. J. Exp. Biol. 198: 127-135.

Yúfera, M., E. Pascual, A. Polo, and M.C. Sarasquete. 1993. Effect of starvation on the feeding ability of gilthead seabream (Sparus aurata L.) larvae at first feeding. J. Exp. Mar. Biol. Ecol. 169: 259272.

Yufera, M., C. Sarasquete, and C. Fernández-Diaz. 1996. Testing protein-walled microcapsules for the rearing of first-feeding gilthead seabream, Sparus aurata L. Mar. Fresh Water Res. 47: 211-216.

Zambonino Infante, J.L., and C.L. Cahu. 1994. Influence of diet on pepsin and some pancreatic enzymes in sea bass (Dicentrarchus labrax) larvae. Comp. Biochem. Physiol. 109A: 209-212.

Zambonino Infante, J.L., C.L. Cahu, and A. Peres. 1997. Partial substitution of di- and tripeptides for native proteins in sea bass diet improves Dicentrarchus labrax development. J. Nutr. 127: 608-614.

Zambonino Infante, J.L., and C.L. Cahu. 1999. High dietary lipid levels enhance digestive tract maturation and improve Dicentrarchus labrax larval development. J. Nutr. 129: 1195-1200.

Zambonino Infante, J.L., and C.L. Cahu. 2001. Ontogeny of the gastrointestinal tract of marine fish larvae. Comp. Biochem. Physiol. 130C: 477-487.

Zimmer, G., G. Reuter, and R: Schauer. 1992. Use of influenza c-virus for detection of 9-oacetylated sialic acids on immobilised conjugates by esterase activity. Eur. J. Biochem. 204: 209-215. 
Table 1. Spectrophotometric methods commonly used for digestive enzyme assays.

\begin{tabular}{|c|c|c|c|c|c|}
\hline Enzyme & Substrate/Temp. & $\begin{array}{l}\text { Buffer/ } \\
\text { Color developer }\end{array}$ & $\begin{array}{c}\lambda \\
\mathrm{nm}\end{array}$ & $\begin{array}{l}\text { Extinction } \\
\text { coefficient } \\
1 / \mu \mathrm{mol} / \mathrm{cm}\end{array}$ & Reference \\
\hline Amylase & $\begin{array}{l}\text { Starch }(3 \mathrm{~g} / \mathrm{l}) \\
\text { in } \mathrm{NaH}_{2} \mathrm{PO}_{4} 66 \mathrm{mM}, \mathrm{pH}=7.4 \\
-37^{\circ} \mathrm{C}\end{array}$ & Iodine $\mathrm{N} / 3000$ & 580 & not a kinetic & Métais and Bieth, 1968 \\
\hline Chymotrypsine & $\begin{array}{l}\text { Benzoyl Tyrosine Ethyl } \\
\text { Ester } 50 \mathrm{mM}, 25^{\circ} \mathrm{C}\end{array}$ & $\begin{array}{l}\text { TrisHCl } 80 \mathrm{mM} \\
\mathrm{CaCl}_{2} 100 \mathrm{mM} \\
\mathrm{pH}=7.8\end{array}$ & 256 & 0.0102 & Worthingthon, 1982 \\
\hline Trypsine & $\begin{array}{l}\text { N-Benzoyl-DL-p- } \\
\text { nitroanilide } 0.1 \mathrm{M} \\
25^{\circ} \mathrm{C}\end{array}$ & $\begin{array}{l}\text { TrisHCl 100mM, } \\
\mathrm{CaCl}_{2} 20 \mathrm{mM}, \\
\mathrm{pH}=8.2\end{array}$ & 407 & 0.0082 & Holm et al., 1984 \\
\hline Lipase & $\begin{array}{l}\text { p-nitrophenylmyristate } \\
0.53 \mathrm{mM} \text {, sodium cholate } \\
5 \mathrm{mM}, 30^{\circ} \mathrm{C}\end{array}$ & $\begin{array}{l}\text { Tris-HCl } 0.25 \mathrm{M}, \\
\mathrm{pH}=9\end{array}$ & 407 & 0.163 & Iijima et al., 1998 \\
\hline $\begin{array}{l}\text { Alkaline } \\
\text { Phosphatase }\end{array}$ & $\begin{array}{l}\text { p-nitrophenylphosphate } \\
5 \mathrm{mM}, 37^{\circ} \mathrm{C}\end{array}$ & $\begin{array}{l}\mathrm{NaHCO}_{3} 30 \mathrm{mM}, \\
\mathrm{pH}=9.8\end{array}$ & 407 & 0.0183 & Bessey et al., 1946 \\
\hline Aminopeptidase $\mathrm{N}$ & $\begin{array}{l}\text { L-Leucine p-nitroanilide } \\
0.1 \mathrm{M}, 37^{\circ} \mathrm{C}\end{array}$ & $\begin{array}{l}\mathrm{H}_{2} \mathrm{PO}_{4} 80 \mathrm{mM}, \\
\mathrm{pH}=7\end{array}$ & 407 & 0.0082 & Maroux et al. 1973 \\
\hline $\begin{array}{l}\text { Leucine-alanine } \\
\text { peptidase }\end{array}$ & $\begin{array}{l}\text { Leu-Ala } 10 \mathrm{mM} \text { in TrisHCl } \\
50 \mathrm{mM} \mathrm{pH}=8,37^{\circ} \mathrm{C}\end{array}$ & O-dianisidine & 530 & not a kinetic & Nicholson and Kim, 1975 \\
\hline
\end{tabular}

$\lambda .:$ wavelength; Temp: Temperature 
Table 2. Histochemical reactions used to detect proteins in paraffin sections.

\begin{tabular}{|c|c|}
\hline Reactions & Functions and/or detected compounds \\
\hline Bromophenol Blue- $\mathrm{Hg}$ & Proteins in general \\
\hline Ninhydrin-Schiff & Proteins rich in lysine $(-\mathrm{NH} 2)$ \\
\hline Deamination-Ninhydrin-Schiff & Lysine blockage \\
\hline Ferric ferricyanide (Fe III) & $\begin{array}{l}\text { Proteins rich in cysteine (-SH-groups) and } \\
\text { other reductor groups }\end{array}$ \\
\hline $\begin{array}{l}\mathrm{N} \text { - ethylmaleimide }\left(\mathrm{Cl}_{2} \mathrm{Hg}\right) \text { - potassium } \\
\text { ferricyanide } \mathrm{Fe}(\mathrm{III})\end{array}$ & Cysteine and $\mathrm{SH}$ blockage \\
\hline $\begin{array}{l}\text { Thioglyollic acid-potassium ferricyanide (Fe } \\
\text { III) }\end{array}$ & Proteins rich in cystine (-S-S-groups) \\
\hline $\begin{array}{l}\text { 1,2 Naphtoquinone-4-sulphonic acid, sodium } \\
\text { salt }\end{array}$ & Proteins rich in arginine \\
\hline Benzyl-NQS & Arginine blockage \\
\hline Hg suphate-sulphuric acid sodic nitrate & Proteins rich in tyrosine \\
\hline Baker's iodination & Tyrosine blockage \\
\hline p-Dimethylaminobenzaldehyde & Proteins rich in tryptophan \\
\hline
\end{tabular}


Table 3. Histochemical reactions used to detect carbohydrates in paraffin sections.

\begin{tabular}{|c|c|}
\hline Reactions & Functions and/or detected compounds \\
\hline Periodic acid-Schiff (PAS) & $\begin{array}{l}\text { Aldehydes derived from the oxidation of adjacent glycol or } \\
\alpha \text {-amino-alcohol groups }\end{array}$ \\
\hline Diastase-PAS & $\begin{array}{l}\text { Glycogen, neutral mucosubstances and/or glycoconjugates } \\
\text { and/or glycolipids }\end{array}$ \\
\hline $\mathrm{KOH}-\mathrm{PAS}$ & $\begin{array}{l}\text { Aldehydes derived from the Saponification and oxidation } \\
\text { of adjacent glycol or } \alpha \text {-amino-alcohol groups }\end{array}$ \\
\hline Alcian Blue $\mathrm{pH} 2.5$ & Carboxyl-rich glycoconjugates (sulphated or not) \\
\hline Alcian Blue pH 1.0 & Sulphated glycoconjugates (weakly ionised) \\
\hline Alcian Blue $\mathrm{pH} 0.5$ & Sulphated glycoconjugates (strongly ionised) \\
\hline Esterification / Alcian Blue $\mathrm{pH} 2.5$ & Blockage of carboxylated glycoconjugates \\
\hline $\begin{array}{l}\text { Esterification / Saponification/ } \\
\text { Alcian Blue pH } 2.5\end{array}$ & Reactivation of carboxylated glycoconjugates \\
\hline Esterification/ Alcian Blue pH 0.5 & Loss of sulphated groups of glycoconjugates (sulphation) \\
\hline $\begin{array}{l}\text { Esterification / Saponification / } \\
\text { Alcian Blue pH } 0.5\end{array}$ & $\begin{array}{l}\text { Un-reactivation of alcianophilia due to sulphation of } \\
\text { glycoconjugates }\end{array}$ \\
\hline $\begin{array}{l}\text { Alcian Blue pH 0.5/ Yellow Alcian } \\
\text { pH } 2.5\end{array}$ & $\begin{array}{l}\text { Carboxylated mucins (yellow), sulphated mucins (blue), } \\
\text { both (green) }\end{array}$ \\
\hline Acid hydrolysis- Alcian Blue pH 2.5 & Sialic acid extraction (supression of glycosidic bonds) \\
\hline Alcian Blue pH 2.5/ PAS & Acid mucins (blue), neutral mucins (magenta) \\
\hline Toluidine Blue & Basophilia or Metachromasia \\
\hline WGA (GlcNAc/NANA) & $\mathrm{N}$-acetylglucosamine and/or Sialic acid \\
\hline Neuraminidase/WGA & Extraction of terminal NANA residues \\
\hline Con A (Man/Glc) & Mannose and/or Glucose \\
\hline DBA (GalNAc) & $\mathrm{N}$-acetylgalactosamine \\
\hline
\end{tabular}


Table 4. Histochemical reactions used to detect lipids in cryostat sections.

Reactions

Red Oil O

Bromination/ Red Oil O

Bromination/ Acetone / Red Oil O

Black Sudan B

Bromination/ Black Sudan B

Bromination/ Acetone / Black Sudan B

Nile blue

Nile Blue sulphate

Ferric - Haematoxylin

Rubeanic acid

Osmium Tetroxide

Pyridine or Chloroform-Methanol

Cold anhydrous Acetone

Methanol-Chloroform-HCl

Acid Hydrolysis - Black Sudan B

\section{Functions and/or detected compounds}

Hydrophobic lipids (neutral fat, glycerids, wax, etc)

Fat, phosphoglycerides, cholesterol. Insolubilization of unsaturated lipids in organic solvents.

Neutral lipids extraction

Hydrophobic and hydrophilic lipids (triglycerids, fatty acids, cholesterol esters, phospholipids)

Fat, cholesterol, fatty acids, phospholipids, etc.

Insolubilization of unsaturated lipids

Hydrophobic lipids extraction

Acidic lipids and basophilia (blue), unsaturated and neutral lipids (pink)

Phospholipids and free fatty acids blue-purple, unsaturated hydrophobic lipids pink

Phospholipids

Free fatty acids

Unsaturated lipids

Extraction of lipids except lipoproteins

Extraction of hydrophobic lipids

Extraction of lipids including the phospholipid moieties of lipoproteins

Unmasked lipids/lipoproteins 
Table 5. Histochemical reactions used to detect enzymes in cryostat sections.

\begin{tabular}{ll}
\hline Reactions & Functions and/or detected compounds \\
\hline Sodium $\beta-$ glycerophasphate & Alkaline phosphatase (brown-black) \\
Sodium B - glycerophasphate & Acid phosphatase (brown) \\
L - leucyl-2-naphthylamide pH 6.5 & Aminopeptidase M (brown-black) \\
1-naphthyl-acetate & Nonspecific esterase (brown-black) \\
Tween 80 5\% & Lipase (black-brown) \\
Adenosine triphosphate salt (pH 9.4) & Muscular ATPase (brown-black) \\
Adenosine triphosphate salt (pH 7.2) & Membranous ATPase (brown-black) \\
\hline
\end{tabular}


Table 6. The ontogeny of buccopharyngeal and oesophageal goblet cells in different marine fish larvae.

$\begin{array}{cccc}\text { Rearing } & \text { Buccopharynx } \\ \text { temperature } & (\mathrm{dph}) & \begin{array}{c}\text { Oesophagus } \\ (\mathrm{dph})\end{array} & \text { Reference } \\ \left({ }^{\circ} \mathrm{C}\right) & & & \end{array}$

Gadiformes

\section{Gadidae}

$\begin{array}{lcccl}\text { Gadus morbua } & 6-7 & \mathrm{np} & 11 & \text { Morrison (1993) } \\ \text { Melanogrammus aaeglefinus } & 7.5-8.5 & \mathrm{np} & 12 & \text { Hamlin et al. (2000) }\end{array}$

Perciformes

\section{Moronidae}
Dicentrarchus labrax
18-19
np
5-9
García-Hernández et al. (2001)

\section{Serranidae}

Paralabrax maculatofasciatus

np

6

Peña et al. (2003)

\section{Sciaenidae}

Psendosciaena crocea

3

4-5

Mai et al. (2005)

Sparidae

Dentex dentex
Diplodus sargus
Pagellus erythrinus
Pargus pargus
Sparus aurata

16-20

19.5

np

7

Santamaría et al. (2004)

18.5-20

$\mathrm{np}$

6

Ortiz et al. (2003)

19.5

9-11

9-11

Micale et al. (2005)

Sparus aurata

19.5

np

6

Darias (2005)

4-6

$7-8 / 34$

Sarasquete et al. (1995)

Domeneghini et al. (1998)

Pleuronectiformes

\section{Soleidae}

$\begin{array}{lccll}\text { Solea senegalensis } & 17-19 & 5 & 3 & \text { Ribeiro et al. (1999) } \\ \text { Solea solea } & 19 & 2 & 2 & \text { Bouhlic and Gabaudan (1992) }\end{array}$

\section{Paralichthydae}

$\begin{array}{lcccl}\text { Paralichthys californicus } & 18 & 10-11 & 9 & \text { Gisbert et al. (2004) } \\ \text { P. dentatus } & 20 & 3 & 3 & \text { Bisbal and Bengtson (1995) }\end{array}$

\section{Pleuronectidae}

Pleuronectes ferruginea

8-10

7

12

Baglogle et al. (1997)

\section{Scopthalmidae}

Scophthalmus maximus

$18-20$ 
Table 7. Ontogeny of the stomach in different marine fish larvae.

\begin{tabular}{cccc}
\hline Rearing & Appearance of \\
temperature & first gastric \\
$\left({ }^{\circ} \mathrm{C}\right)$ & glands (dph) & $\begin{array}{c}\text { Sompletion } \\
\text { comph }\end{array}$ & Reference \\
\hline
\end{tabular}

Gadiformes

Gadidae

$\begin{array}{lccll}\text { Gadus morbua } & 6-7 & 52 & 62-70 & \text { Morrison (1993) } \\ \text { Melanogrammus aeglefinus } & 7.5-8.5 & 33 & 50-53 & \text { Hamlin et al. (2000) }\end{array}$

Perciformes

Moronidae
Dicentrarchus labrax
$18-19$
55
60
García-Hernández et al. (2001)

Serranidae

Paralabrax maculatofasciatus

25

16

22

Peña et al. (2003)

\section{Sciaenidae}

Pseudosciaena crocea

24

21

$30 \quad$ Mai et al. (2005)

Sparidae

$\begin{array}{lcccl}\text { Dentex dentex } & 16-20 & 22 & 36 & \text { Santamaría et al. (2004) } \\ \text { Diplodus sargus } & 19.5 & 13-15 & 30-33 & \text { Ortiz-Delgado et al. (2003) } \\ \text { Pagellus erythrinus } & 18.5-20 & 28 & 41 & \text { Micale et al. (2005) } \\ \text { Pargus pargus } & 19.5 & 26-30 & 35 & \text { Darias (2005) } \\ \text { Sparus aurata } & 18-20 & 45 & 70-100 & \text { Domeneghini et al. (1998) }\end{array}$

Pleuronectiformes

\section{Soleidae}

$\begin{array}{lcccl}\text { Solea senegalensis } & 17-19 & 25-30 & 37-40 & \text { Ribeiro et al. (1999) } \\ \text { Solea solea } & 19 & 22 & 30 & \text { Bouhlic and Gabaudan (1992) }\end{array}$

Paralichthydae

$\begin{array}{lcccl}\text { Paralichthys californicus } & 18 & 23 & 27-30 & \text { Gisbert et al. (2004) } \\ \text { P. dentatus } & 20 & 31 & \mathrm{np} & \text { Bisbal and Bengtson (1995) }\end{array}$

Pleuronectidae

Hippoglossus hippoglossus

$11 \quad 35$

Pleuronectes ferruginea

8-10

29-36

50

Luizi et al. (1999)

Scopthalmidae

Scophthalmus maximus

16-20

$15-20$

20-35

Segner et al. (1994)

Note: Abbreviation, np: Information not provided in the study. 
Table 8. Ontogeny of the intestine, appearance of functional goblet cells and intestinal valve formation, in different marine fish larvae.

\begin{tabular}{|c|c|c|c|c|}
\hline & $\begin{array}{c}\text { Rearing } \\
\text { temperature } \\
\left({ }^{\circ} \mathrm{C}\right)\end{array}$ & $\begin{array}{c}\text { Intestinal } \\
\text { valve } \\
\text { (dph) }\end{array}$ & $\begin{array}{l}\text { Appearance } \\
\text { of goblet } \\
\text { cells (dph) }\end{array}$ & Reference \\
\hline \multicolumn{5}{|l|}{ Gadiformes } \\
\hline \multicolumn{5}{|l|}{ Gadidae } \\
\hline Gadus morbua & $6-7$ & 3 & $62-70$ & Morrison (1993) \\
\hline Melanogrammus aeglefinus & $7.5-8.5$ & 2 & 18 & Hamlin et al. (2000) \\
\hline \multicolumn{5}{|l|}{ Perciformes } \\
\hline \multicolumn{5}{|l|}{ Moronidae } \\
\hline Dicentrarchus labrax & $18-19$ & 5 & $13-15$ & García-Hernández et al. (2001) \\
\hline \multicolumn{5}{|l|}{ Serranidae } \\
\hline Paralabrax maculatofasciatus & 25 & 2 & 5 & Peña et al. (2003) \\
\hline \multicolumn{5}{|l|}{ Sciaenidae } \\
\hline Pseudosciaena crocea & 24 & $2-3$ & 11 & Mai et al. (2005) \\
\hline \multicolumn{5}{|l|}{ Sparidae } \\
\hline Dentex dentex & $16-20$ & $4-5$ & 18 & Santamaría et al. (2004) \\
\hline Diplodus sargus & 19.5 & $2-3$ & 15 & Ortiz-Delgado et al. (2003) \\
\hline Pagellus erythrinus & $18.5-20$ & 3 & 33 & Micale et al. (2005) \\
\hline Pargus pargus & 19.5 & $2-3$ & np & Darias (2005) \\
\hline Sparus aurata & $18-20$ & $4-6$ & $14 / 35$ & Sarasquete et al. (1995) \\
\hline & & & & Domenegini et al. (1998) \\
\hline
\end{tabular}

Pleuronectiformes

\section{Soleidae}

$\begin{array}{lcccl}\text { Solea senegalensis } & 17-19 & 2-3 & 3-4 & \text { Sarasquete et al. (1996) } \\ \text { Solea solea } & 19 & 2 & 3 & \text { Bouhlic and Gabaudan (1992) }\end{array}$

Paralichthydae

$\begin{array}{lcccl}\text { Paralichthys californicus } & 18 & 1-2 & 13 & \text { Gisbert et al. (2004) } \\ \text { P. dentatus } & 20 & 3 & \mathrm{np} & \text { Bisbal and Bengtson (1995) }\end{array}$

Pleuronectidae

Pleuronectes ferruginea

$8-10$

7

10

Baglogle et al. (1997)

Scopthalmidae 
Note: Abbreviation, np: Information not provided in the study.

Table 9. Cell immunoreactivity and organization during endocrine pancreas development

in European sea bass. SST: somatostatin; G: glucagons; PP: pancreatic polypeptide; +: immunreactivity in cells; -: no immunoreactivity (Data from García and Agulleiro, 1992)

\begin{tabular}{|c|c|c|c|c|c|c|}
\hline \multirow[t]{2}{*}{ Age (days) } & \multirow[t]{2}{*}{ Cell organization } & \multicolumn{5}{|c|}{ Peptide like immunoreactivity } \\
\hline & & Insulin & SST-25 & SST-14 & G & PP \\
\hline Hatching & A primordial cord & + & + & + & - & - \\
\hline $2-5$ & A primitive islet & + & + & + & - & - \\
\hline 9 & A single islet & + & + & + & + & - \\
\hline \multirow{2}{*}{25} & A big islet & + & + & + & + & + \\
\hline & A primordial islet & + & + & - & - & - \\
\hline \multirow{3}{*}{$55-61$} & A big islet & + & + & + & + & + \\
\hline & An intermediate islet & + & + & + & + & + \\
\hline & Several small islets & + & + & + & + & + \\
\hline
\end{tabular}




\section{Figure captions}

Figure 1. Dissection and tissue processing of European sea bass larvae in order to assay pancreatic and intestinal enzymes.

Figure 2. Detail of the goblet cells containing carboxyl-rich glycoconjugates (Alcian Blue PH 2.5 positive) in the posterior region of the buccopharynx (B) and anterior oesophagus (OE) in a 13 days post hatch larva of white seabream (Diplodus sargus). Note that cartilage is also staining with the $\mathrm{AB}$ pH 2.5. Staining technique: Alcian Blue PH 2.5 without counterstaining.

Figure 3. Detail of posterior region of the buccopharynx in a 25 days post hatch larva of California halibut (Paralichthys californicus). Inner picture: detail of fungiform (arrow) and filiform (asterisk) buccopharyngeal papillae. Abbreviations: B, buccopharynx; BP, buccopharyngeal papillae; OE, oesophagus; T, teeth; Tb, taste bud; Tf, thyroidal follicle. Staining technique: Haematoxylin-eosin.

Figure 4. General view of a 6 days post hatch larva of white seabream (Diplodus sargus). Abbreviations: AI, anterior (prevalvular) intestine; B, buccopharynx; E, eye; L, liver; OE, oesophagus; PI, posterior (postvalvular) intestine, SB, inflated swimbladder. Staining technique: Haematoxylin-eosin.

Figure 5. Detail of the oesophagus in a 13 days post hatch larva of white seabream (Diplodus sargus). Note the presence of large goblet cells (arrow) in the epithelium lining the oesophageal lumen (asterisk). Abbreviation: L, liver. Staining technique: Haematoxylin-eosin.

Figure 6. General view of the anterior region of the digestive tract in a 30 days post hatch larva of California halibut (Paralichtbys californicus). Abbreviations: B, buccopharynx; H, heart; I, intestine (prevalvular region); L, liver; OE, oesophagus; PN, pronephros. Staining technique: Haematoxylin-eosin.

Figure 7. Detail of the anterior oesophagus in a 21 days post hatch larva of California halibut (Paralichthys californicus) with abundant goblet cells containing a mixture of neutral and carboxylrich glycoconjugates (dark magenta). Staining technique: Alcian Blue pH 2.5 - Periodic acidSchiff (PAS). 
Figure 8. Detail of the oesophagus and liver in a 20 days post hatch larva of Senegal sole (Solea senegalensis). Note the presence of PAS-positive goblet cells (arrow) in the anterior region of the oesophagus and the absence of them in the posterior oesophagus (asterisk). PAS-positive glycogen deposits are observed in the liver (dark magenta, arrowhead). Staining technique: Periodic acid-Schiff (PAS).

Figure 9. Gastric glands (GG) in differentiation in a 24 days post hatch California halibut larva. Abbreviations: AI, anterior (prevalvular) intestine; OE, oesophagus. Staining technique: Haematoxylin-eosin.

Figure 10. Detail of the anterior and ventral region of the digestive system in a metamorphosing larva (42 days post hatch) of California halibut (Paralichthys californicus) fed on Artemia cysts (asterisk). Note the completely developed stomach with gastric glands and the large development of the liver with glycogen deposits (PAS positive) and the. Abbreviations: AI, anterior (prevalvular) intestine; CS, cardiac stomach (glandular region); L, liver; OE, oesophagus; PS, pyloric stomach (non-glandular region); PV, pyloric valve; S, stomach. Staining technique: Alcian Blue pH 2.5 - Periodic acid-Schiff (PAS).

Figure 11. Detail of gastric glands in an early juvenile (70 days post hatch) of white seabream (Diplodus sargus). Staining technique: Haematoxylin-eosin.

Figure 12. Stomach in a 42 days post hatch larvae of California halibut (Paralichthys californicus). Gastric secretory cells have a PAS-positive apical border, and their secretory products are rich in neutral mucosubstances (magenta, PAS positive). Staining technique: Alcian Blue pH 1.0 Periodic acid-Schiff (PAS).

Figure 13. Digestive system in a 19 days post hatch larvae of California halibut (Paralichthys californicus) fed Artemia nauplii (asterisk). AI, anterior (prevalvular) intestine; EdP, endocrine pancreas (islet of Langerhans); ExP, exocrine pancreas; L, liver; PI, posterior (postvalvular) intestine; PN, pronefros. Staining technique: Haematoxylin-eosin. 
Figure 14. Differentiation of the liver and pancreas in a 2 days post hatch larva of California halibut (Paralichthys californicus). Abbreviations: L, liver; OE, oesophagus; P, pancreas; YS, yolk sac. Staining technique: Haematoxylin-eosin.

Figure 15. Detail of the accessory digestive glands in a 20 days post hatch larva of Senegal sole (Solea senegalensis). Note the pancreas containing protein rich granules (Bromophenol blue positive) and hepatic proteins distributed mainly along sinusoids. Staining technique: Bromophenol Blue.

Figure 16. General view of a 15 days post hatch larva of gilthead seabream (Sparus aurata). Note the presence of proteic cytoplasmatic inclusions in the enterocytes of the prevalvular intestine showing great affinity for the Orange $G$, and the exocrine pancreas containing protein rich granules (enzymatic precursors). Abbreviations: AI, anterior (prevalvular) intestine; B, buccopharynx; ExP, exocrine pancreas; L, liver; PN, pronephros; OC; otic capsule; PI, posterior (postvalvular) intestine; Ud; urinary duct. Staining technique: VOF (light green-orange G-acid fuchsin).

Figure 17. Cross-section (x1200) of gilthead seabream larvae: (A) a prelarva several hours after hatching, where the pancreas primordium (PP) can be seen as a dorsal thickening of the gut $(\mathrm{G})$; (B) a 2 day-old prelarva, where the exocrine pancreas (ExP) contains a clearly individualised endocrine islet (EnP). (from Guyot et al. 1998)

Figure 18. General view of a 3 days post hatch first feeding larva of California halibut (Paralichthys californicus). Abbreviations: AI, anterior (prevalvular) intestine; Gb, gallbladder; L, liver; P, pancreas; YS, yolk sac.. Staining technique: Haematoxylin-eosin.

Figure 19. Detail of the endocrine pancreas (islet of Langerhans, asterisk) surrounded by exocrine tissue in a 25 days post hatch California halibut (Paralichthys californicus) larva. Staining technique: Haematoxylin-eosin.

Figure 20. Amylase specific activity during the development of barramundi and European sea bass larvae (from Zambonino Infante and Cahu, 1994 and Ma et al., 2001). 
Figure 21. Expression of amylase during the development of barramundi larvae, Lates calcarifer (from Ma et al., 2001).

Figure 22. Expression of trypsin in 25-day-old and 42-day-old European sea bass larvae fed diets incorporating different level of native protein (fish meal) (from Cahu et al., 2004).

Figure 23. Expression of lipase (A) and phospholipase A2 (B) in 40-day-old European sea bass larvae fed diets incorporating different levels of triglycerides and phospholipids, respectively (from Cahu et al., 2003).

Figure 24. Detail of the liver of an Artemia-feeding larva (35 days post-hatch, dph) of California halibut (Paralichthys californicus), note the large accumulation of lipids inside the hepatocytes. Inner picture: Liver of a rotifer-feeding larva (15 dph) deprived of lipid inclusions. Staining technique: Haematoxylin-eosin.

Figure 25. Postvalvular intestine (PI) with large accumulation of eosinophilic supranuclear bodies in the epithelium in a 3 days post hatch first feeding larvae of California halibut (Paralicbthys californicus). Abbreviations: AI; anterior (prevalvular) intestine; IV, intestinal valve. Staining technique: Haematoxylin-eosin.

Figure 26. Detail of intestinal goblet cells (arrow) of the posterior intestine in a 13 days post hatch larvae of California halibut (Paralichthys californicus). Note the PAS-positive microvilli (arrowhead) covering the epithelial surface and goblet cells (arrow) containing a mixture of carboxyl-rich glycoconjuages and neutral mucosubstances (magenta). Staining technique: Alcian Blue pH2.5 - Periodic acid-Schiff (PAS).

Figure 27. General view of the digestive system in a metamorphosing larva (42 days post hatch) of California halibut (Paralichthys californicus) fed on Artemia nauplii (asterisk). Abbreviations: A, anus; AI, anterior (prevalvular) intestine; B, buccopharynx; L, liver; M, metanephros; OE; oesophagus; P, pancreas (endocrine and exocrine parts); PI, posterior (postvalvular) intestine; R, rectum; Ud; urinary duct. Staining technique: Alcian Blue pH 2.5 - Periodic acid-Schiff (PAS).

Figure 28. Postvalvular intestine (PI) with large accumulation of eosinophilic supranuclear bodies in the epithelium in a 3 days post hatch first feeding larvae of California halibut (Paralichthys 
californicus). Abbreviations: AI; anterior (prevalvular) intestine; IV, intestinal valve. Staining technique: Haematoxylin-eosin.

Figure 29. Detail of the columnar epithelium lining the anterior (AI) and posterior (PI) intestine in a 24 days post hatch larvae of California halibut (Paralichthys californicus). Note the PAS-positive supranuclear bodies in the enterocytes of the postvalvular intestine. Staining technique: Alcian Blue pH2.5 - Periodic acid-Schiff (PAS).

Figure 30. Detail of epithelial folds of the postvalvular (posterior) intestine in a 25 days post hatch larvae of California halibut (Paralichthys californicus). Note the PAS-positive microvilli (arrowhead) covering the epithelial surface and goblet cells (arrow) containing neutral mucosubstances. Staining technique: Periodic acid-Schiff (PAS).

Figure 31. General view of a 19 days post hatch larva of California halibut (Paralichthys californicus). Abbreviations: AI, anterior (prevalvular) intestine; B, buccopharyngeal opening; E, eye; EnP, endocrine pancreas (Islet of Langerhans); ExP, exocrine pancreas; L, liver; M, metanephros; OC; otic capsule; PI, posterior (postvalvular) intestine; R, rectum; Ud; urinary duct. Staining technique: Haematoxylin-eosin.

Figure 32. Detail of pyloric caeca in an early juvenile (70 days post hatch) of white seabream (Diplodus sargus). Staining technique: Haematoxylin-eosin.

Figure 33. Maturation of enterocytes: changes in the activity of cytosolic peptidase (leucinealanine peptidase) and brush border membrane enzyme (alkaline phosphatase) during the development of sea bass larvae. 

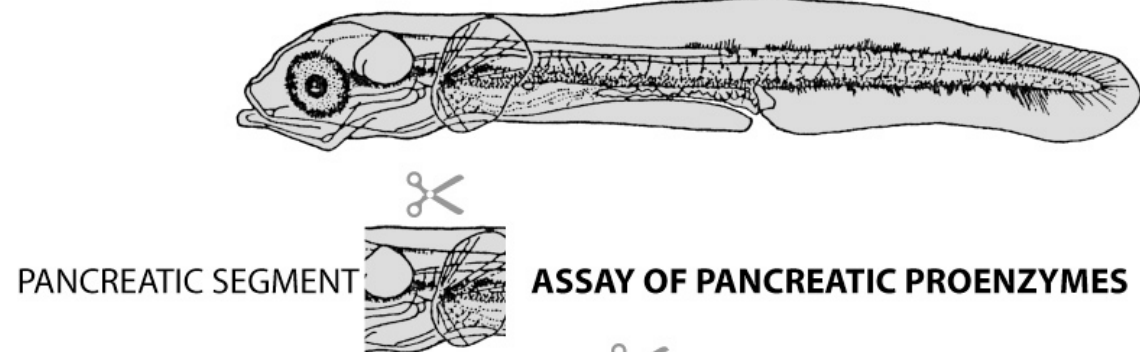

ASSAY OF PANCREATIC PROENZYMES

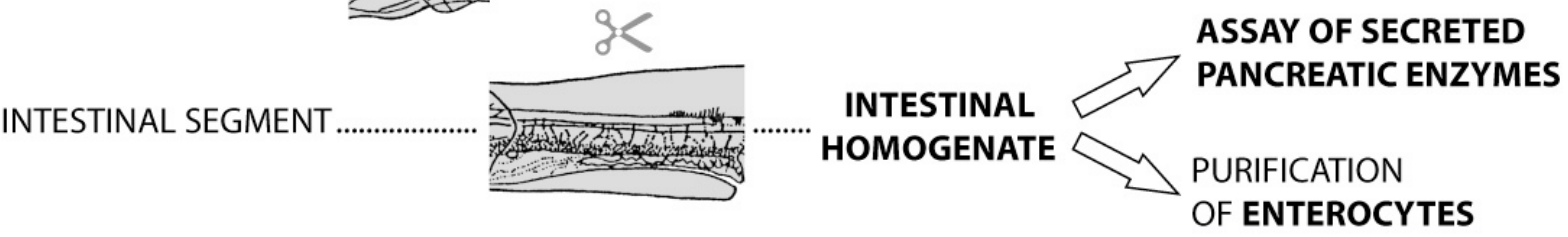

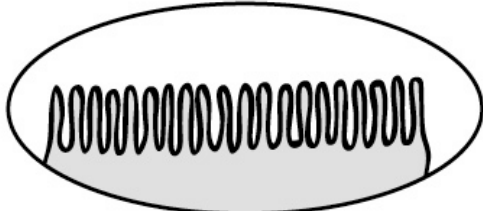

BRUSH BORDER PURIFICATION

ASSAY OF BBM ENZYMES

Enzymes linked to cell membrane

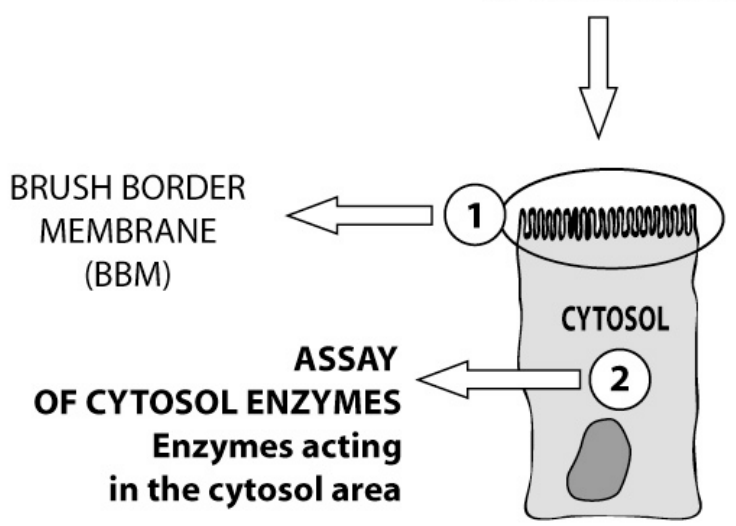

Figure 1 


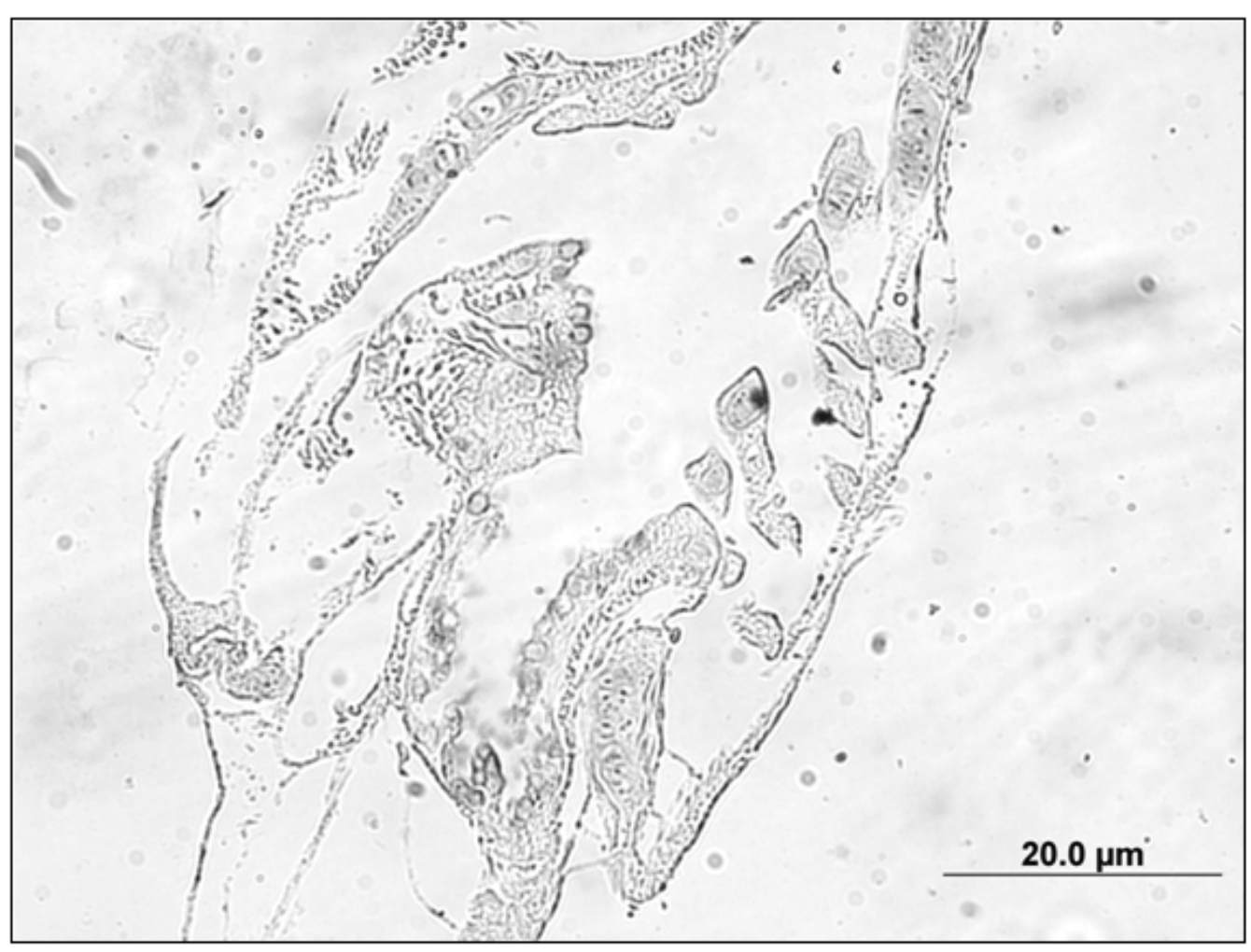

Figure 2 


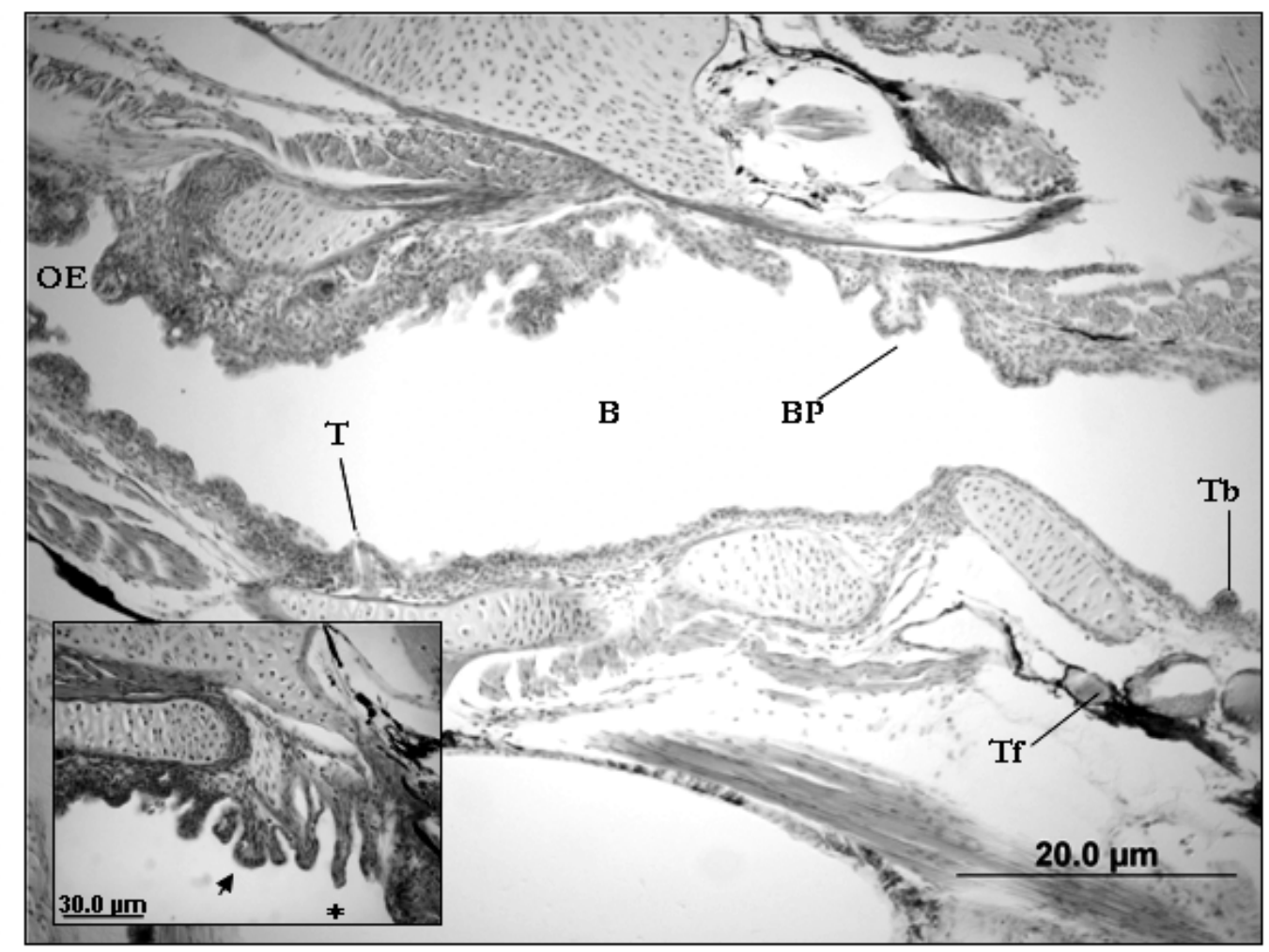

Figure 3 


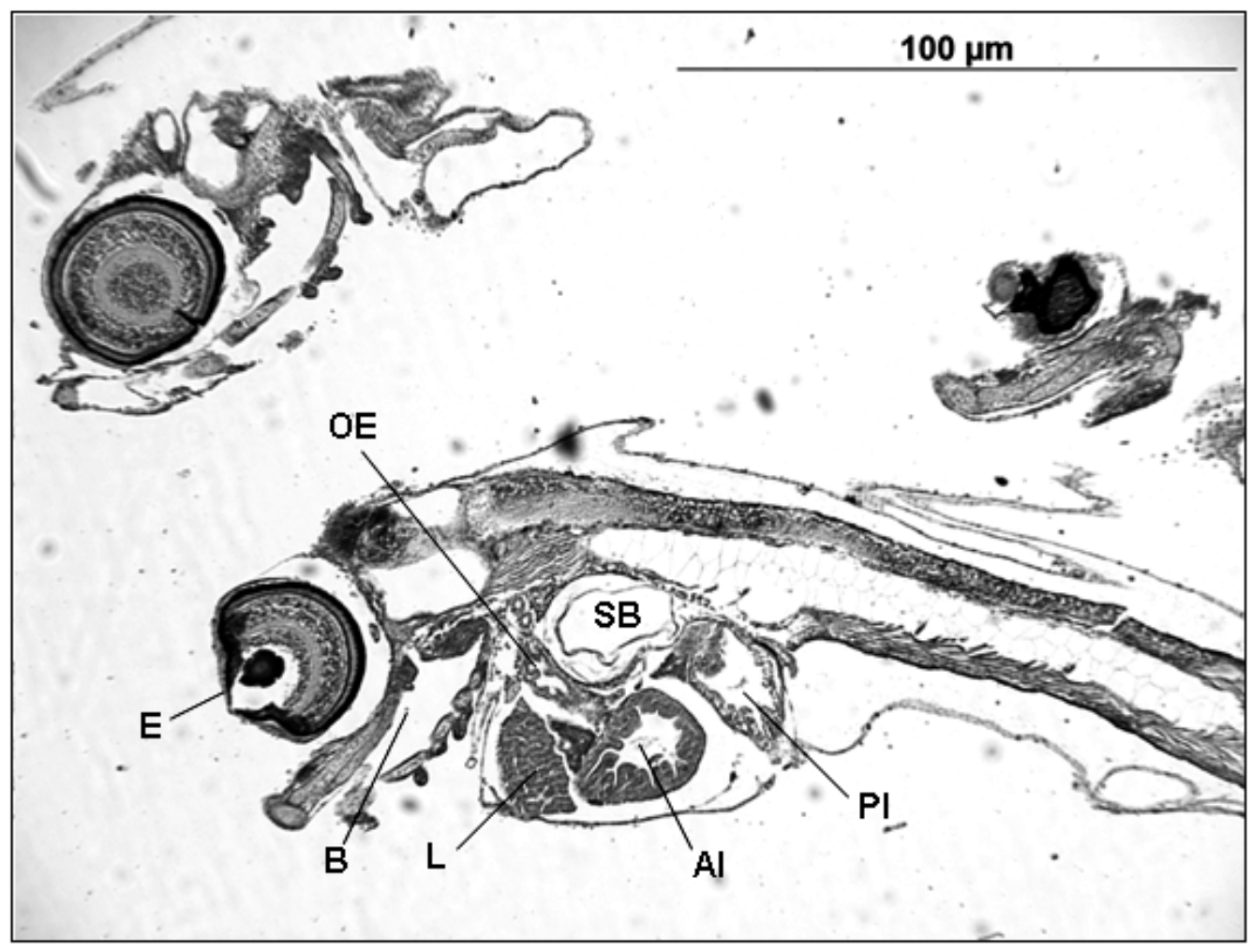

Figure 4 


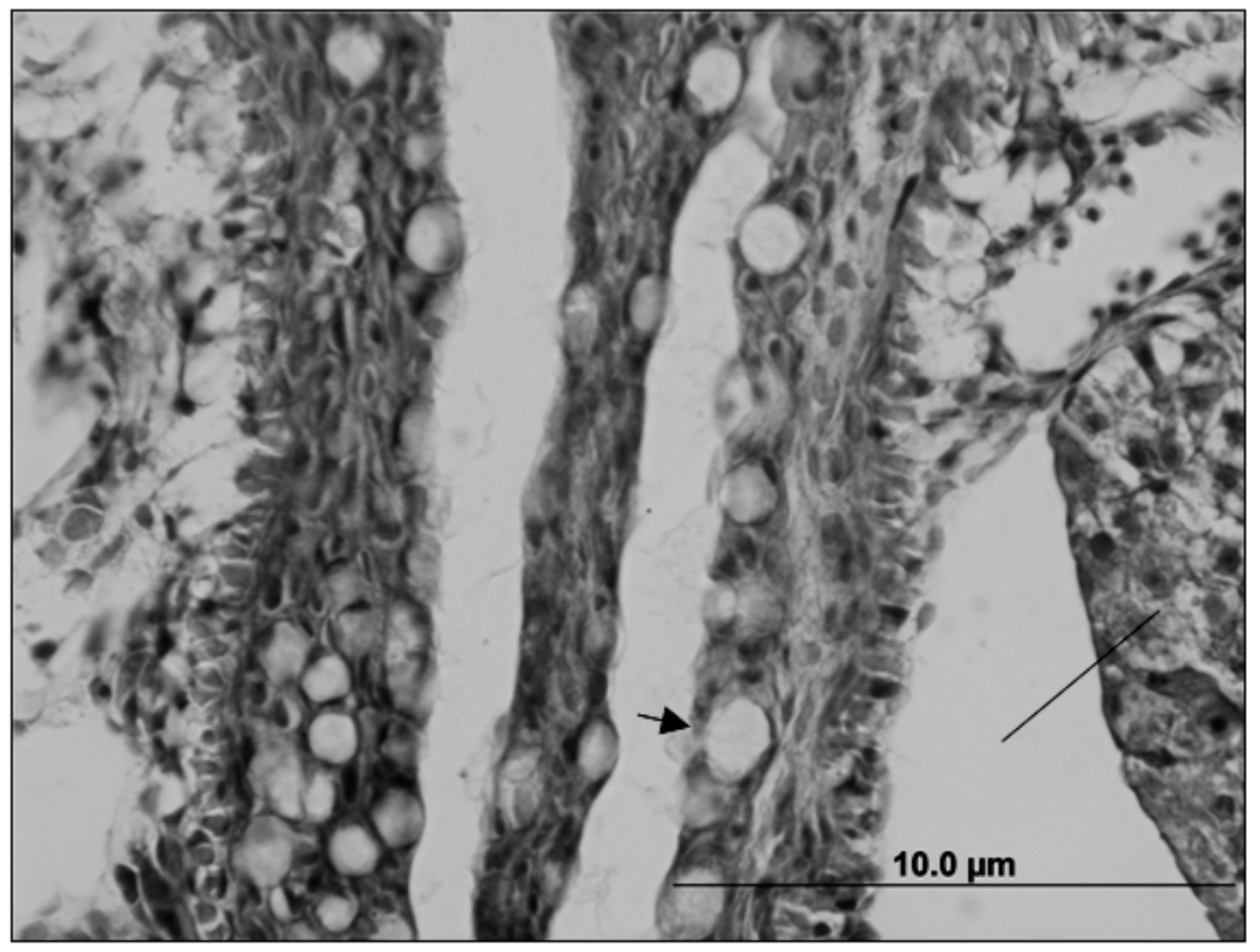

Figure 5 


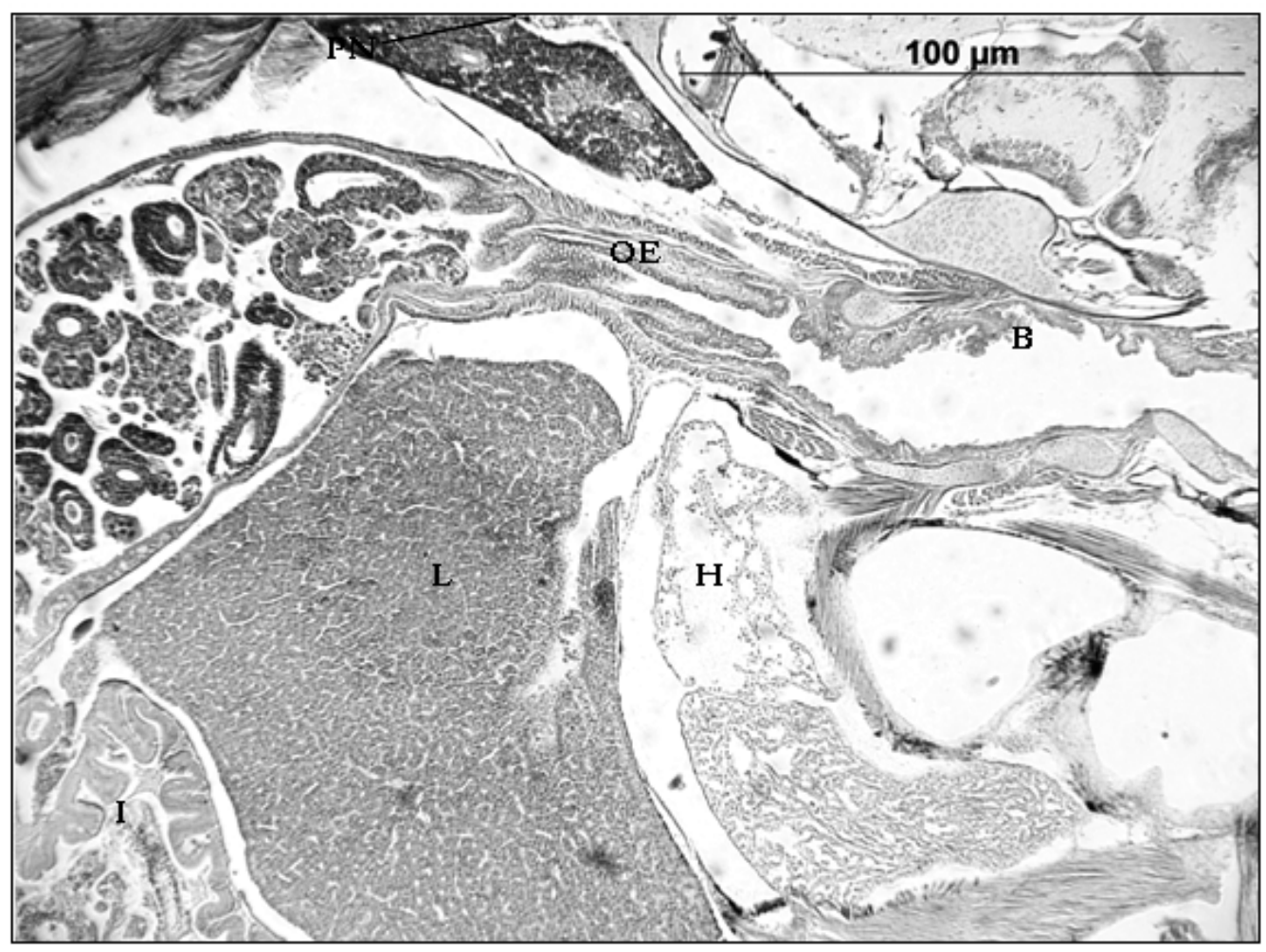

Figure 6 


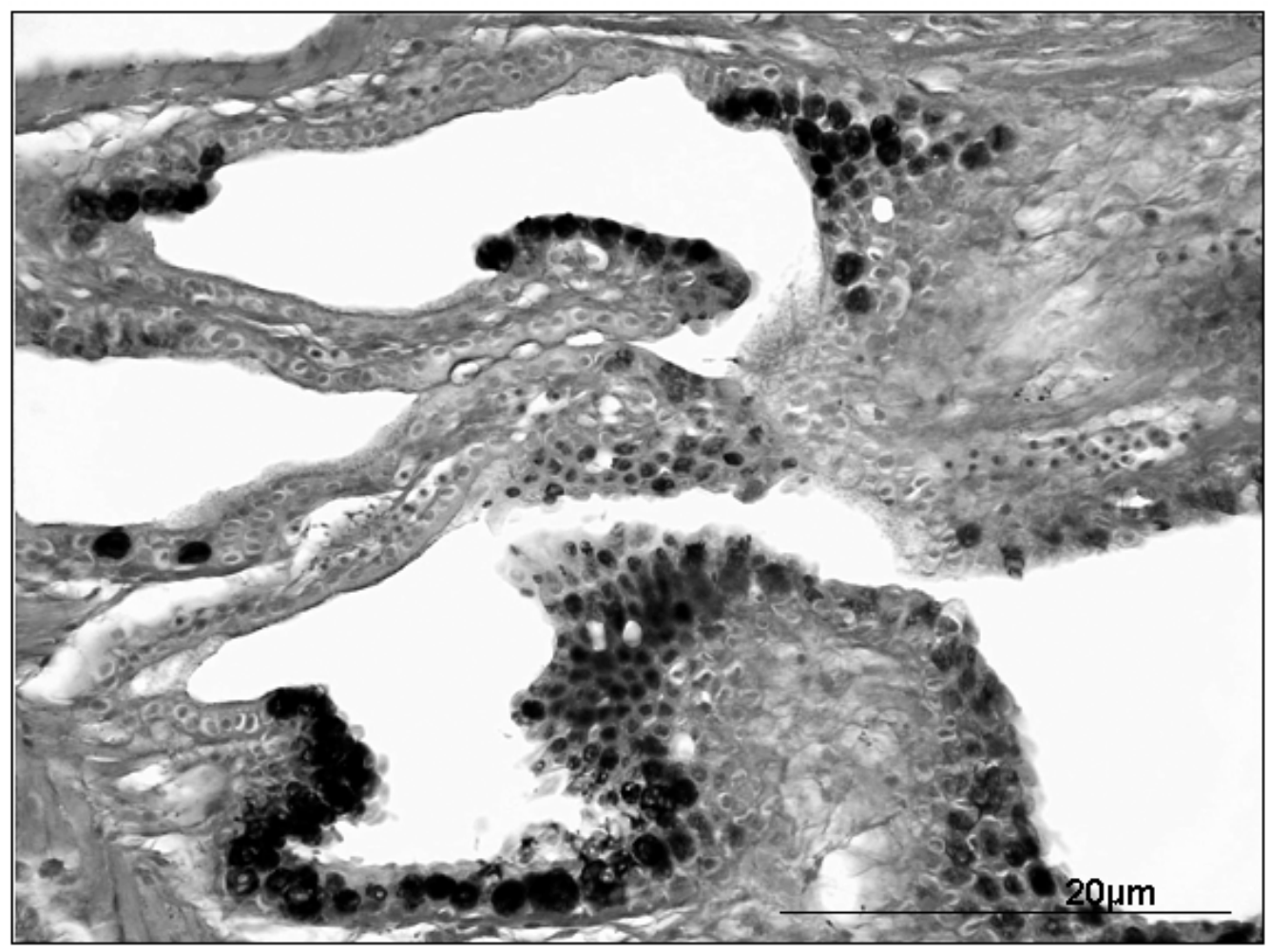

Figure 7 


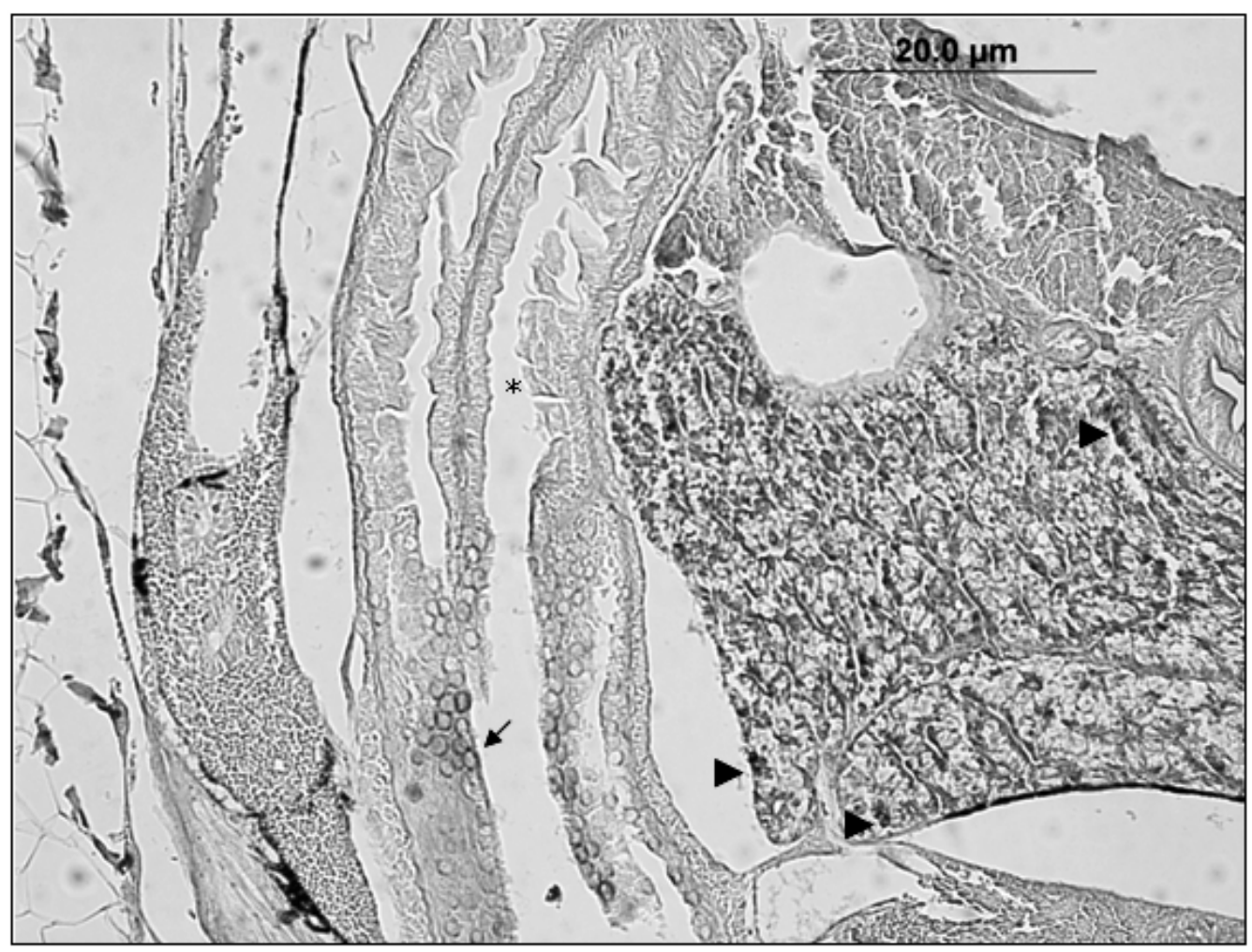

Figure 8 


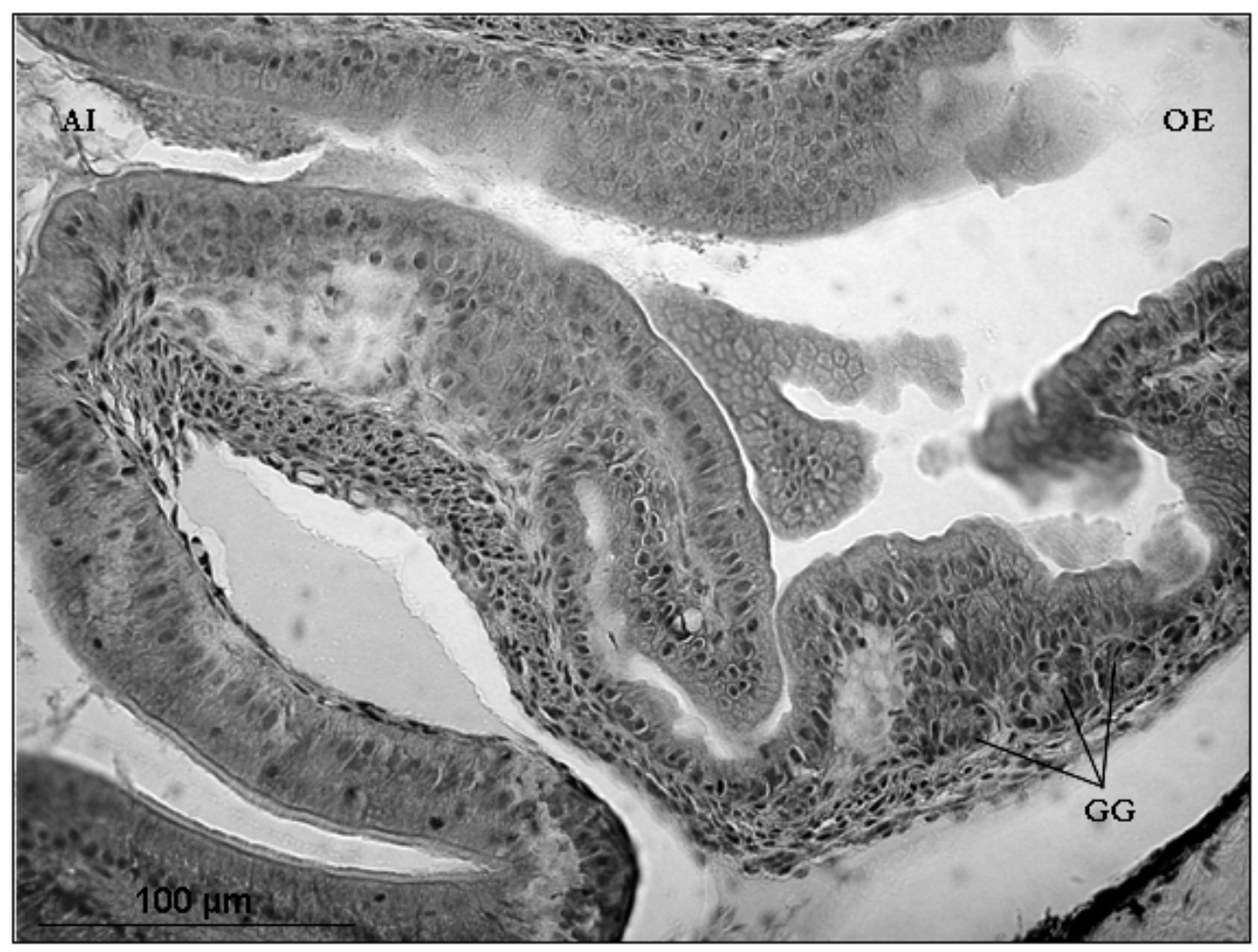

Figure 9 


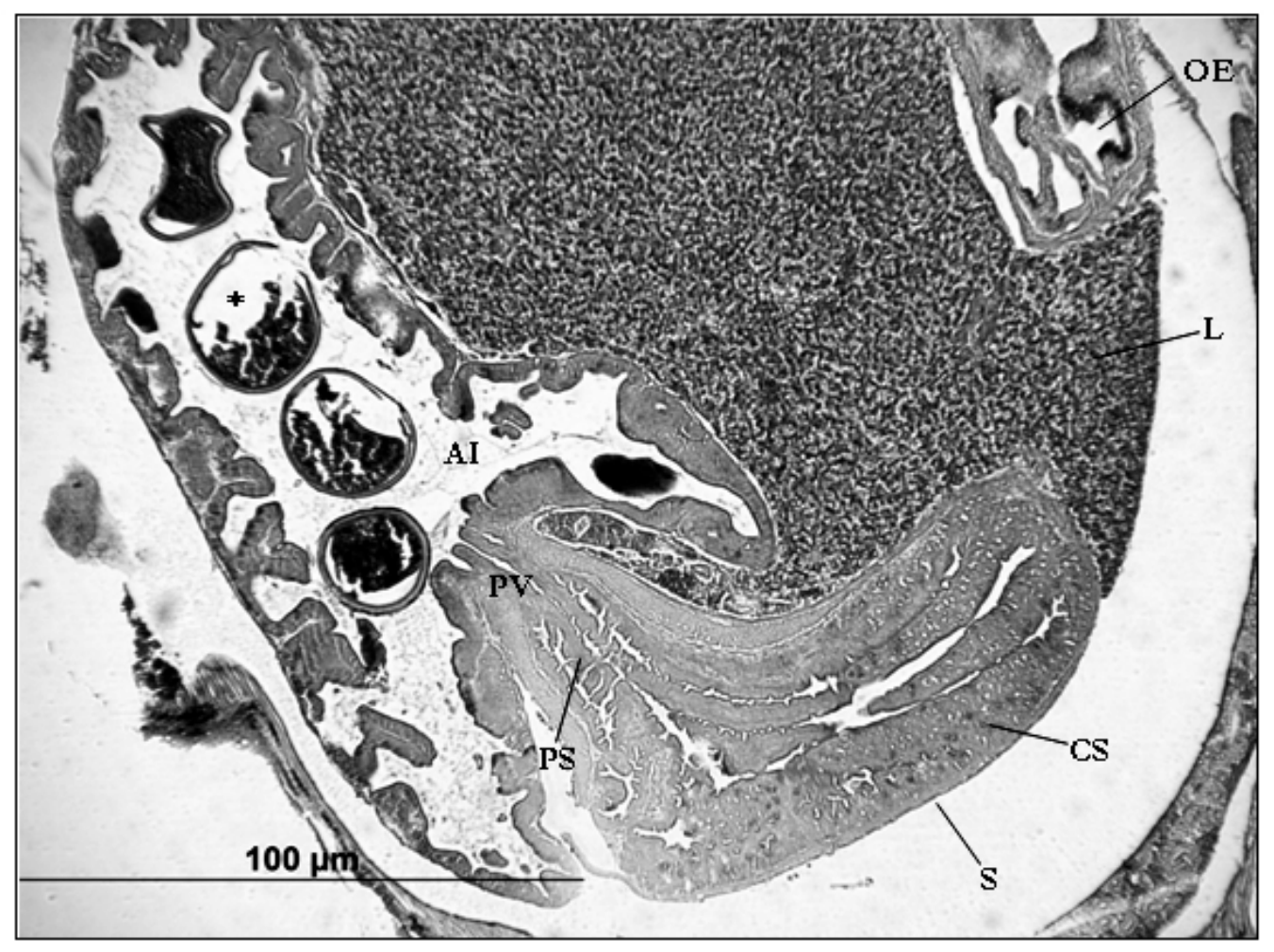

Figure 10 


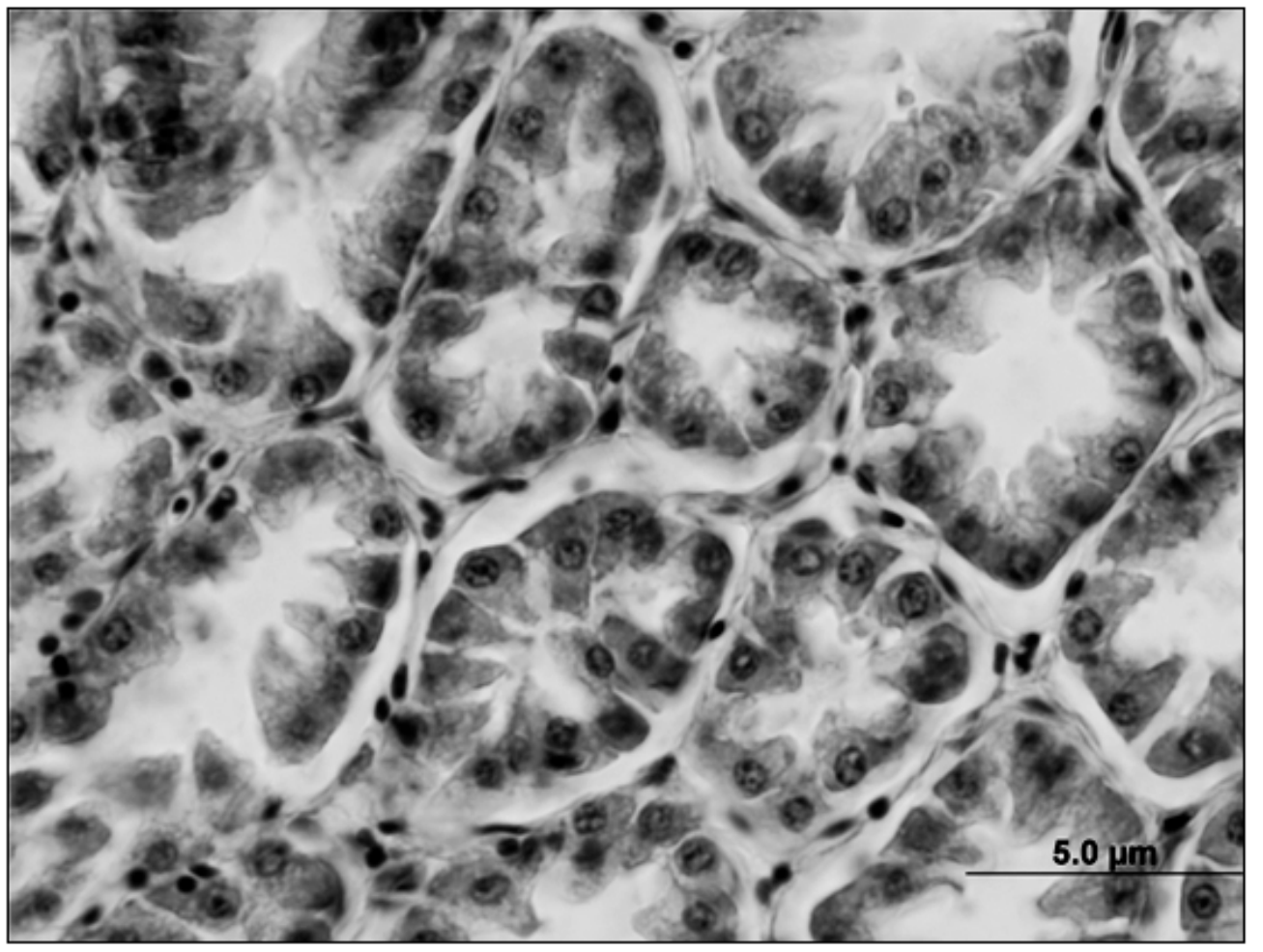

Figure 11 


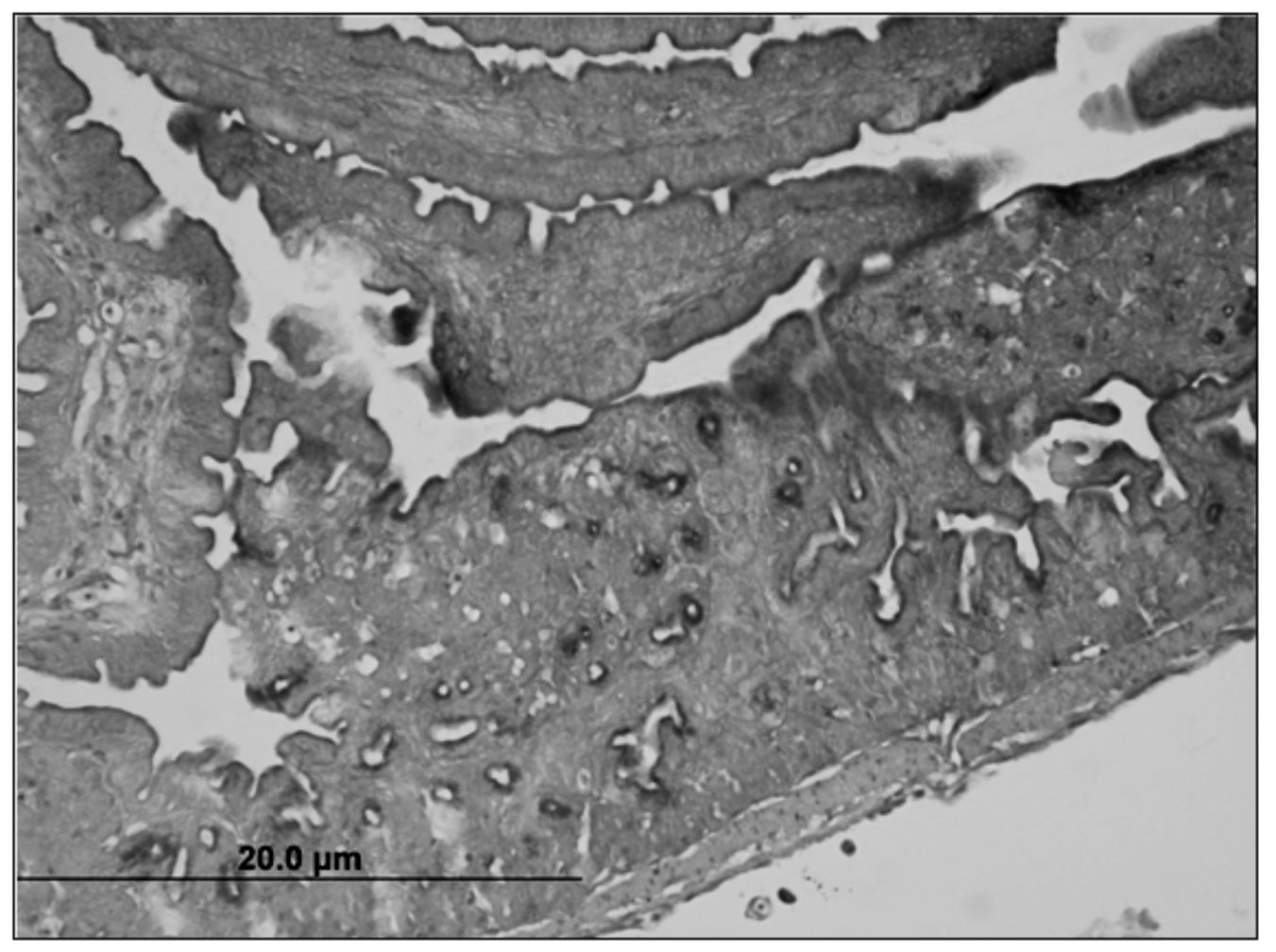

Figure 12 


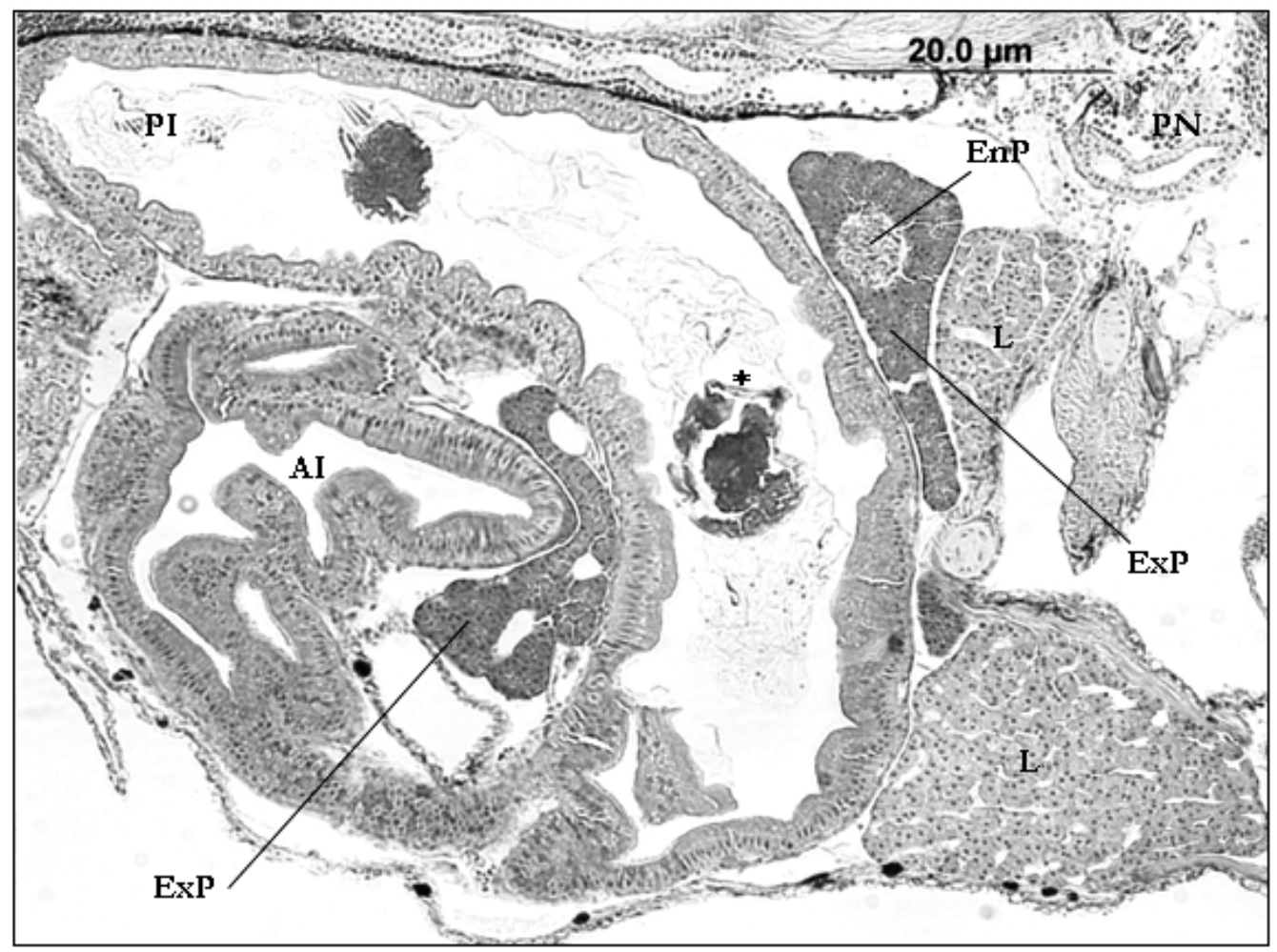

Figure 13 


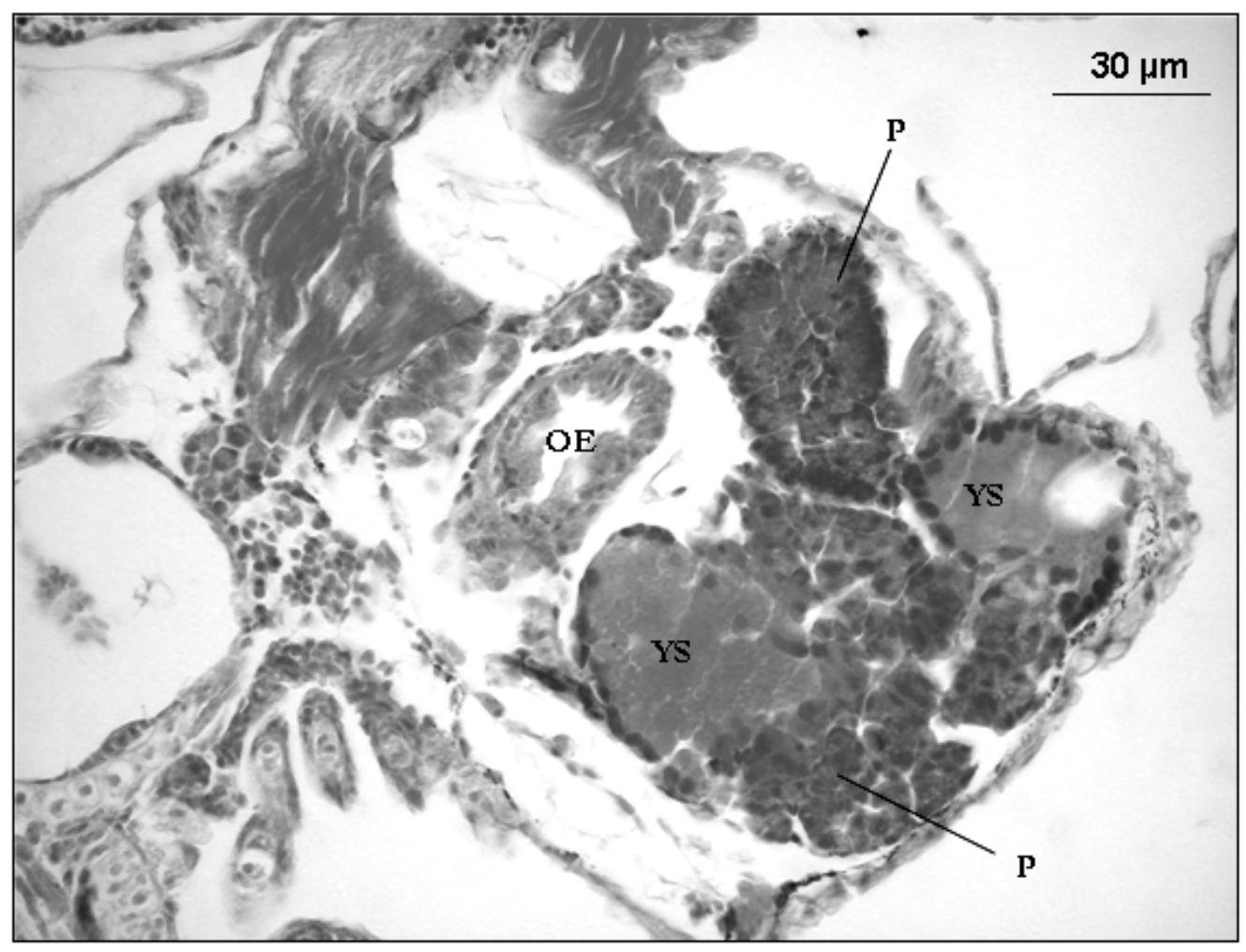

Figure 14 


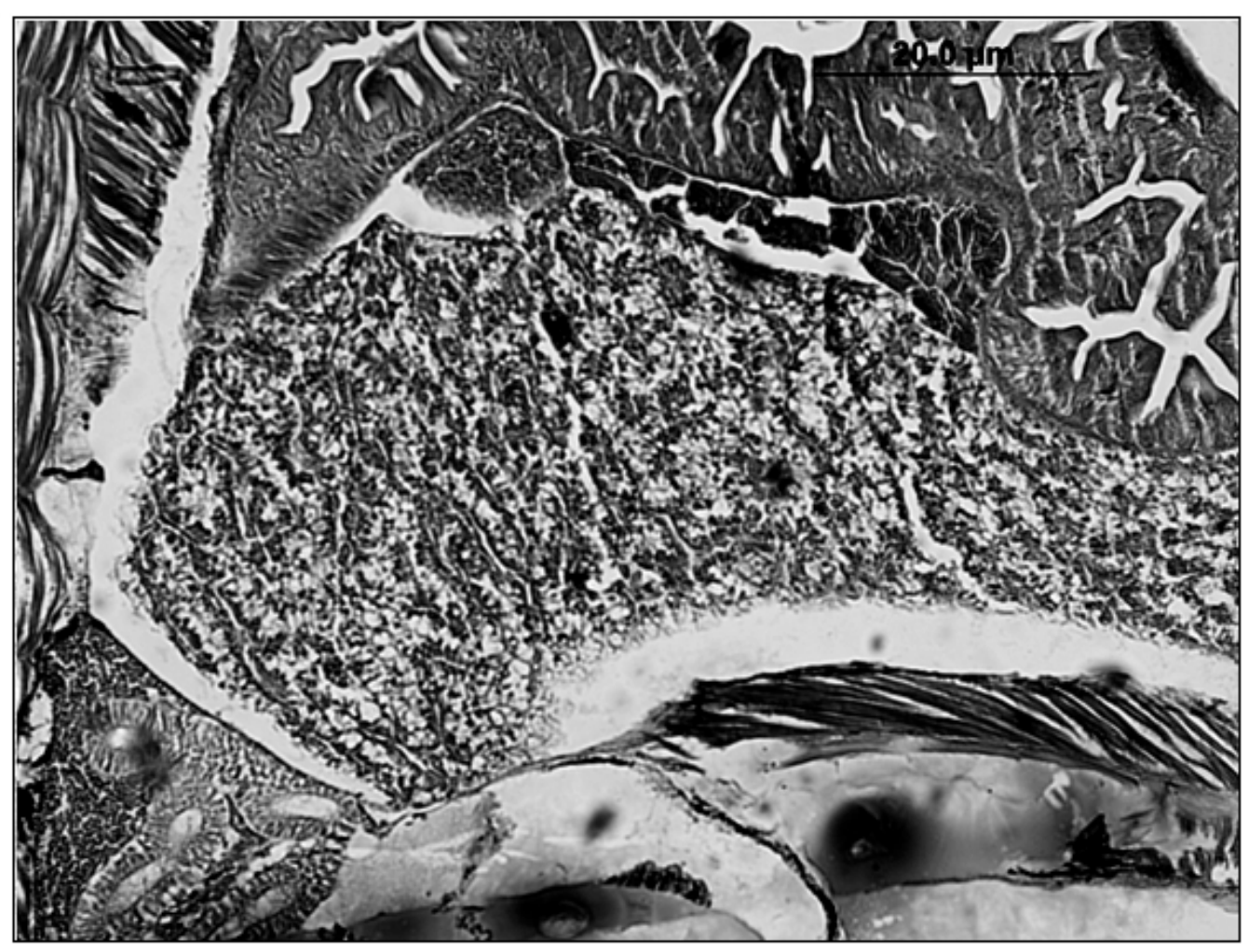

Figure 15 


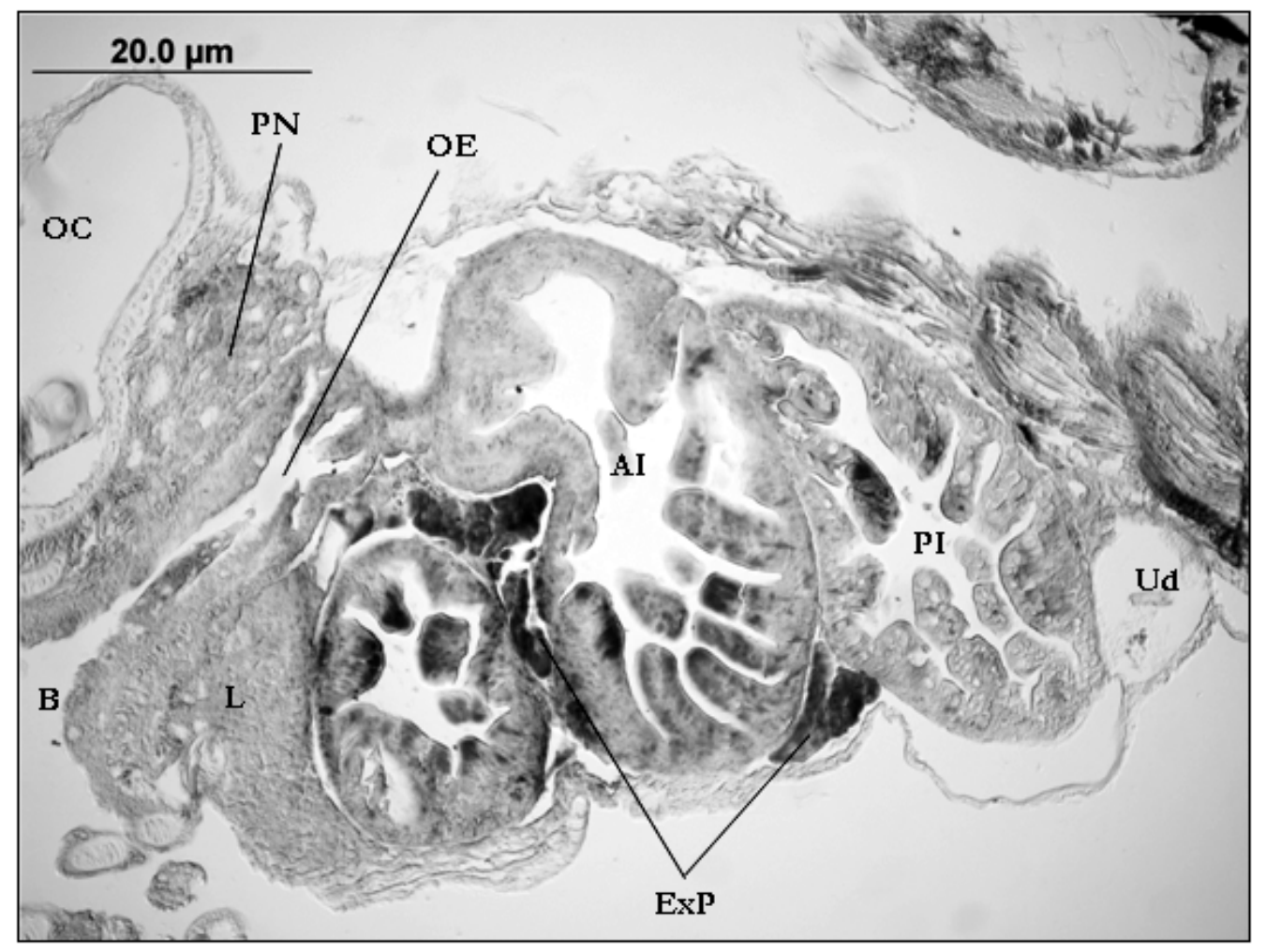

Figure 16 

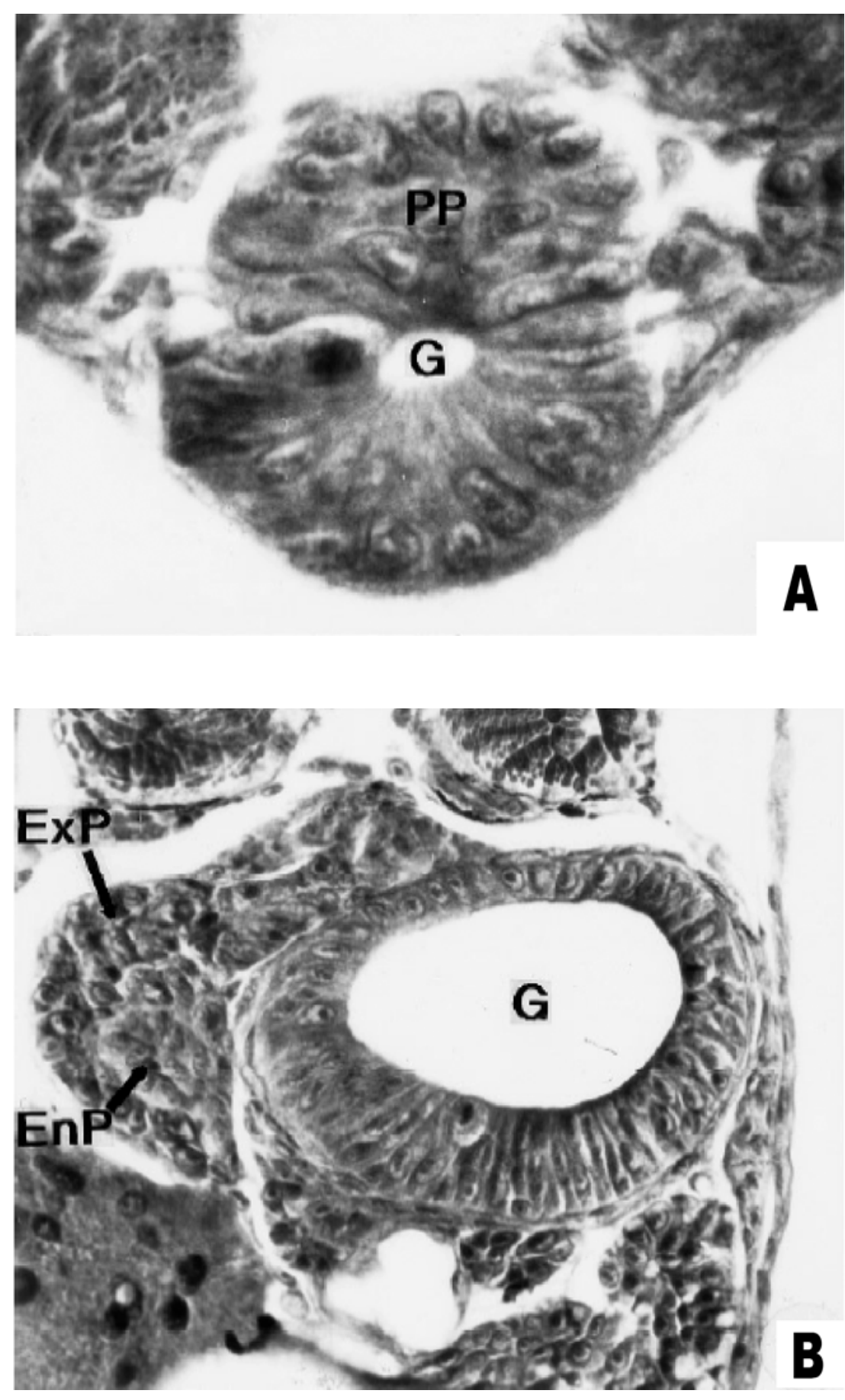

Figure 17 


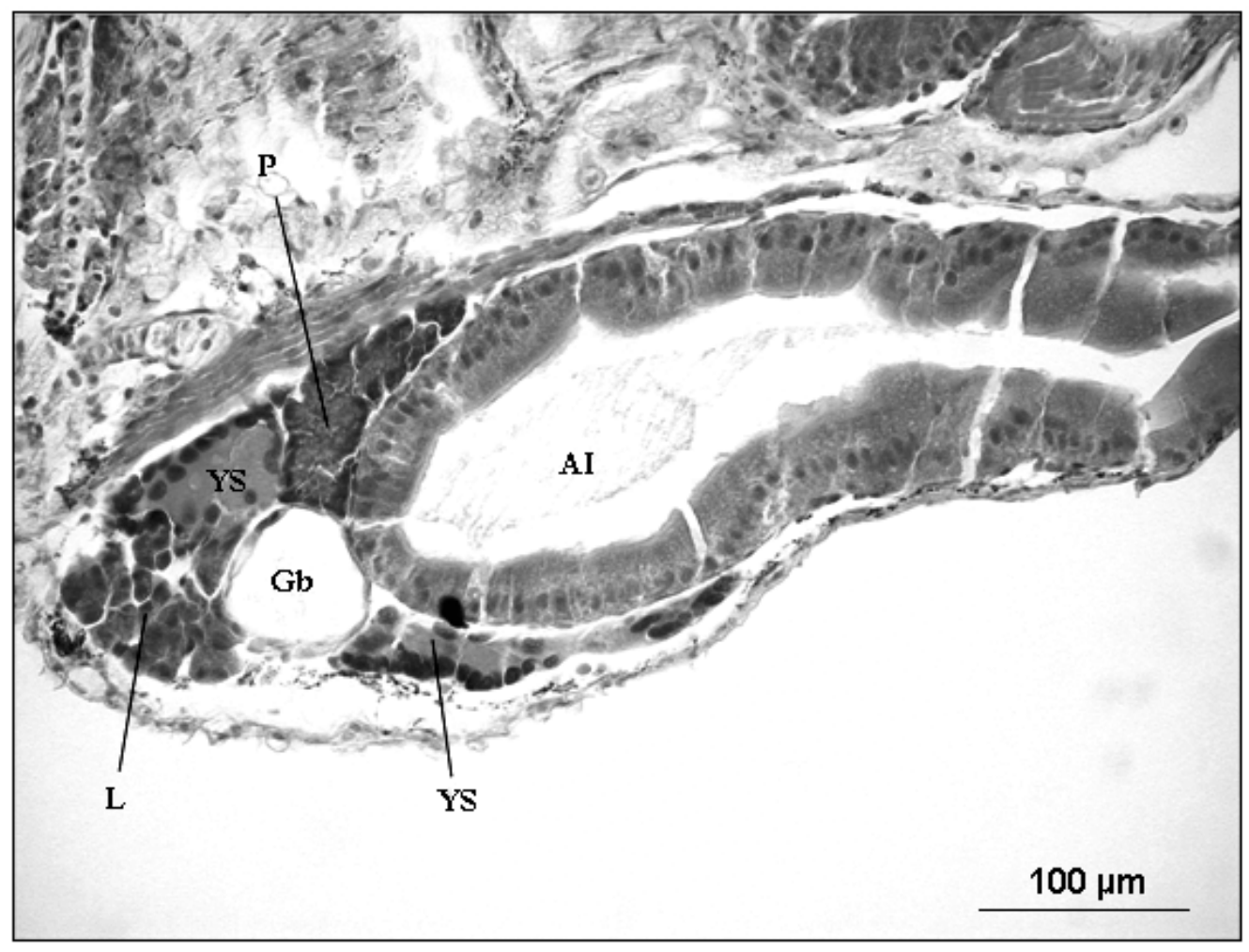

Figure 18 


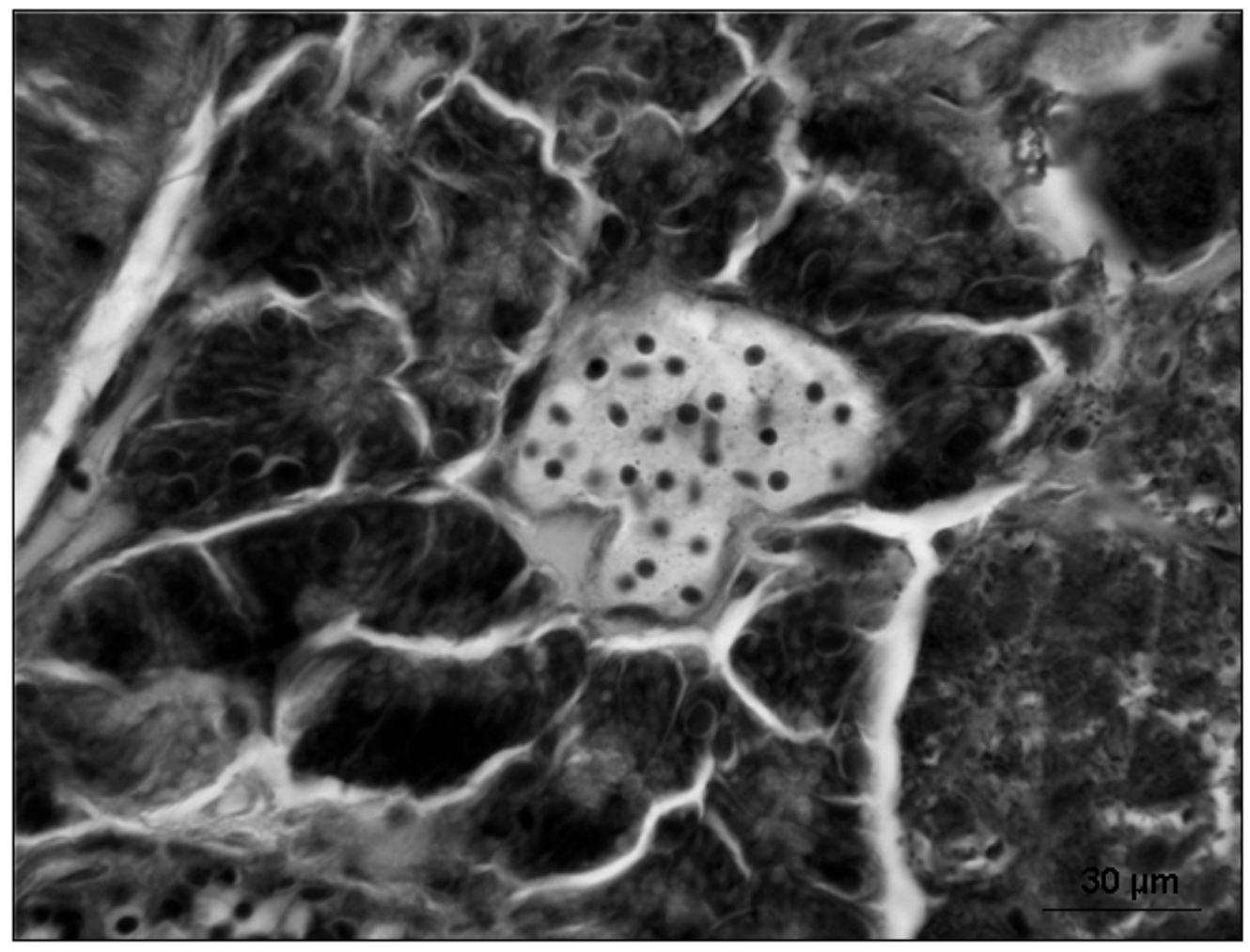

Figure 19 


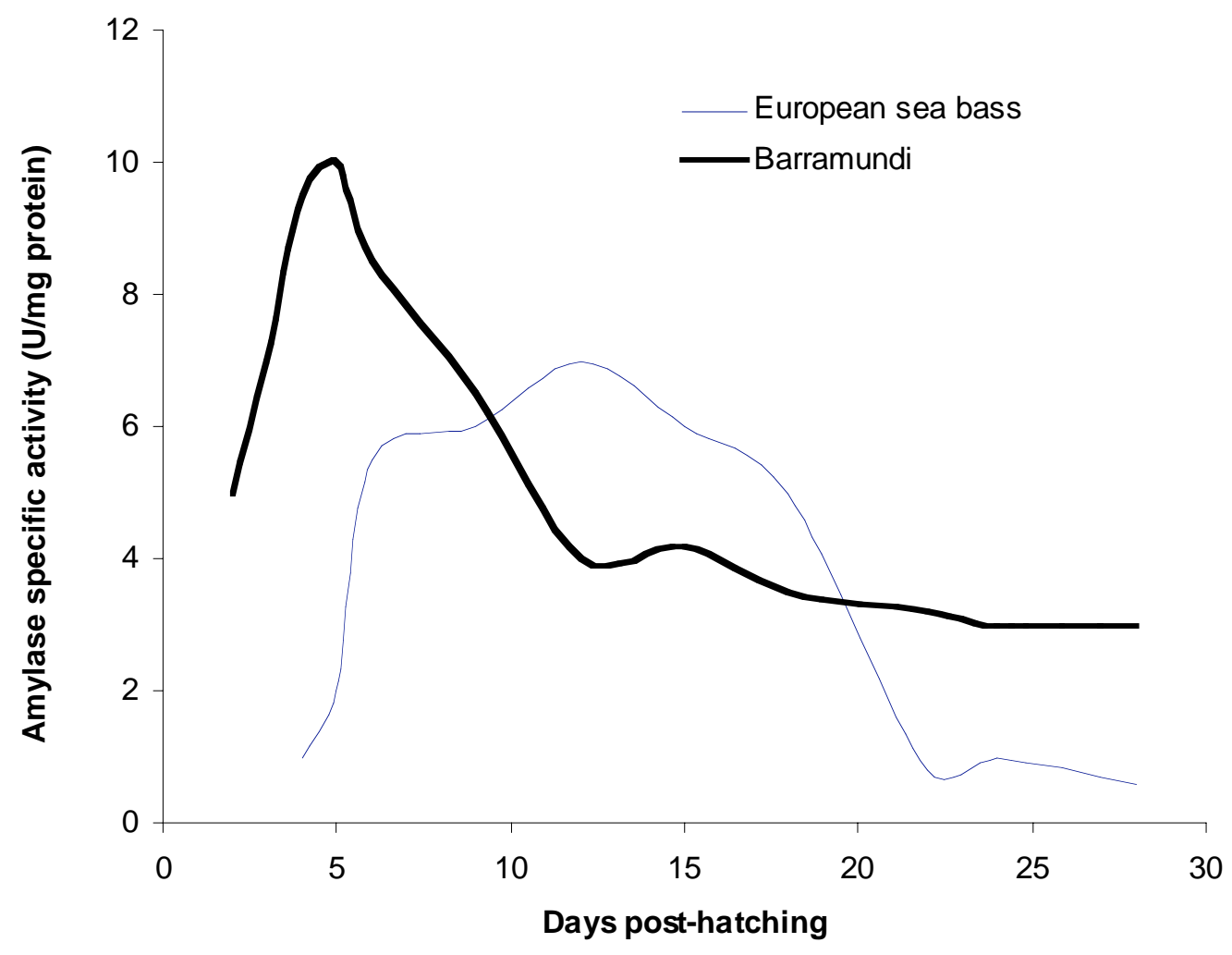

Figure 20 


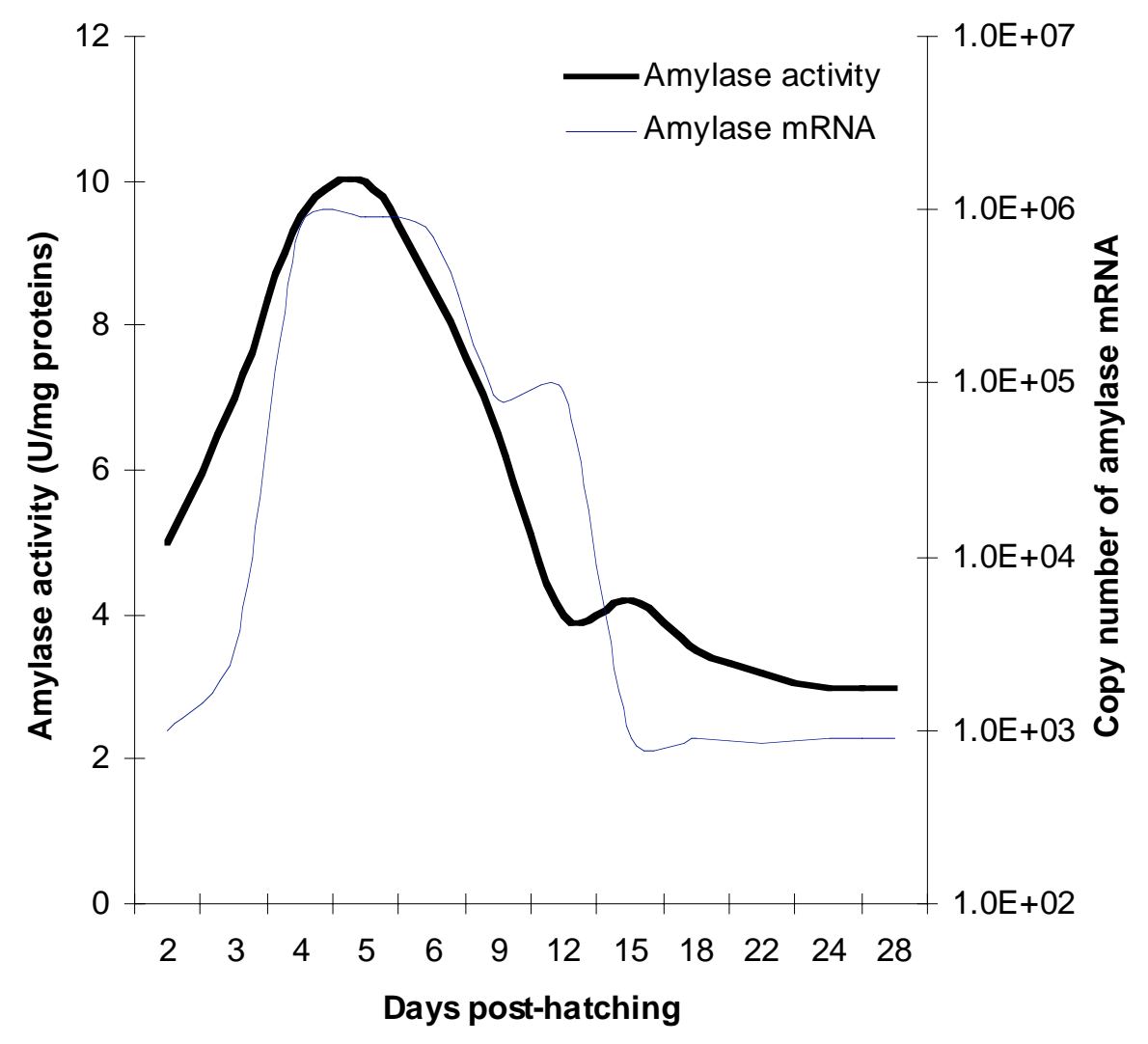

Figure 21 


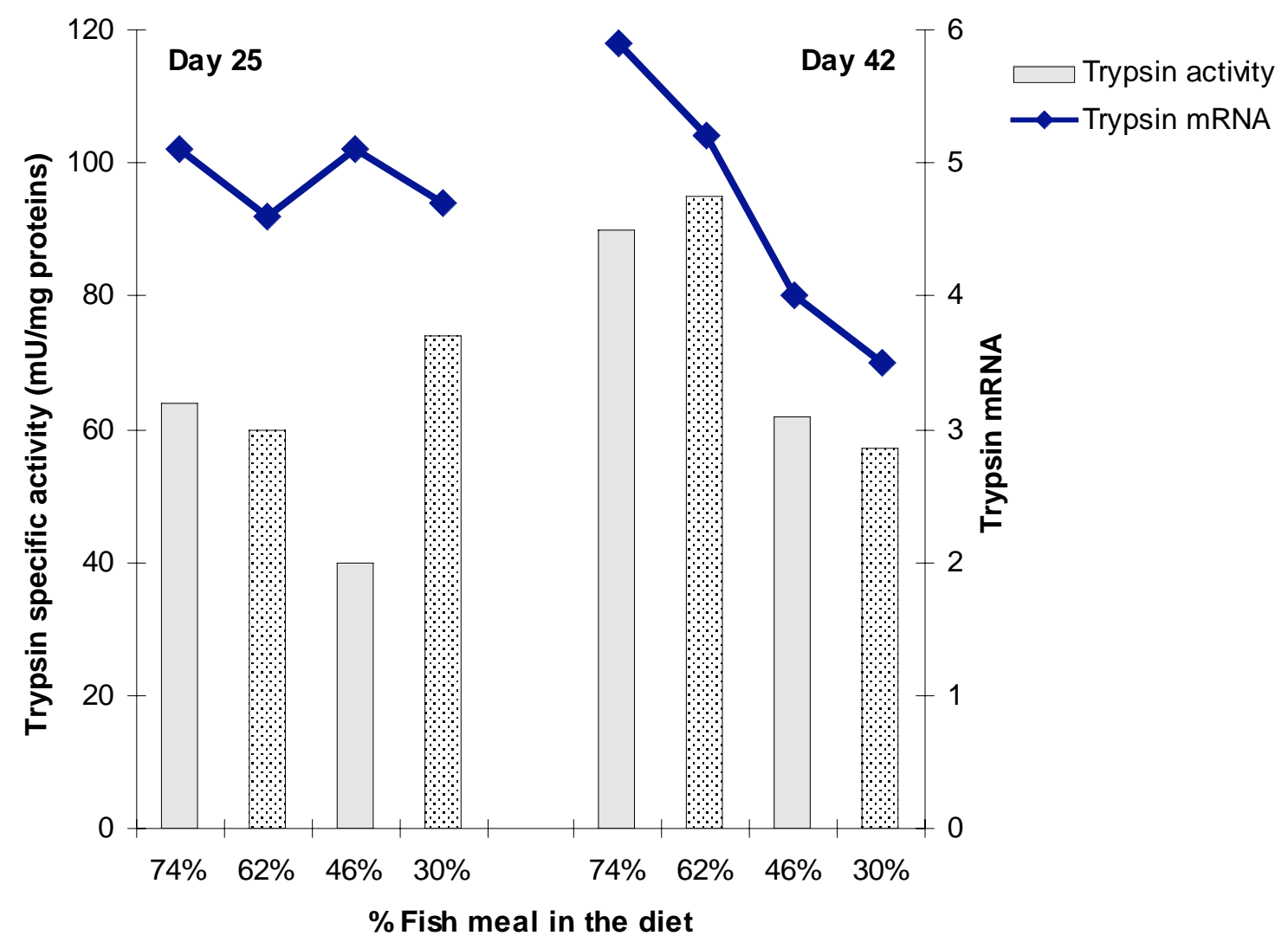

Figure 22 

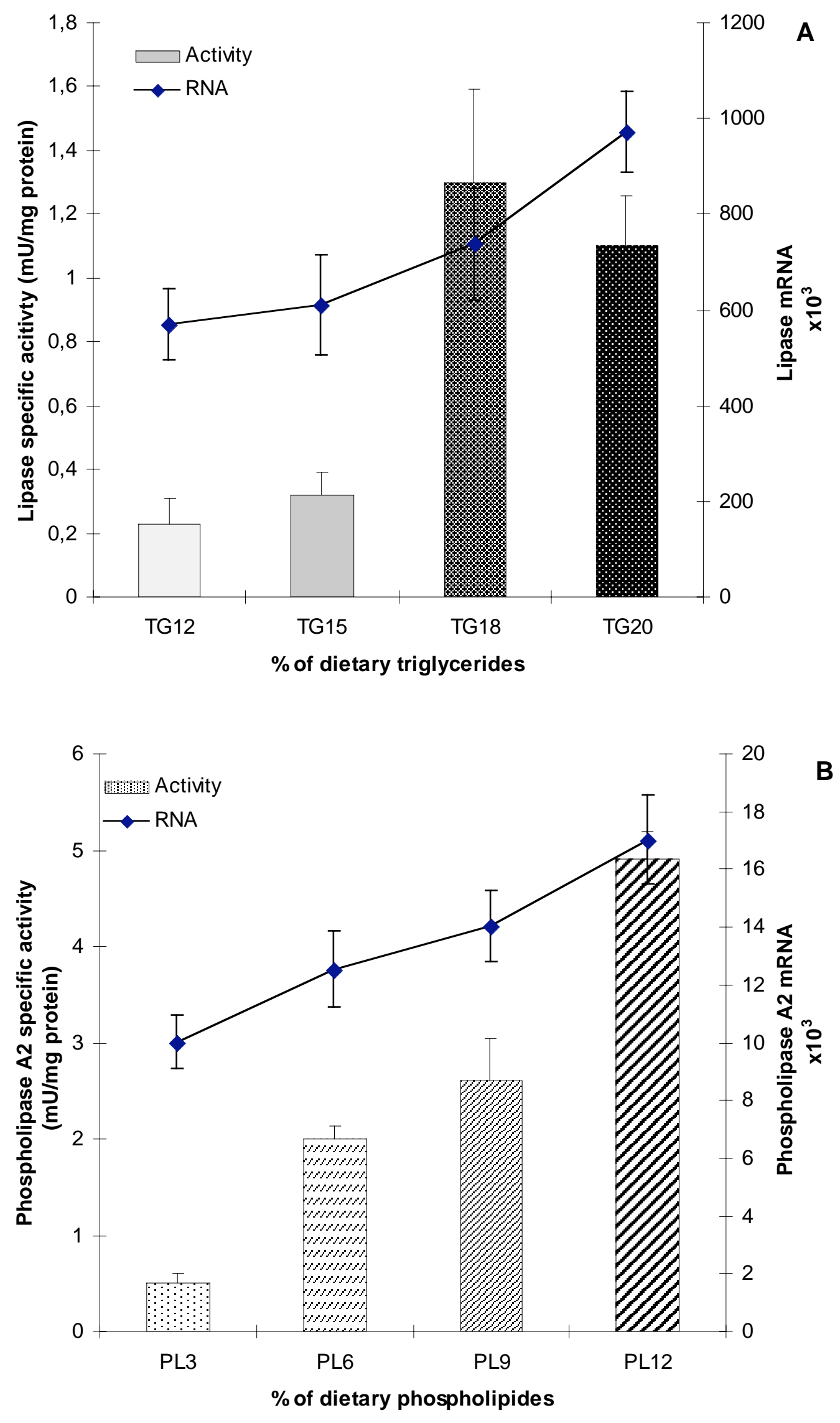

Figure 23 


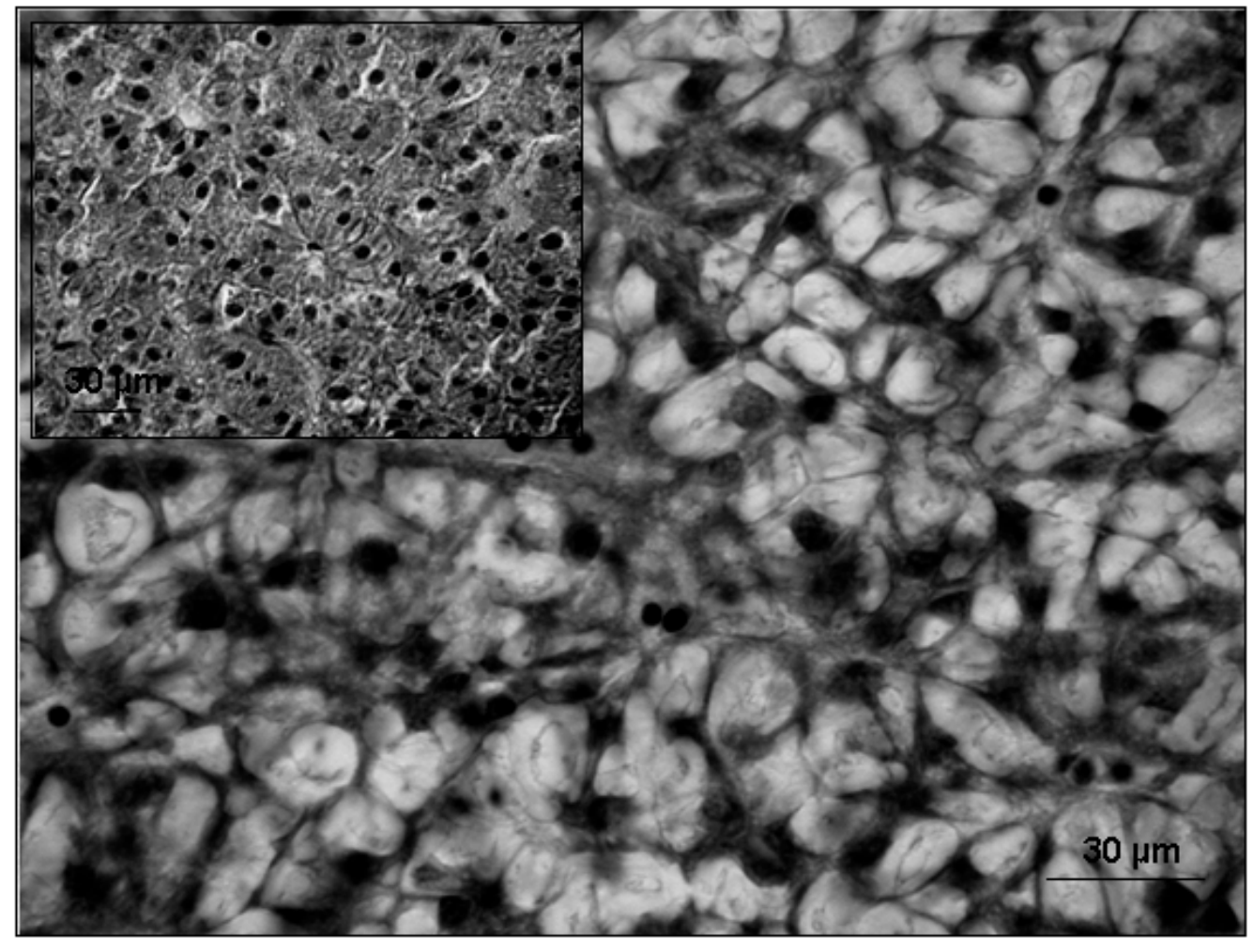

Figure 24 


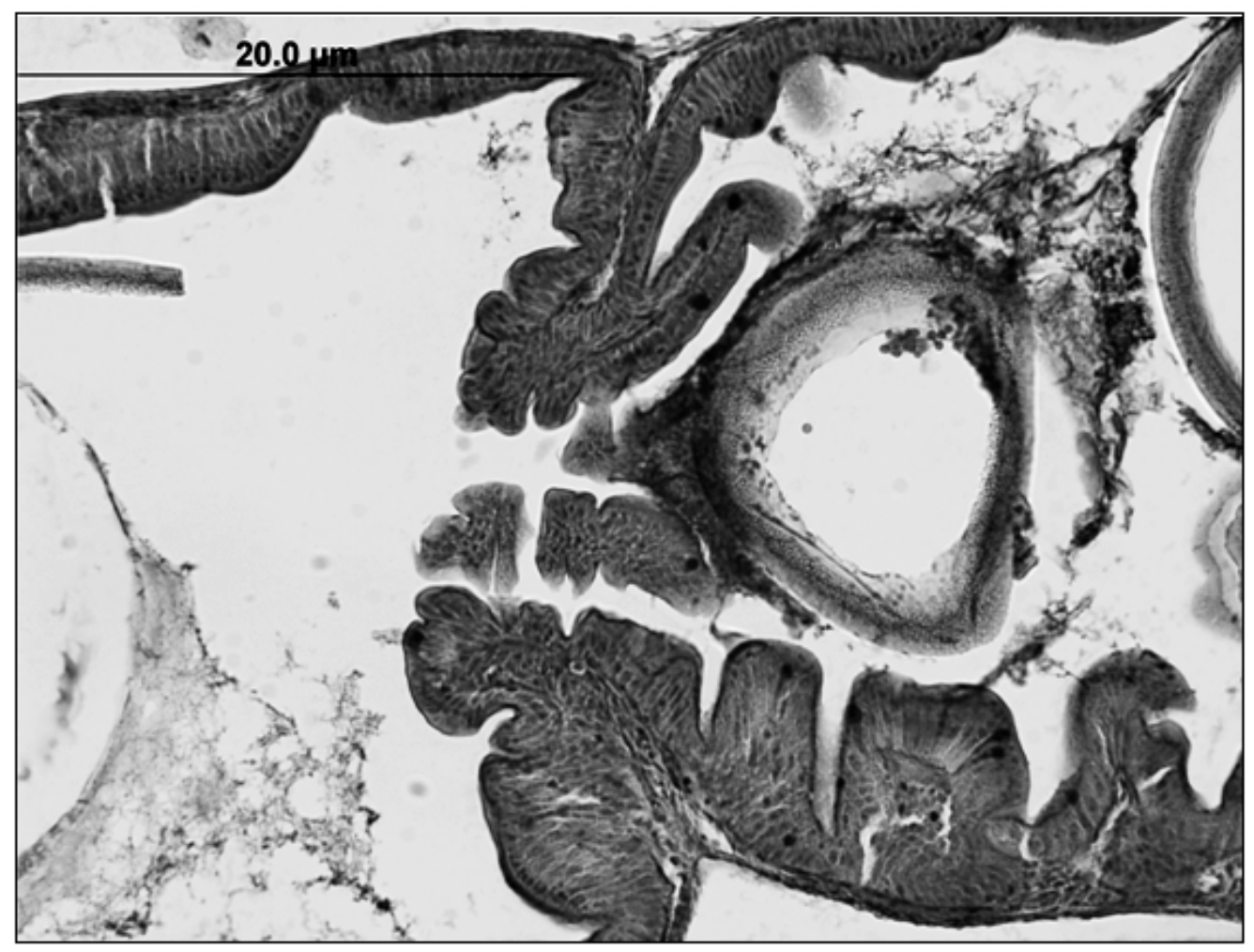

Figure 25 


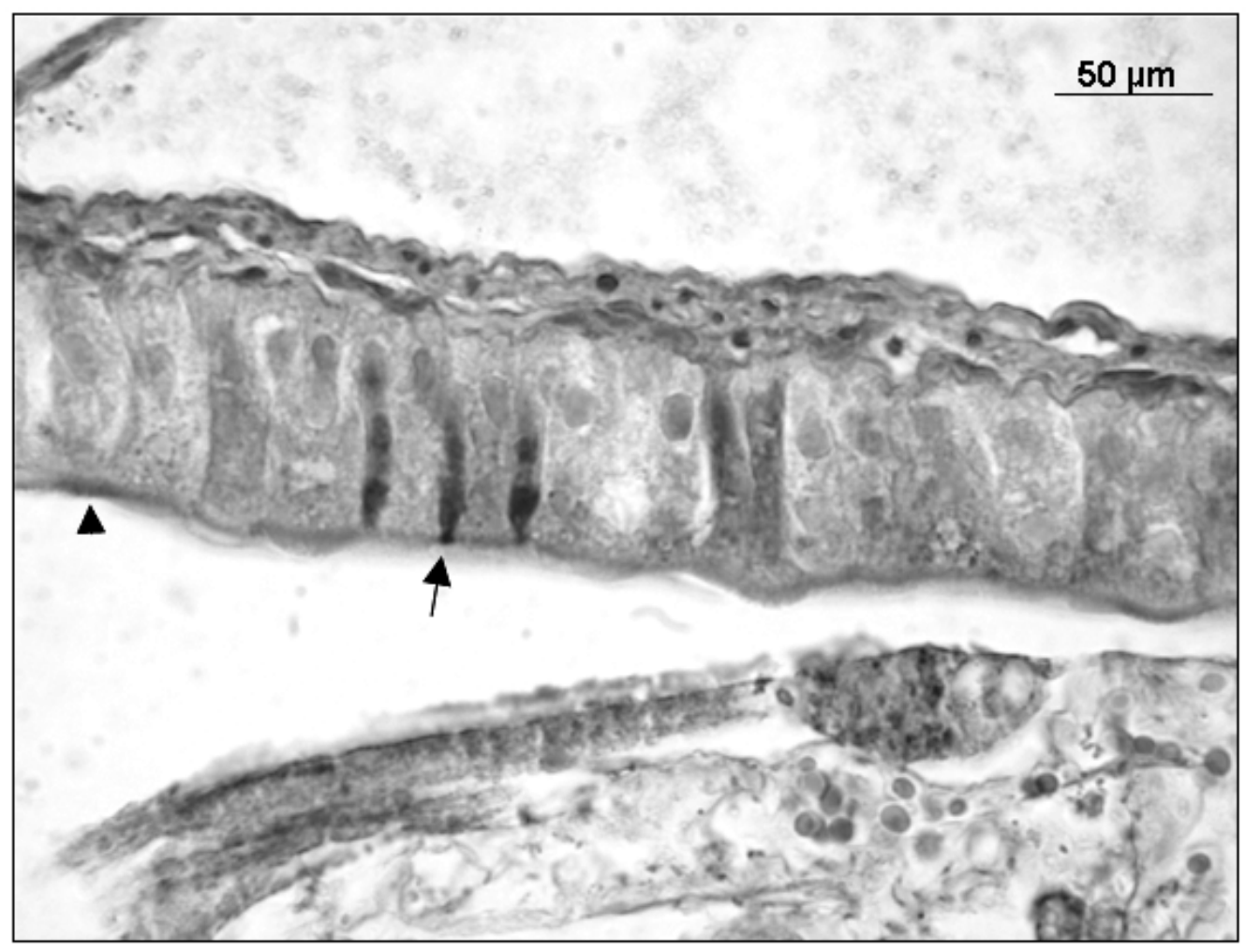

Figure 26 


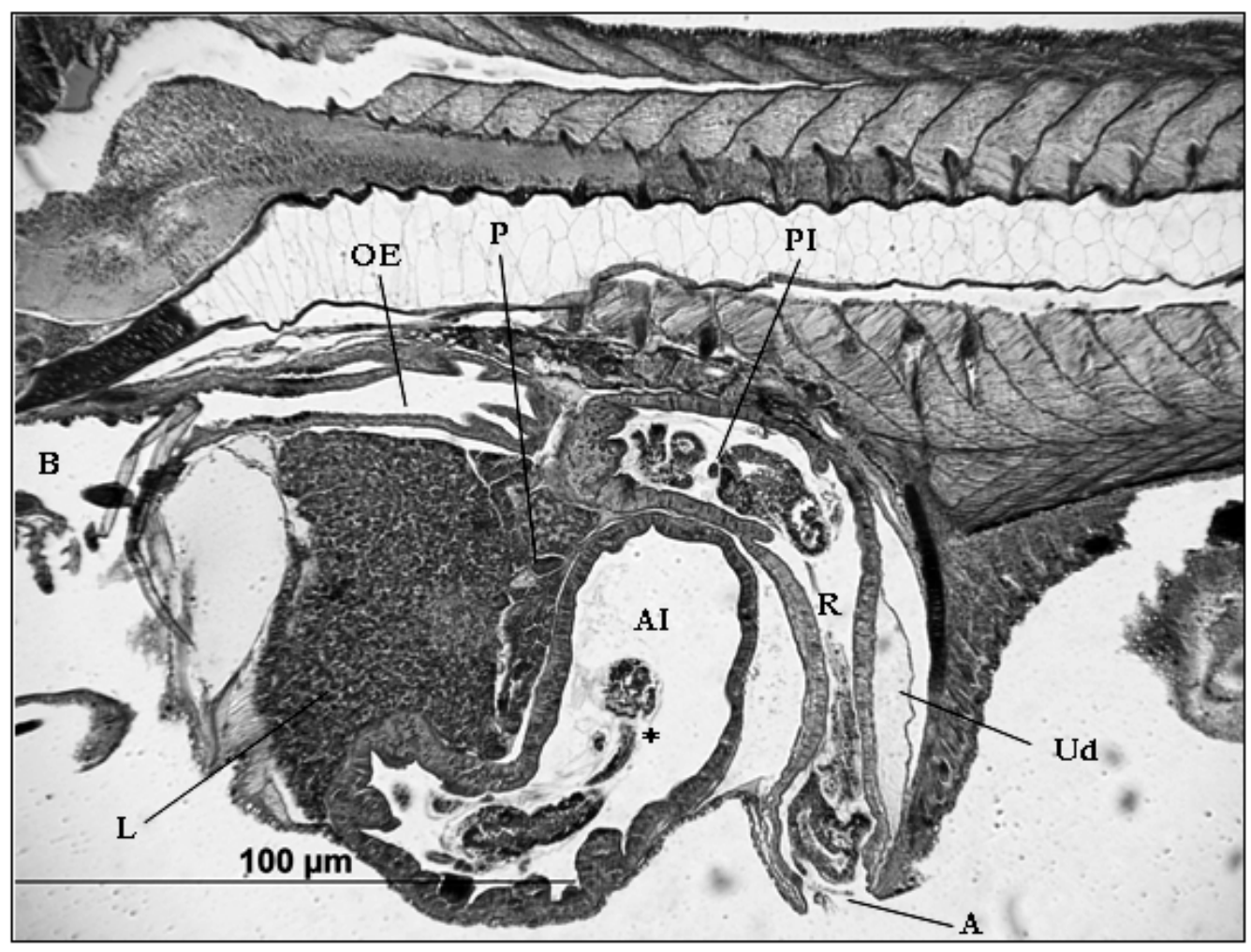

Figure 27 


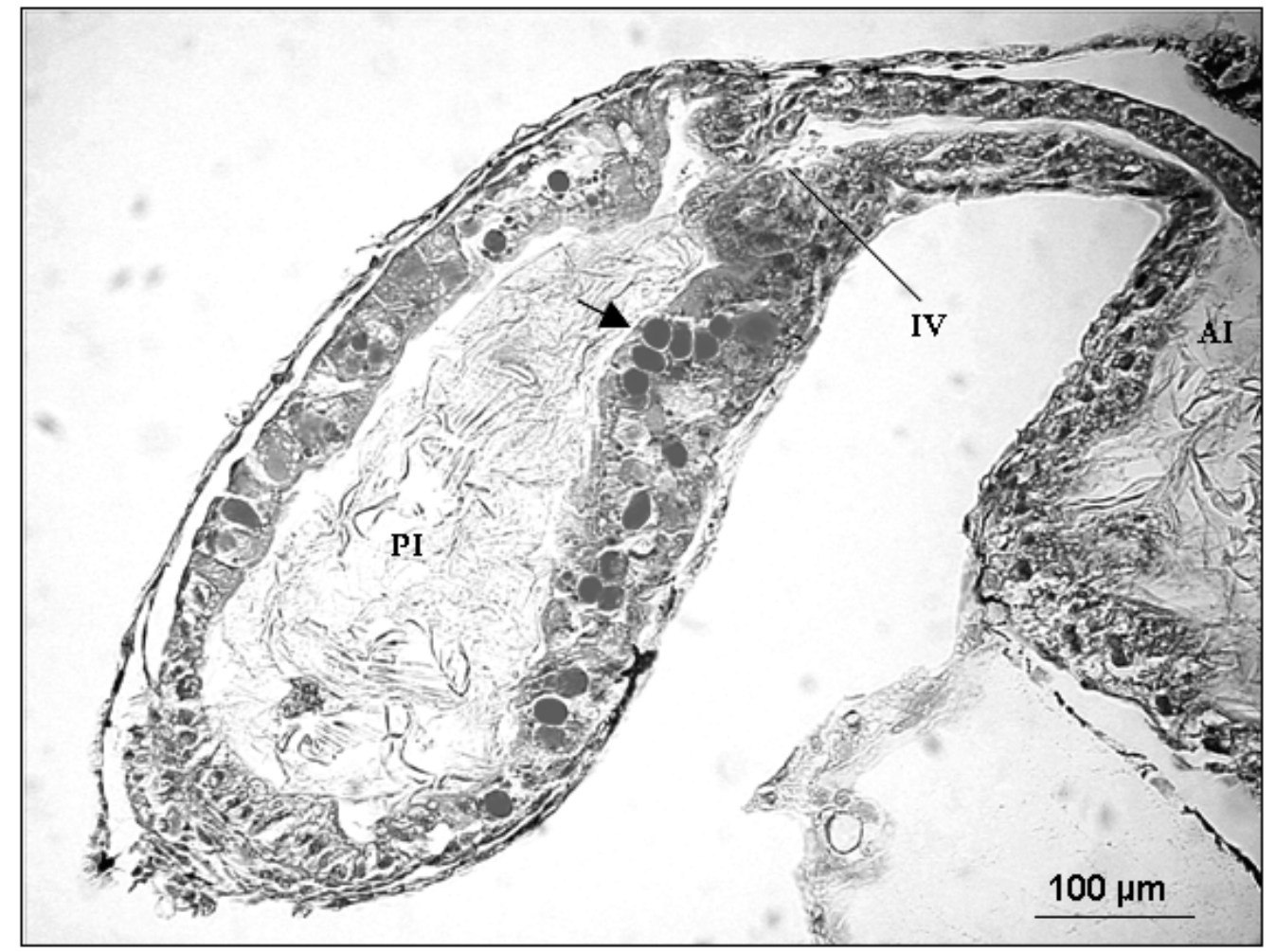

Figure 28 


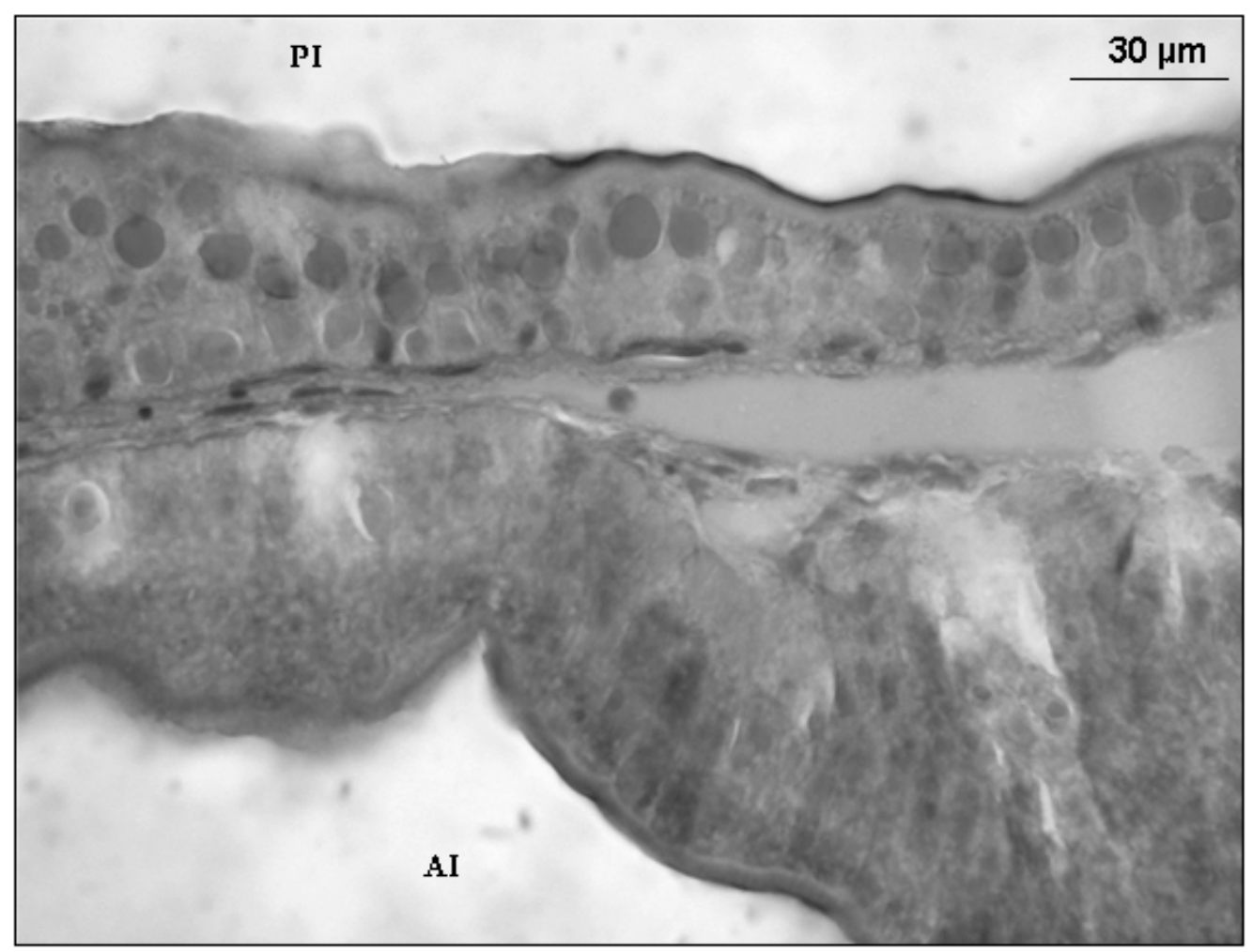

Figure 29 


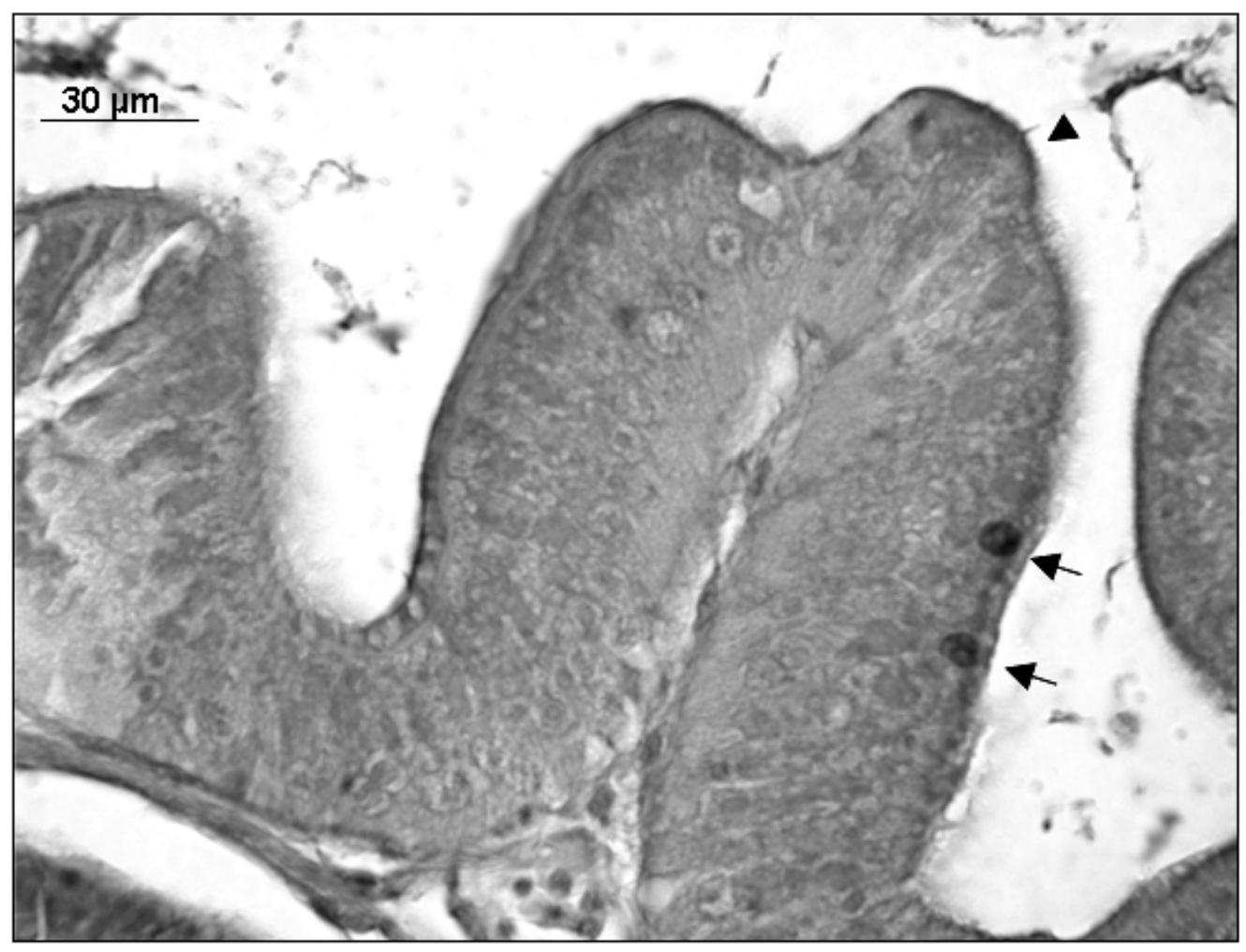

Figure 30 


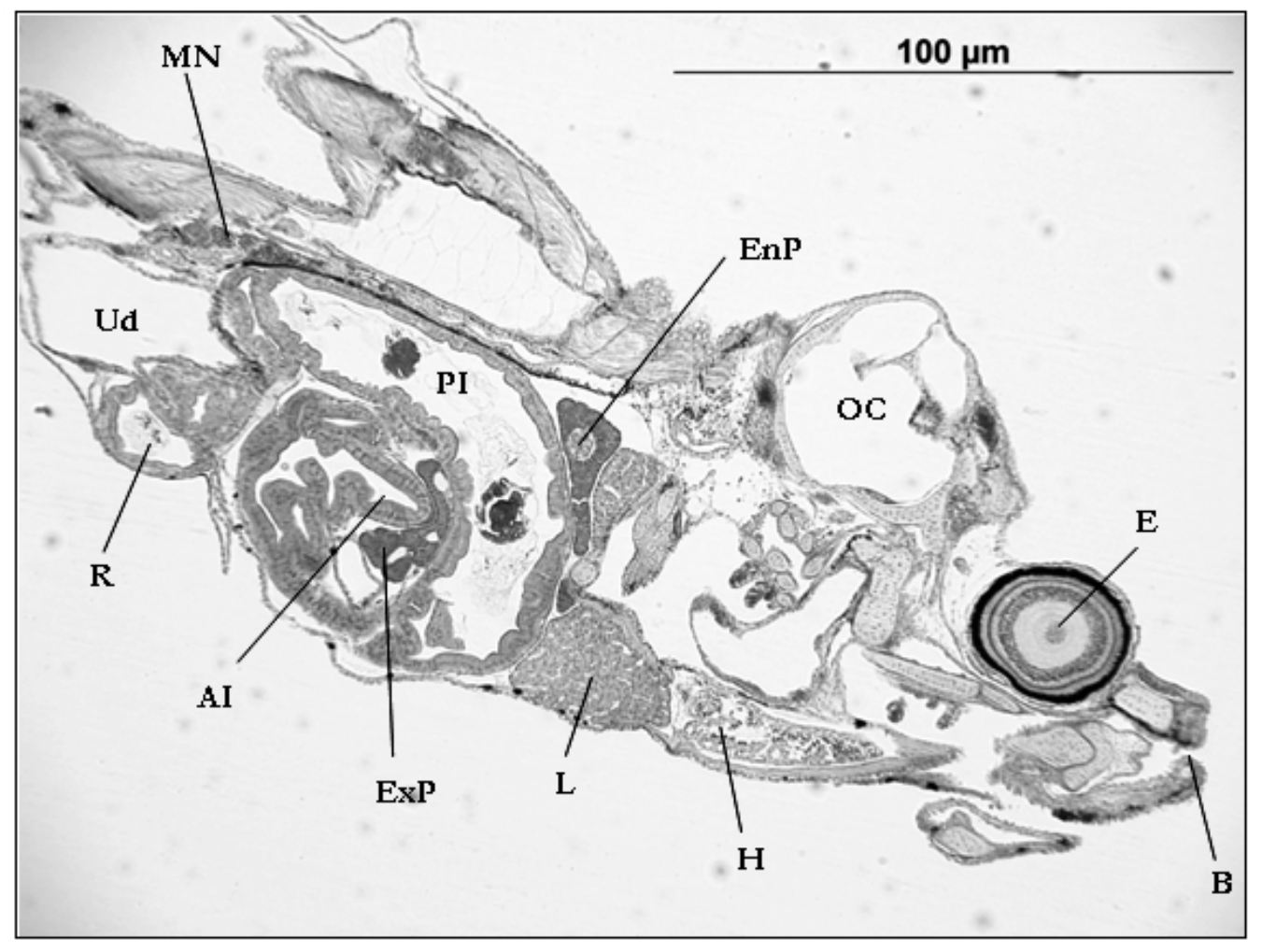

Figure 31 


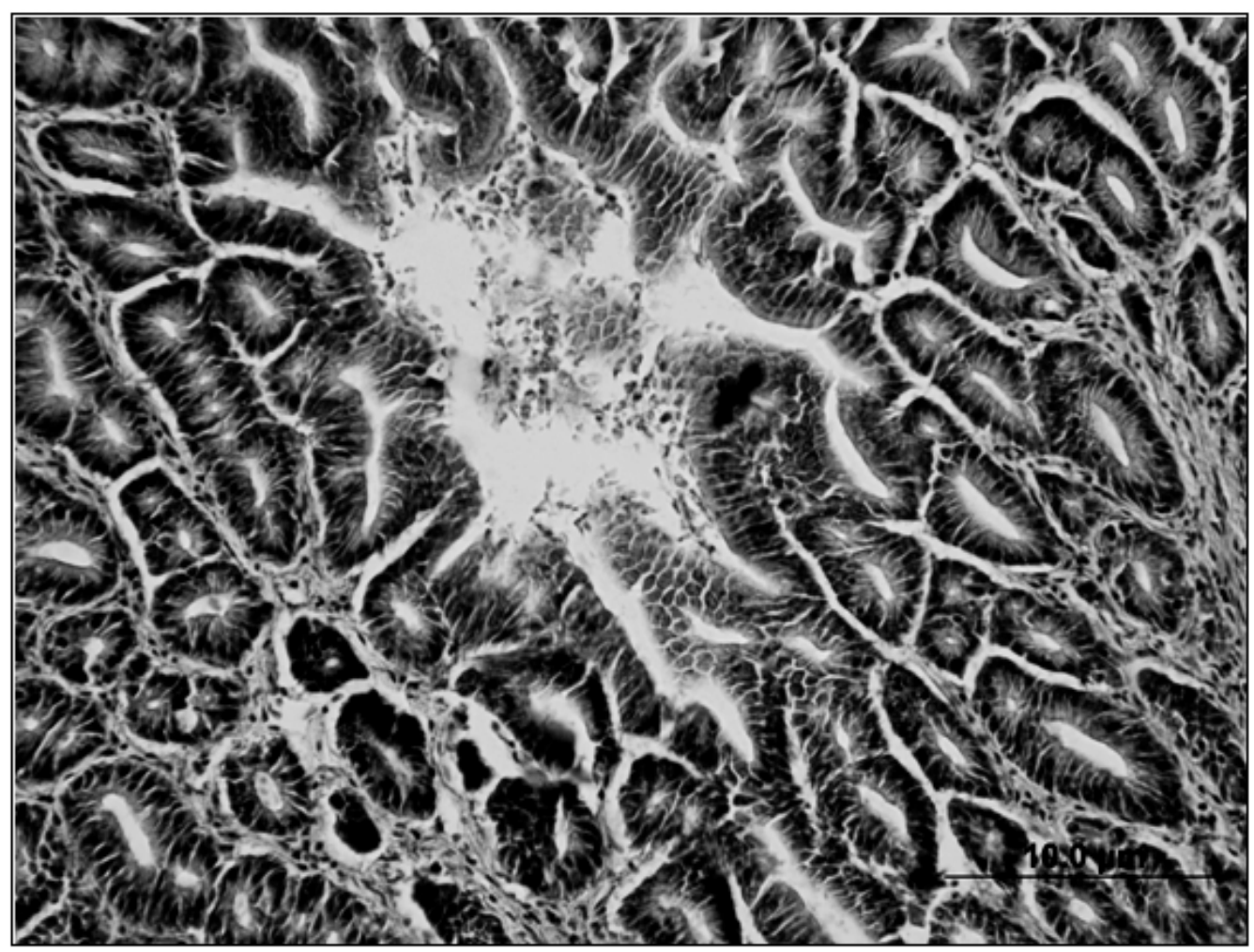

Figure 32 


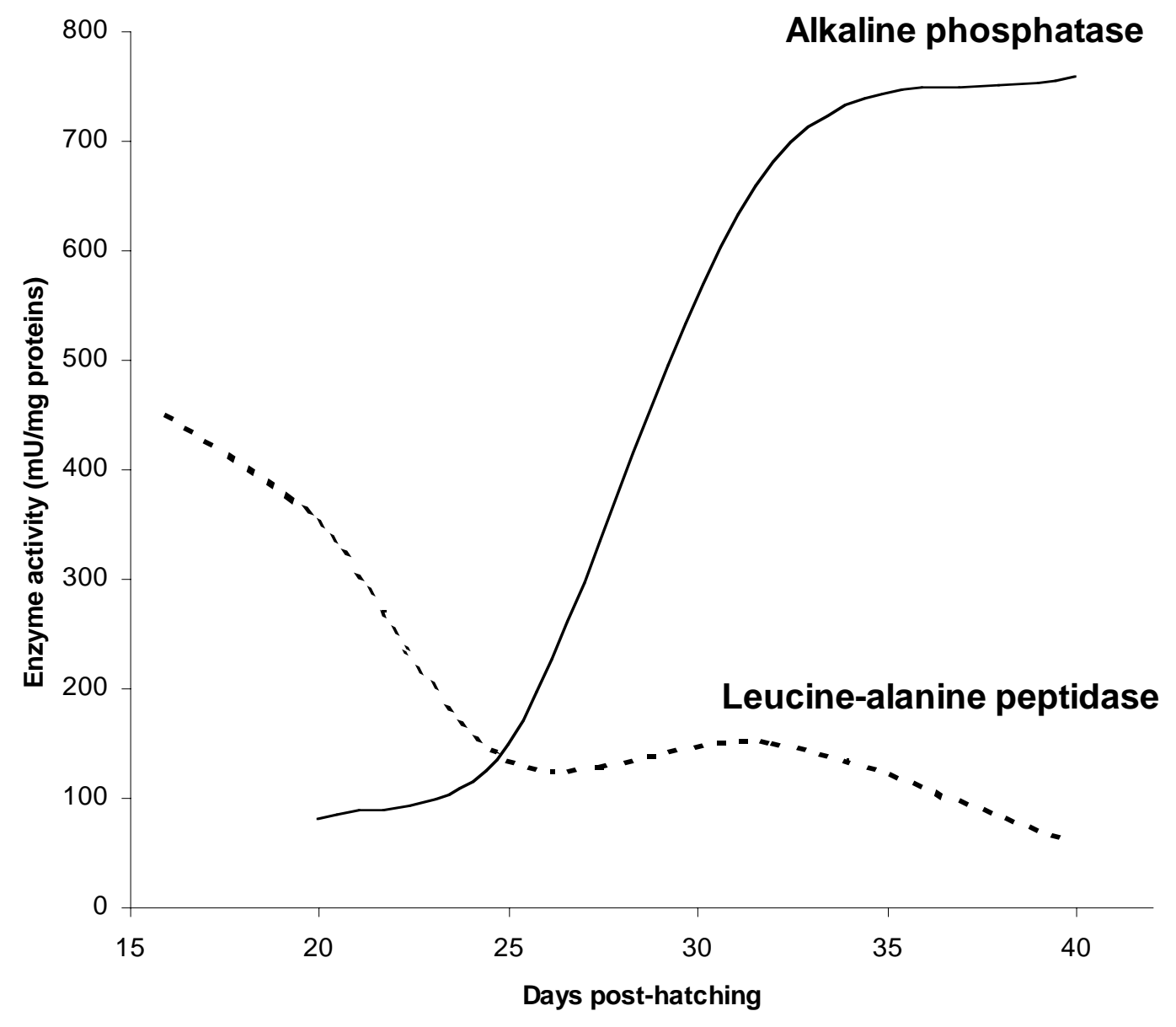

Figure 33 